\title{
Trace Gas Fluxes from Tropical Montane Forests of Southern Ecuador
}

\author{
Dissertation \\ zur Erlangung des Doktorgrades \\ der Fakultät für Forstwissenschaften und Waldökologie \\ der Georg-August-Universität Göttingen
}

vorgelegt von

Diplom Forstwirt

Guntars O. Martinson

geboren in Bonn Bad Godesberg, Deutschland

Göttingen, März 2011 
1. Gutachter: Prof. Dr. Edzo Veldkamp

2. Gutachter: Prof. Dr. Dirk Hölscher

Tag der mündlichen Prüfung: 28. März 2011 
"Fürchte dich nicht, ich bin mit dir; weiche nicht, denn ich bin dein Gott. Ich stärke dich, ich helfe dir auch, ich halte dich durch die rechte Hand meiner

Gerechtigkeit."

- Jesaja 41,10 - 


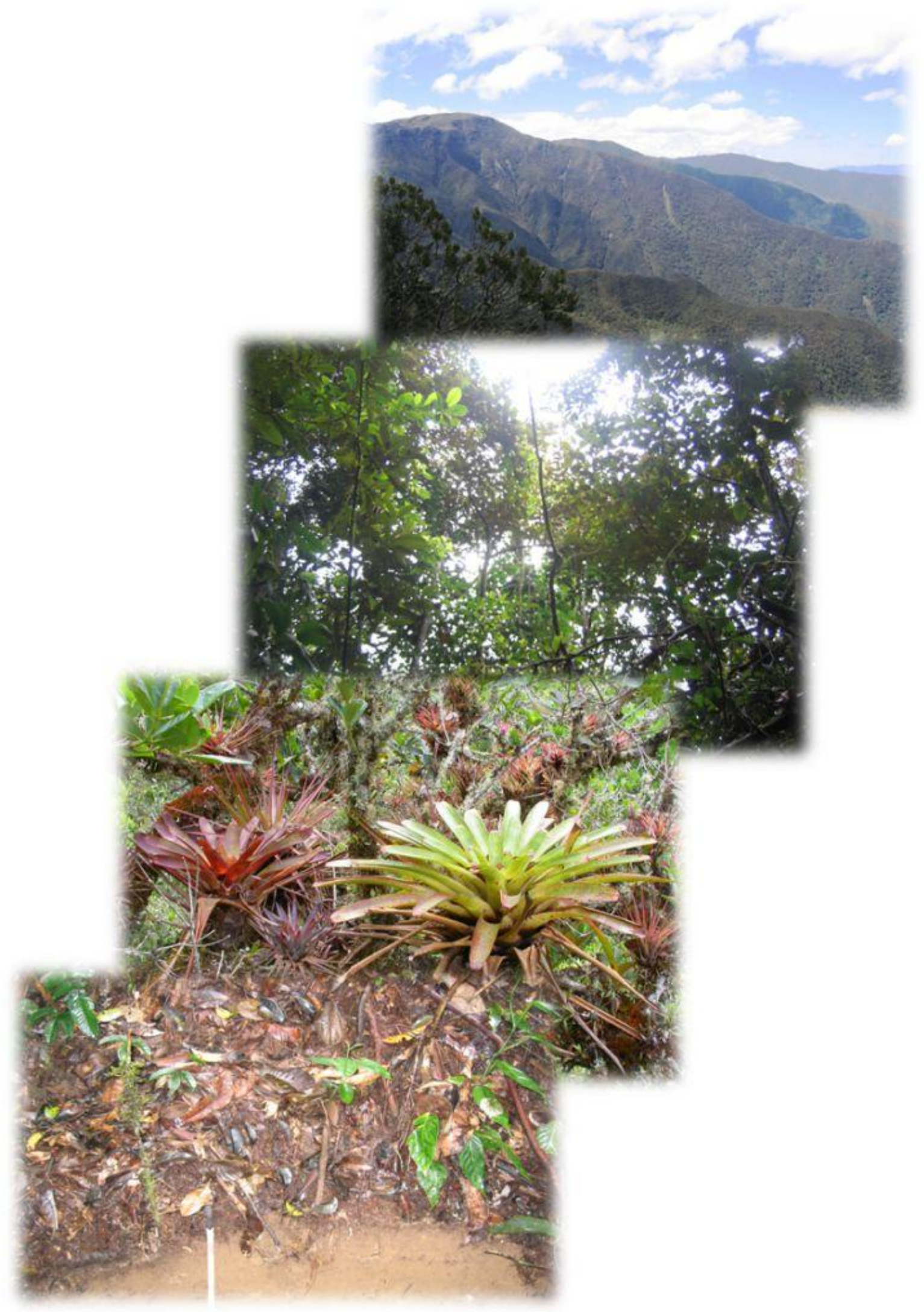

Photographs by G.O. Martinson and F. Werner 


\section{SUMMARY}

Methane $\left(\mathrm{CH}_{4}\right)$, nitrous oxide $\left(\mathrm{N}_{2} \mathrm{O}\right)$ and carbon dioxide $\left(\mathrm{CO}_{2}\right)$ are major greenhouse gases but their fluxes in tropical montane forests are hardly known. The distribution of known sources of $\mathrm{CH}_{4}$ (e.g. soil wetlands) fail to explain high $\mathrm{CH}_{4}$ concentrations above tropical montane forest canopies that were observed by space-borne measurements. Additionally, there are indications in recent literature that responses of soil $\mathrm{N}_{2} \mathrm{O}$ and $\mathrm{CO}_{2}$ fluxes to projected increases in nitrogen $(\mathrm{N})$ deposition in tropical forest areas can be predicted from nutrient limitation of vegetation growth. However, nutrient controls on $\mathrm{N}$ and $\mathrm{C}$ cycling processes have rarely been studied in tropical montane forests. This dissertation tries to elucidate (1) the role of tank bromeliads, growing in canopy wetlands of neotropical montane forests, as a potential source of $\mathrm{CH}_{4}$ that may help to explain the high $\mathrm{CH}_{4}$ concentrations above neotropical forest canopies, (2) nutrient controls on rates of soil $\mathrm{N}$ cycling and soil $\mathrm{N}_{2} \mathrm{O}$ fluxes and (3) nutrient controls on soil respiration in Andean neotropical montane forests of Southern Ecuador.

(1) $\mathrm{CH}_{4}$ fluxes from 167 tank bromeliads, a distinctive group of herbaceous water-impounding plants of three functional plant types with various sizes and from different strata of a moist tropical montane forest in the Ecuadorian Andes at 2100-m elevation were measured. Plant incubation chambers, ${ }^{13} \mathrm{C}$ stable isotope probing and molecular analysis techniques were used to show that tank bromeliads can have high rates of $\mathrm{CH}_{4}$ emissions. The gas is produced in their water-filled leaf axils (the pouch-like basal section) by a diverse community of methanogenic archaea. The dissolved $\mathrm{CH}_{4}$ in bromeliad tanks appears to be absorbed by foliar hairs (trichomes), diffused into aerenchyma and emitted through stomata into the atmosphere. This thesis estimates the $\mathrm{CH}_{4}$ source from the montane tropical forest at $3.6 \mathrm{~g} \mathrm{ha}^{-1} \mathrm{~d}^{-1}$, which is enough to compensate for atmospheric $\mathrm{CH}_{4}$ consumption in the soil at a rate of $3.1 \mathrm{~g} \mathrm{ha}^{-1} \mathrm{~d}^{-1}$. The neotropical forest source may be in the range of $1.2 \mathrm{Tg} \mathrm{yr}^{-1}$.

(2) Soil $\mathrm{N}_{2} \mathrm{O}$ fluxes and net rates of soil $\mathrm{N}$ cycling were measured in a factorial $\mathrm{NP}$ addition experiment (i.e. N, P, N+P, and control) (NUMEX) from January 2008 to September 2009 using vented static chambers, gas chromatographic and soil chemical analysis. The NUMEX-experiment was established in a stratified random design with 
three replicate plots per treatment and 20-m x 20-m area each plot at three sites along an altitudinal gradient in the Ecuadorian Andes $(1000-\mathrm{m}, 2000-\mathrm{m}$ and $3000-\mathrm{m}$ elevation). Fertilizers were applied at the rates of $50 \mathrm{~kg} \mathrm{~N} \mathrm{ha}^{-1} \mathrm{yr}^{-1}$ (in the form of urea) and $10 \mathrm{~kg} \mathrm{P} \mathrm{ha}^{-1} \mathrm{yr}^{-1}$ (in the form of $\mathrm{NaH}_{2} \mathrm{PO}_{4} \cdot 2 \mathrm{H}_{2} \mathrm{O}$ with analytical grade quality) split in two equal applications per year starting in February 2008. At the $2000-\mathrm{m}$ and $3000-\mathrm{m}$ elevations, where an organic layer was present and vegetation growth did not respond to nutrient additions, net rates of soil $\mathrm{N}$ cycling and $\mathrm{N}_{2} \mathrm{O}$ emissions started to increase following $\mathrm{N}$ and $\mathrm{N}+\mathrm{P}$ addition after the third nutrient application in 2009 but the effects were less pronounced at the 3000-m elevation. At 1000-m elevation, where an organic layer was absent and vegetation growth did not respond to nutrient additions, net rates of soil $\mathrm{N}$ cycling and $\mathrm{N}_{2} \mathrm{O}$ emissions started to increase following $\mathrm{N}$ and $\mathrm{N}+\mathrm{P}$ addition after the second nutrient application in 2008. Addition of $\mathrm{P}$ alone had no effect on net rates of soil $\mathrm{N}$ cycling and $\mathrm{N}_{2} \mathrm{O}$ emissions at any elevation.

(3) Soil respiration and litterfall was measured in the NUMEX-experimental plots from January 2008 to September 2009 using vented static chambers, gas chromatographic analysis, litter traps and leaf chemical analysis. At the 2000-m and 3000-m elevations, where an organic layer was present and vegetation growth did not respond to nutrient additions, soil respiration increased following $\mathrm{N}$ addition which may be caused by a stimulation of microbial activity in the organic layer, leading to an increase of heterotrophic respiration. At the 1000-m elevation, where an organic layer was absent and vegetation growth did not respond to nutrient additions, soil respiration did not respond to nutrient addition.

The results of this thesis show that $\mathrm{CH}_{4}$ emissions from tank bromeliads and probably other types of phytotelmata in "canopy wetlands" may help to explain the unidentified $\mathrm{CH}_{4}$ source strength of neotropical forests. Secondly, the response of net rates of soil $\mathrm{N}$ cycling, soil $\mathrm{N}_{2} \mathrm{O}$ fluxes and soil respiration to $\mathrm{N}$ and $\mathrm{P}$ additions in tropical montane forests depend mainly on the amount of nutrient added and on the soil nutrient status which may primarily be controlled by the presence or absence of an organic layer and may be independent from nutrient limitation of vegetation. Finally, projected increases in atmospheric $\mathrm{N}$ deposition in tropical regions may induce immediate losses of $\mathrm{N}$ and $\mathrm{C}$ through soil $\mathrm{N}_{2} \mathrm{O}$ and $\mathrm{CO}_{2}$ emissions from tropical montane forest ecosystems. 


\section{ZUSAMMENFASSUNG}

Methan $\left(\mathrm{CH}_{4}\right)$, Lachgas $\left(\mathrm{N}_{2} \mathrm{O}\right)$ und Kohlenstoffdioxid $\left(\mathrm{CO}_{2}\right)$ sind wichtige Treibhausgase. Ihre Produktion und Aufnahme in tropischen Bergregenwäldern sind gänzlich unbekannt. Über den tropischen Bergregenwäldern wurden vor kurzem erhöhte $\mathrm{CH}_{4}$ Konzentrationen anhand von Satellitenmessungen festgestellt. Diese erhöhten $\mathrm{CH}_{4}$ Konzentrationen können allerdings nicht mit der Verteilung bekannter $\mathrm{CH}_{4}$-Quellen (Bodenfeuchtgebiete) erklärt werden. Des Weiteren gibt es Hinweise, dass zukünftige Veränderungen natürlicher Boden- $\mathrm{N}_{2} \mathrm{O}$ und $-\mathrm{CO}_{2}$ Emissionen infolge zunehmender Stickstoff (N)- Depositionen in tropischen Regenwaldregionen durch die Identifikation der Nährstofflimitierung des Pflanzenwachstums vorhergesagt werden können. Die Beeinflussung und Steuerung von Boden- $\mathrm{N}_{2} \mathrm{O}$ und $-\mathrm{CO}_{2}$ Emissionen durch die Nährstoffverfügbarkeit wurden allerdings noch nicht in tropischen Bergregenwäldern untersucht. Diese Dissertation versucht (1) potentielle $\mathrm{CH}_{4}$ Emissionen aus Tankbromelien, die in den Baumkronen neotropischer Bergregenwälder wachsen, festzustellen und $\mathrm{zu}$ quantifizieren und ihren Beitrag $\mathrm{zu}$ den erhöhten $\mathrm{CH}_{4}$ Konzentration über den tropischen Bergregenwäldern abzuschätzen, (2) die Beeinflussung und Steuerung des Bodenstickstoffkreislaufs und der Boden- $\mathrm{N}_{2} \mathrm{O}$ Emissionen durch die Nährstoffverfügbarkeit in tropischen Bergregenwäldern zu untersuchen und (3) die Beeinflussung und Steuerung der Bodenatmung durch die Nährstoffverfügbarkeit in den tropischen Bergregenwäldern der Anden im Süden Ekuadors zu untersuchen.

(1) Die $\mathrm{CH}_{4}$-Flüsse von 167 Tankbromelien wurden in den Bergregenwäldern der ekuadorianischen Anden auf 2100 m Höhe gemessen. Tank Bromelien gehören zu der Familie der Bromeliengewächsen (Bromeliaceae). Für die Messungen wurden die 167 Tankbromelien aus drei verschiedenen funktionellen Pflanzengruppen ausgesucht. Mithilfe von Inkubationskammern, ${ }^{13} \mathrm{C}$ Markierungsversuchen und molekularen Analysen konnte gezeigt werden, dass Tankbromelien erhebliche Mengen an $\mathrm{CH}_{4}$ 
emittieren können. Das $\mathrm{CH}_{4}$ wird in den wassergefüllten Blattachseln der Bromelien durch eine diverse Gemeinschaft methanogener Archaean produziert. Wir vermuten, dass das im Wasser gelöste $\mathrm{CH}_{4}$ von Blatttrichomen absorbiert wird. Von dort gelangt es in das Aerenchym der Blätter und wird schließlich über die Stomata in die Atmosphäre emittiert. Diese Dissertation schätzt diese $\mathrm{CH}_{4}$-Quelle in den Bergregenwäldern Ekuadors auf circa $3.6 \mathrm{~g} \mathrm{ha}^{-1} \mathrm{~d}^{-1}$. Diese Quellstärke ist groß genug, um die $\mathrm{CH}_{4}$-Aufnahme des Bodens, die bei circa $3.1 \mathrm{~g} \mathrm{ha}^{-1} \mathrm{~d}^{-1}$ liegt, zu kompensieren. Die extrapolierte GesamtQuellstärke der neotropischen Wälder beläuft sich auf 1.2 $\mathrm{Tg}_{\mathrm{yr}}{ }^{-1}$.

(2) Boden- $\mathrm{N}_{2} \mathrm{O}$ Flüsse und Boden-N-Umsatzraten wurden in einem mehrfaktoriellem N und P Düngerexperiment (N, P, N+P und Kontrolle) (NUMEX) mithilfe von statischen, belüfteten Bodengashauben, gas-chromatografischer und bodenchemischer Analysen von Januar 2008 bis September 2009 gemessen. Das NUMEX-Experiment wurde in einer zufälligen und mehrschichtigen Versuchsanordnung mit jeweils drei Wiederholungen (Plotgröße: $20 \mathrm{~m}$ x $20 \mathrm{~m}$ ) entlang eines Höhengradienten auf drei verschiedenen Höhenstufen (1000 m, 2000 m und 3000 m) in den ekuadorianischen Bergregenwäldern aufgebaut und durchgeführt. Der N- (50 kg N ha-1 $\mathrm{yr}^{-1}$, Urea) und P-Dünger (10 kg P ha-1 $\mathrm{yr}^{-1}, \mathrm{NaH}_{2} \mathrm{PO}_{4} \cdot 2 \mathrm{H}_{2} \mathrm{O}$ pro analysi) wurde in gleichen Mengen zweimal pro Jahr in den jeweiligen Versuchsflächen per Hand aufgetragen. Der Düngerversuch startete im Februar 2008. Auf 2000 m und 3000 m Höhe, wo eine organische Auflage existierte und das Pflanzenwachstum nicht auf eine Düngerzugabe reagierte, stiegen die Nettoumsatzraten des Boden- $\mathrm{N}$ und die $\mathrm{N}_{2} \mathrm{O}$ Emissionen infolge der N- und N+P-Zugabe nach der dritten Düngerzugabe im zweiten Jahr an. Auf 3000 m Höhe fielen die Effekte allerdings geringer aus. Auf 1000 m Höhe, wo es keine organische Auflage gab und das Pflanzenwachstum ebenfalls nicht auf eine Düngerzugabe reagierte, stiegen die Nettoumsatzraten des Boden- $\mathrm{N}$ und die $\mathrm{N}_{2} \mathrm{O}$ Emissionen infolge der N- und N+P-Zugabe schon nach der zweiten Düngerzugabe im ersten Jahr an. Die Zugabe von P zeigte keinen Effekt auf allen Höhenstufen.

(1) Die Bodenatmung und der Streufall wurden im NUMEX-Experiment von Januar 2008 bis September 2009 mithilfe von statischen, belüfteten Bodengashauben, Laubstreufängern und gas-chromatografischer und pflanzenchemischer Analysen gemessen. Auf 2000 m und 3000 m Höhe, wo eine organische Auflage existierte und das Pflanzenwachstum nicht auf eine Düngerzugabe reagierte, stieg die Bodenatmung 
infolge der N-Zugabe an. Der Grund hierfür lag wahrscheinlich an einer Stimulierung der mikrobiellen Aktivität in der organischen Auflage infolge N-Zugabe, was zu einer Erhöhung der heterotrophen Respiration führte. Auf $1000 \mathrm{~m}$ Höhe, wo es keine organische Auflage gab und das Pflanzenwachstum ebenfalls nicht auf eine Düngerzugabe reagierte, gab es keine Düngereffekte auf die Bodenatmung.

Die Ergebnisse dieser Dissertation zeigen, dass die $\mathrm{CH}_{4}$-Emissionen aus Tankbromelien und wahrscheinlich auch aus andere Arten von Phytotelmen, die in den Feuchtgebieten von Baumkronen wachsen und in ihren Blattachseln bzw. anderen Wasserspeichern das Regenwasser auffangen, einen bedeutenden Beitrag zur Aufklärung der erhöhten atmosphärischen $\mathrm{CH}_{4}$-Konzentrationen über den tropischen Bergregenwäldern leisten. Des Weiteren zeigen die N- und P-Düngereffekte auf die Nettoumsatzraten des Boden- $\mathrm{N}$, die $\mathrm{N}_{2} \mathrm{O}$ Emissionen und die Bodenatmung, dass diese Effekte unabhängig von der Nährstofflimiterung der Pflanzen in erster Linie von dem Vorhandensein einer organischen Bodenauflage abhängig sind. Zuletzt, zeigen die Ergebnisse dieser Dissertation, dass zukünftige, erhöhte atmosphärische NDepositionen in tropischen Gebieten in der Lage sein könnten, kurzfristige Boden-C und - $\mathrm{N}$ Verluste infolge steigender $\mathrm{N}_{2} \mathrm{O}$ und $\mathrm{CO}_{2}$ Emissionen, herbeizuführen. 


\section{TABLE OF CONTENTS}

Summary

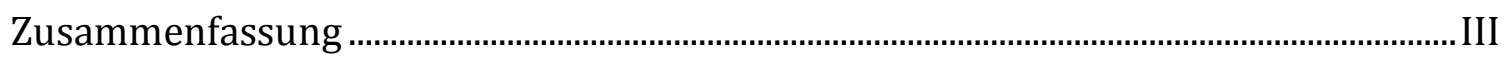

\section{CHAPTER I}

\section{GENERAL INTRODUCTION}

1 Soil trace gas fluxes in tropical montane forests...................................................................

2 "Missing" sources of methane and nitrous oxide in tropical forests................................... 3

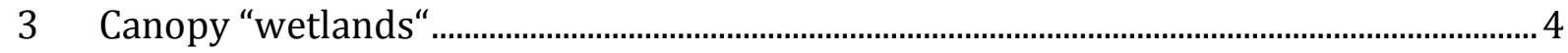

4 Nutrient controls on soil respiration and soil $\mathrm{N}_{2} \mathrm{O}$ fluxes in tropical montane forests ............................................................................................................. 5

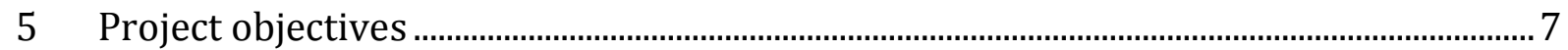

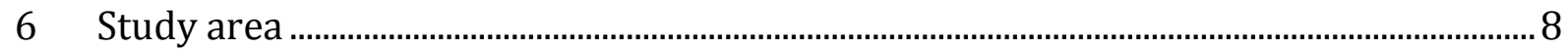

7 Experimental design of the nutrient manipulation experiment (NUMEX) ...................10

8 Set up for investigation of methane emissions from tank bromeliads............................. 12

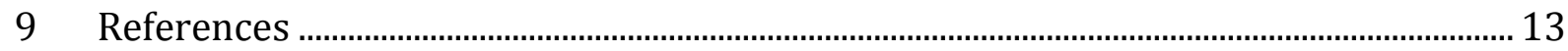

\section{CHAPTER II}

METHANE EMISSIONS FROM TANK BROMELIADS IN NEOTROPICAL FORESTS

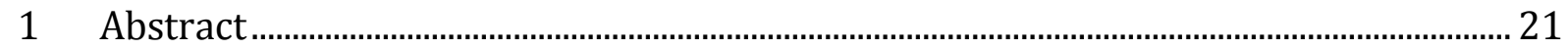

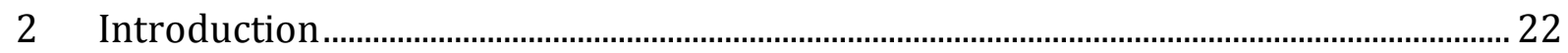

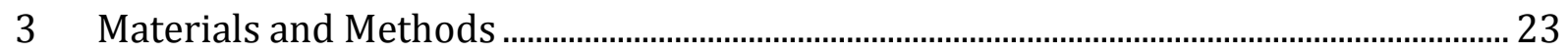

3.1 Sampling design .............................................................................................................. 23 
3.2 Methane flux measurement of bromeliads

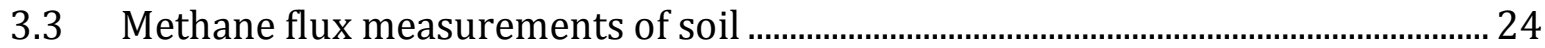

3.4 Methane flux measurement of bromeliad leaves........................................................ 24

3.5 Methane concentration measurement of bromeliad tank water .............................. 25

3.6 Molecular analysis of methanogenic communities.................................................... 26

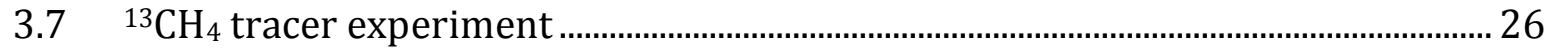

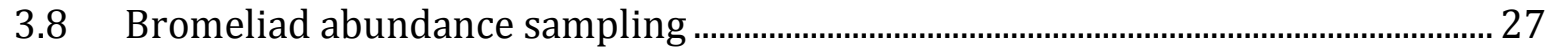

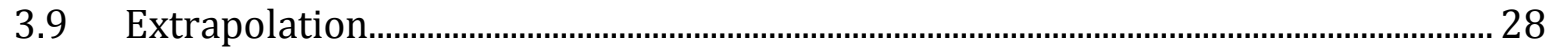

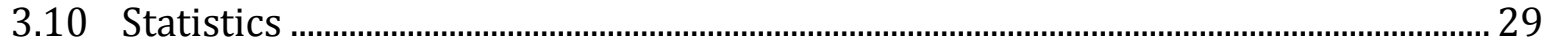

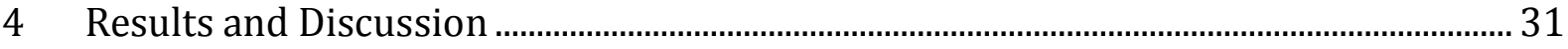

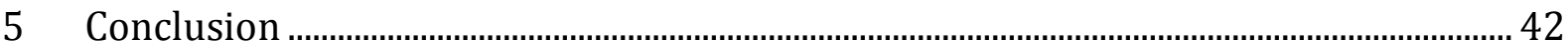

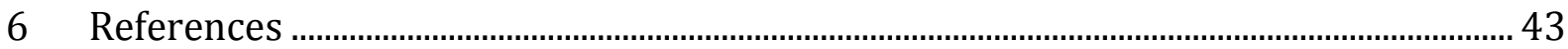

\section{CHAPTER III}

RESPONSES OF NITROUS OXIDE AND SOIL NITROGEN CYCLING TO NUTRIENT ADDITIONS IN MONTANE FORESTS ALONG AN ELEVATION GRADIENT IN SOUTHERN ECUADOR

1 Abstract

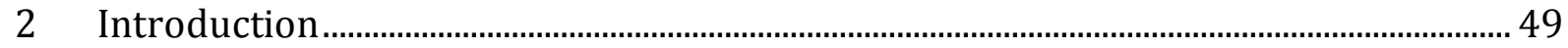

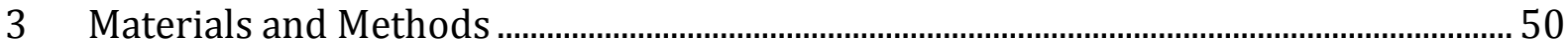

3.1 Study area

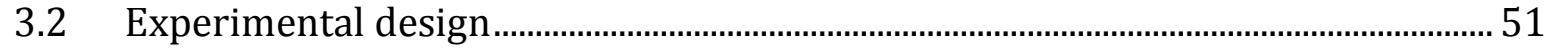

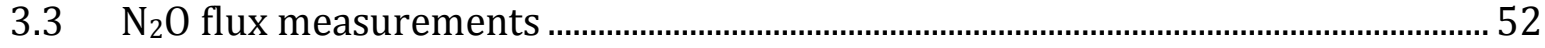

3.4 Soil mineral N, soil moisture and net rates of soil N cycling ...................................... 55

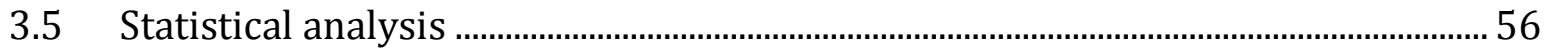

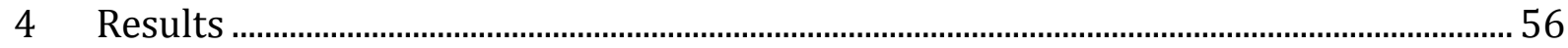


4.1 Soil temperature, moisture, mineral N, N-cycling rates

and $\mathrm{N}_{2} \mathrm{O}$ fluxes from control forest soils

4.2 Nutrient addition effects on soil mineral $\mathrm{N}$ and net rates of soil $\mathrm{N}$ cycling 60

4.3 Nutrient addition effects on soil $\mathrm{N}_{2} \mathrm{O}$ fluxes.

5 Discussion 65

5.1 Soil $\mathrm{N}$ cycle and $\mathrm{N}_{2} \mathrm{O}$ fluxes from control plots 65

5.2 Nutrient controls of soil $\mathrm{N}$ cycle and $\mathrm{N}_{2} \mathrm{O}$ fluxes at 1000 m elevation 66

5.3 Nutrient controls of soil $\mathrm{N}$ cycle and $\mathrm{N}_{2} \mathrm{O}$ fluxes at 2000 and $3000 \mathrm{~m}$ elevation

5.4 Soil nutrient status of tropical montane forests and its implications for increasing Nitrogen deposition

References 70

\section{CHAPTER IV}

RESPONSE OF SOIL RESPIRATION TO NUTRIENT ADDITIONS IN MONTANE FORESTS ALONG AN ELEVATION GRADIENT IN SOUTHERN ECUADOR

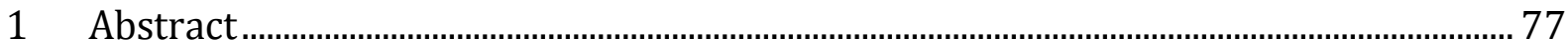

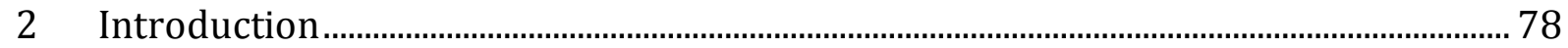

3 Materials and methods ........................................................................................................... 80

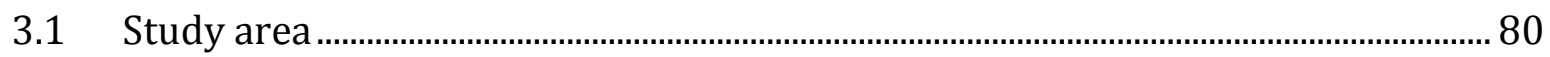

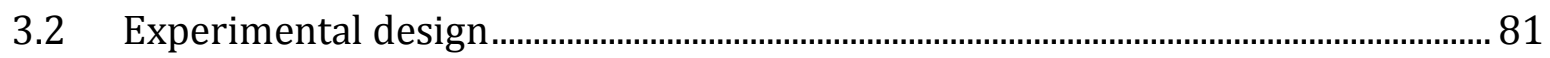

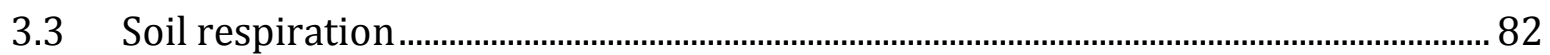

3.4 Litterfall and litter nutrients and nutrient use efficiencies ....................................... 83

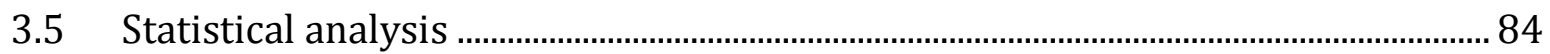

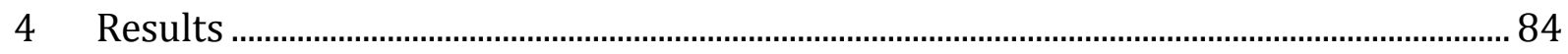

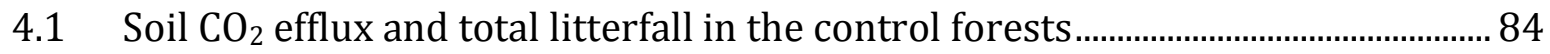

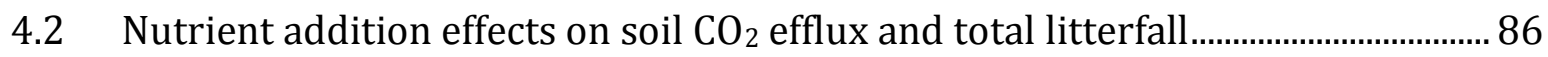


5.1 Soil $\mathrm{CO}_{2}$ efflux and total litterfall in control forest plots ............................................ 92

5.2 Nutrient controls on soil respiration and leaf litter production ...............................93

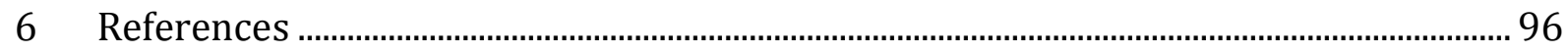

\section{CHAPTER V}

\section{SYNTHESIS}

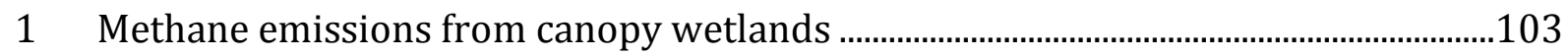

2 Nutrient controls on biogeochemical cycles

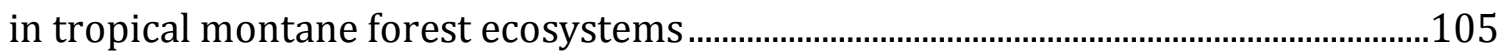

3 Nutrient controls on soil nitrogen cycling and nitrous oxide fluxes ............................106

$4 \quad$ Nutrient controls on soil respiration ............................................................................. 108

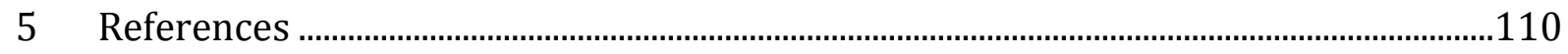

Declaration of Originality and Certificate of Ownership .................................................... XIV

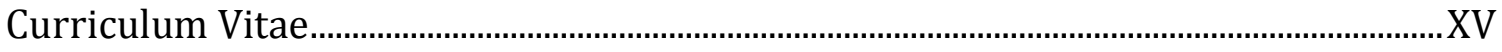




\section{LIST OF FIGURES}

\section{CHAPTER I}

Figure 1. Location of the three study sites in the tropical montane forests of Southern

Ecuador

Figure 2. Forest vegetation at the three study sites.............................................................. 10

Figure 3. NUtrient Manipulation EXperiment (NUMEX). .................................................... 11

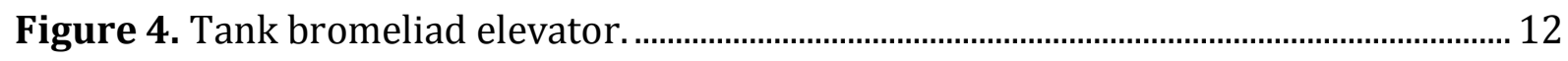

\section{CHAPTER II}

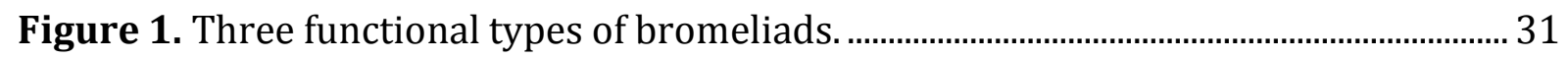

Figure 2. Leaf litter and organic debris in the leaf axil of a tank bromeliad ......................... 32

Figure 3. Methane emissions from the three functional types of bromeliads in relation to

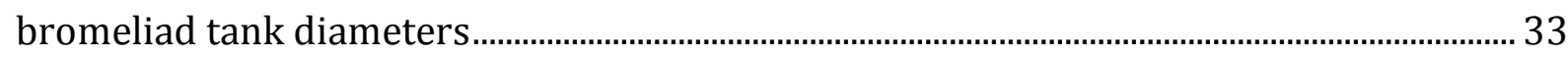

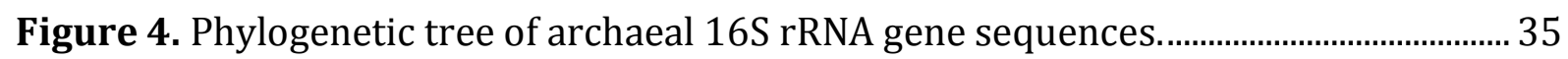




\section{CHAPTER III}

Figure 1. (a) Mean ( \pm SE, $n=3$ ) soil temperature (b) and water-filled pore space (WFPS) (b) at the top 0.05-m soil depth in control plots at the 1000-m (»), 2000-m (a) and 3000m sites $(\Delta)$ 57

Figure 2. Mean ( $\pm \mathrm{SE}, n=3$ ) soil extractable $\mathrm{NH}_{4}{ }^{+}$of the top 5-cm soil depth at the (a) 1000-m, (b) 2000-m, and (c) 3000-m sites in the control ( $\diamond$ ), N-addition ( $\square$ ), P-addition $(\bullet)$ and N+P-addition $(\Delta)$ plots. Red vertical lines indicate nutrient applications. 58

Figure 3. Mean ( $\pm \mathrm{SE}, n=3$ ) soil extractable $\mathrm{NO}_{3}$ - of the top 5 -cm soil depth the (a) 1000-m (b) 2000-m and (c) 3000-m sites in the control ( $\diamond$ ), N-addition ( $\square$ ), P-addition $(\bullet)$ and $\mathrm{N}+\mathrm{P}$-addition $(\Delta)$ plots. Red vertical lines indicate nutrient applications. 59

Figure 4. Mean ( $\pm \mathrm{SE}, n=3$ ) $\mathrm{N}_{2} \mathrm{O}$ fluxes at the (a) $1000-\mathrm{m}$, (b) 2000-m, and (c) 3000-m sites in the control $(\diamond), \mathrm{N}$-addition $(\square)$, P-addition $(\bullet)$ and $N+P$-addition $(\Delta)$ plots. Red vertical lines indicate nutrient applications.

Figure 5. Average soil $\mathrm{N}_{2} \mathrm{O}$ fluxes $\left(\mathrm{kg} \mathrm{N}\right.$ ha $^{-1} \mathrm{yr}^{-1}$, mean $\pm \mathrm{SE}, n=3$ with 10 and 7 monthly measurements for 2008 and for 2009) in the control, N-addition, P-addition and N+Paddition plots of the forest sites across the elevation gradient in 2008 (a) and 2009 (b). 


\section{CHAPTER IV}

Figure 1. Soil temperature and water-filled pore space (WFPS) at the top 0.05-m soil depth in control plots at the 1000-m, 2000-m and 3000-m sites. 85

Figure 2. Mean soil $\mathrm{CO}_{2}$ efflux at the 1000-m, 2000-m and 3000-m sites..

Figure 3. Mean normalized ratio of soil $\mathrm{CO}_{2}$ efflux to monthly total litterfall at the 1000 m, 2000-m and 3000-m sites. 88

Figure 4. Total litterfall at the 1000-m, 2000-m and 3000-m sites after two nutrient applications in the control and nutrient addition plots in 2008. 89

Figure 5. Annual soil $\mathrm{CO}_{2}$ efflux at the 1000-m, 2000-m and 3000-m sites after two nutrient applications in the control and nutrient addition plots in 2008. 89

Figure 6. $\mathrm{N}$ and $\mathrm{P}$ use efficiency and monthly nutrient return with litterfall of the different treatments in the studied montane forest in Ecuador after one year of nutrient addition. 91 


\section{LIST OF TABLES}

\section{CHAPTER II}

Table 1. Relative abundance of methanogenic archaea in the tank water. 34

Table $2 .{ }^{13} \mathrm{CH}_{4}$ tracer experiment with three bromeliad individuals.

Table 3. Bromeliad densities, $\mathrm{CH}_{4}$ emission from single bromeliad tanks with lower and upper 95\% confidence limits and resulting $\mathrm{CH}_{4}$ ecosystem emission from bromeliads with lower and upper prediction limits. 39

\section{CHAPTER III}

Table 1. Site and soil characteristics (mean \pm SE, $n=3$ ) of the forest sites across the elevation gradient, determined in November 2007 before the first nutrient application.

Table 2. Forest stand characteristics of the forest sites across the elevation gradient. .. 54 Table 3. Mean $( \pm \mathrm{SE}, n=3)$ net rates of soil $\mathrm{N}$ cycling $\left(\mathrm{ng} \mathrm{N} \mathrm{cm}^{-2} \mathrm{~h}^{-1}\right)$ in the forest sites across the elevation gradient, measured in the top 5-cm depth in September 2008 after two nutrient applications and in September 2009 after four nutrient applications. 61

\section{CHAPTER IV}

Table 1. Site and forest characteristics at the three forest sites and forest productivity determined from the control plots. 81 


\section{CHAPTER I}

GENERAL INTRODUCTION 


\section{SOIL TRACE GAS FLUXES IN TROPICAL MONTANE FORESTS}

Carbon dioxide $\left(\mathrm{CO}_{2}\right)$, methane $\left(\mathrm{CH}_{4}\right)$ and nitrous oxide $\left(\mathrm{N}_{2} \mathrm{O}\right)$ are important long-lived greenhouse gases and their atmospheric concentrations are steadily increasing and contribute to climate change (IPCC 2007). The sources and sinks of these trace gas fluxes have rarely been studied in tropical forests although biogeochemical cycles in tropical forest ecosystems are highly vulnerable to climate change (Malhi \& Phillips 2004). Most studies on soil trace gas fluxes are heavily biased towards lowland tropical forests (Purbopuspito et al. 2006) and the biogeochemical cycles of tropical montane forests is only starting to be explored (Girardin et al. 2010).

Tropical forests account for approximately $40 \%$ of terrestrial net primary productivity (Potter et al. 1993) and their soils store approximately 30\% of terrestrial soil carbon (C) (Jobbagy \& Jackson 2000). Soil $\mathrm{CO}_{2}$ efflux (soil respiration), which consists of root respiration (autotrophic respiration) and microbial respiration (heterotrophic respiration), is the second-largest terrestrial C flux (IPCC 2007) and tropical forest soils release more $\mathrm{C}$ into the atmosphere than any other biome (Raich et al. 2002). The rate and quantity of soil respiration is determined by the productivity of living organisms and controlled by soil temperature, moisture and substrate availability and other soil properties (Davidson et al. 2000, Luo \& Zhou 2006). Rates of soil respiration in tropical montane forests are lower compared to tropical lowland forests (Koehler et al. 2009a, McGroddy \& Silver 2000, Raich 1998, Werner et al. 2006).

Tropical forests account for approximately 70\% of terrestrial nitrogen (N) fixation (Wang \& Houlton 2009) and their soils are the major natural source of $\mathrm{N}_{2} \mathrm{O}$ (IPCC 2007). The soil source strength for $\mathrm{N}_{2} \mathrm{O}$ is determined by the $\mathrm{N}$ availability and the activity of nitrifying/denitrifying microbial communities and on soil diffusivity, which is controlled mainly by soil water, and on concurrent $\mathrm{N}_{2} \mathrm{O}$ consumption processes (Davidson et al. 2000). $\mathrm{N}_{2} \mathrm{O}$ emissions from tropical montane forest soils are much lower compared to tropical lowland forest soils. This decline in $\mathrm{N}_{2} \mathrm{O}$ emissions may be attributed to decreased $\mathrm{N}$ availability and soil $\mathrm{N}$ cycling rates due to increased nutrient limitations and lower soil temperatures at higher elevations. $\mathrm{N}_{2} \mathrm{O}$ emissions from 
tropical montane forest soils range between 0.04 and $16.37 \mathrm{~g} \mathrm{~N}_{2} \mathrm{O} \mathrm{ha} \mathrm{h}^{-1} \mathrm{~d}^{-1}$ (Breuer et al. 2000, Holtgrieve et al. 2006, Ishizuka et al. 2005, Koehler et al. 2009a, Purbopuspito et al. 2006)

Furthermore, natural tropical soils are one of the major sinks of $\mathrm{CH}_{4}$ (Dutaur \& Verchot 2007). The net soil-atmosphere $\mathrm{CH}_{4}$ flux is the result of the balance between methanogenesis (microbial $\mathrm{CH}_{4}$ production under anaerobic conditions) and methanotrophy (microbial $\mathrm{CH}_{4}$ consumption under aerobic conditions) (Conrad 1996). Methanotrophy is the dominant process in tropical montane forest soils, where $\mathrm{CH}_{4}$ oxidation generally exceeds $\mathrm{CH}_{4}$ production (Dutaur \& Verchot 2007). Therefore, tropical montane forest soils show a net uptake of $\mathrm{CH}_{4}$ (Megonigal \& Guenther 2008). Soils, where methanogenesis dominate, are mainly wetland soils (Melack \& Hess 2009) and rice paddy soils (Conrad 2009). $\mathrm{CH}_{4}$ uptake from tropical montane forest soils range between -2.5 and -10 g CH$_{4}$ ha $^{-1} \mathrm{~d}^{-1}$ (Dutaur \& Verchot 2007, Purbopuspito et al. 2006)

\section{2 “MISSING" SOURCES OF METHANE AND NITROUS OXIDE IN TROPICAL FORESTS}

The quest for the "missing" source of $\mathrm{CH}_{4}$ emissions from tropical forests started in the last decade, when increased $\mathrm{CH}_{4}$ concentrations over tropical lowland and montane forests were observed (Frankenberg et al. 2005).

The quest for the "missing" $\mathrm{CH}_{4}$ source still remains unsolved. Melack \& Hess (2009) suggested that underestimation of soil wetland emissions may account for most of the unidentified $\mathrm{CH}_{4}$ emissions over tropical regions but they fail to explain the increased $\mathrm{CH}_{4}$ concentrations over tropical montane forests, where soil wetlands almost not exist. In contrast, do Carmo et al. (2006) suggested that wetland emissions may not be the sole source of $\mathrm{CH}_{4}$. There is rather a dispersed $\mathrm{CH}_{4}$ source in tropical forests that includes $\mathrm{CH}_{4}$ emissions from termites (Fraser et al. 1986), $\mathrm{CH}_{4}$ emissions from the anaerobic decay of waterlogged wood (do Carmo et al. 2006) and $\mathrm{CH}_{4}$ emissions from poorly 
drained soil patches (Keller et al. 2005). However, none of these sources, except for termite $\mathrm{CH}_{4}$ production, has been quantified.

A promising new direction of research opened up, when Keppler et al. $(2006,2008)$ found out that terrestrial plants emit $\mathrm{CH}_{4}$ under aerobic conditions by chemical degradation of plant pectin. $\mathrm{CH}_{4}$ emissions from plants could be the "missing" $\mathrm{CH}_{4}$ source in tropical forests. However, Dueck et al. (2007) and Beerling et al. (2008) could not reproduce the original results and McLeod et al. (2008) and Nisbet et al. (2009) showed that only under high UV stress conditions instead of photosynthetically active radiation, spontaneous breakdown of plant material occurs and $\mathrm{CH}_{4}$ is released.

There are other additional processes that stoke up the debate on the role of plants as a source of methane (Conrad 2009). $\mathrm{CH}_{4}$ can be transported in gaseous form from anoxic soils through the plant aerenchyma system into the atmosphere (Joabsson et al. 1999). Furthermore, dissolved $\mathrm{CH}_{4}$ can be transported by the plant's transpiration stream from the anoxic soil into the atmosphere (Gauci et al. 2010, Terazawa et al. 2007). Finally, $\mathrm{CH}_{4}$ can be produced inside living tree stems by a methanogenic community (Zeikus \& Ward 1974). However, all of these processes have rarely been studied in tropical regions (Eliseev et al. 2008) and are mainly observed in plants growing in soil wetlands. Therefore, they are unable to explain the high $\mathrm{CH}_{4}$ concentrations over tropical montane forests.

\section{CANOPY "WETLANDS"}

Soil wetlands account for approximately $23 \%$ of total global $\mathrm{CH}_{4}$ emissions (Conrad 2009). Potential $\mathrm{CH}_{4}$ emissions from canopy wetlands have so far been neglected. The forest canopy is one of the world's least known ecosystems. It is the functional interface between $90 \%$ of terrestrial biomass and atmosphere and strongly influences the hydrology (Calder 2001) and nutrient cycling in forests (Hinko-Najera Umana \& Wanek 2010). Furthermore, the tropical forest canopy is among the most species-rich ecosystems (Ozanne et al. 2003). Tropical montane forests receive regularly substantial 
moisture input from fog (Bruijnzeel 2005) and are therefore also called "cloud forests". In this ecosystem epiphytic vascular plants and bryophytes (mosses and liverworts) reach their highest diversity and greatest abundance (Cardelus \& Mack 2010). Tank bromeliads belonging to the family of Bromeliaceae are common epiphytes throughout neotropical montane forests (Nadkarni 1984). They belong to the Phytotelmata, a class of plant-based container habitats (Kitching 2000). Other phytotelmata are hollow bamboo internodes, tree holes, non-bromeliad leaf axils. Phytotelmata in the tropical forest canopy are able to collect effectively leaf litter and rainwater and to store it for a relatively long period of time (Kitching 2000). Hence, this aquatic habitat is likely inhabited by a diverse microbial community that is different from its environment, including even methanogenic archaea who are able to produce $\mathrm{CH}_{4}$.

\section{NUTRIENT CONTROLS ON SOIL RESPIRATION AND SOIL $\mathrm{N}_{2} \mathrm{O}$ FLUXES IN TROPICAL MONTANE FORESTS}

Neotropical montane forests are known to be the top global biodiversity hot spot (Myers et al. 2000). However, they are among the least-studied tropical ecosystems with respect to ecosystem functioning (Bruijnzeel 2005). Neotropical montane and lowland forests contain about the same amount of biomass but in contrast to tropical lowland forests, most of the biomass is stored in the thick organic layers of tropical montane forests (Girardin et al. 2010). Most of the nutrients stored in this thick organic layer are not actively cycling (Grubb 1977) because low temperature at higher elevations may inhibit decomposition processes. This lack of nutrient availability led Tanner et al. (1998) to conclude that tropical montane forests are limited by nitrogen $(\mathrm{N})$ and phosphorus $(\mathrm{P})$, simultaneously. $\mathrm{N}$ and $\mathrm{P}$ are the most common limiting nutrients in terrestrial ecosystems (Vitousek et al. 2010) and natural tropical forests generate one third of terrestrial net primary production. Hence, a strong focus lies on studies about $\mathrm{N}$ and $\mathrm{P}$ limitation of vegetation growth in the tropics. Tropical lowland forests grow on heavily weathered soils. They are thought to be P limited because P is mainly derived from the 
substrate and is already depleted in heavily weathered soils. In contrast, tropical montane forests grow on younger soils. They are thought to be $\mathrm{N}$ limited because $\mathrm{N}$ is primarily derived from the atmosphere and accumulates as soils develop (Walker \& Syers 1976).

Nutrient controls on the tropical $\mathrm{C}$ cycle are largely unknown although there is increasing evidence from literature that multiple nutrients determine rates of $\mathrm{C}$ cycling (Townsend et al. 2011). Nutrient controls on belowground C cycling in the tropics have far less been studied than on aboveground C cycling (Liu \& Greaver 2010) although soil $\mathrm{CO}_{2}$ efflux is higher in the tropics than in any other biome (Raich et al. 2002). Since belowground and aboveground $\mathrm{C}$ cycles are highly interrelated, nutrient limitations of ecosystem processes (e.g vegetation growth, decomposition etc.) is the key to understand the responses of soil respiration on future environmental changes. Most research has focused on N-addition effects on soil respiration (Liu \& Greaver 2010) because of high atmospheric $\mathrm{N}$ deposition rates in temperate regions (Galloway et al. 2008). Atmospheric $\mathrm{N}$ deposition in tropical regions is also increasing but nutrient manipulation experiments in the tropics have rarely been conducted and the existing ones do not show a coherent pattern. N-rich tropical lowland forests show a stimulation of soil respiration (Cleveland \& Townsend 2006), a reduction of soil respiration (Mo et al. 2008) or no change following $\mathrm{N}$ addition (Koehler et al. 2009a). In contrast, it is generally suggested that soil $\mathrm{C}$ storage increases and soil respiration decreases in $\mathrm{N}$ rich temperate forest ecosystems due to an inhibition of microbial activity (Janssens et al. 2010, Liu \& Greaver 2010). In N limited tropical montane forest ecosystem it is suggested that $\mathrm{N}$ addition leads to a reduction of soil respiration due to stimulation of forest growth and a shift in $\mathrm{C}$ partitioning from below to aboveground along with a reduction in root respiration. However, there has been only one study that has found a reduction of soil respiration in N limited tropical montane forests (Koehler et al. 2009a).

Nutrient controls on soil $\mathrm{N}$ cycling and $\mathrm{N}_{2} \mathrm{O}$ fluxes have also been rarely studied in tropical forests. Hall \& Matson (2003) tried to predict N-addition effects on rates of soil $\mathrm{N}$ cycling and $\mathrm{N}_{2} \mathrm{O}$ losses from nutrient limitation of vegetation. In $\mathrm{N}$ rich tropical lowland forests that grow on highly weathered soils and where $\mathrm{N}$ supply exceeds biological $\mathrm{N}$ demand, soil $\mathrm{N}$ availability is high. These forests should react with immediate and large soil $\mathrm{N}_{2} \mathrm{O}$ losses following $\mathrm{N}$ additions while in $\mathrm{N}$ limited tropical 
montane forests that grow on relatively young soils and where biological $\mathrm{N}$ demand exceeds $\mathrm{N}$ supply, soil $\mathrm{N}$ availability is low. These forests should not react with immediate and large losses of $\mathrm{N}_{2} \mathrm{O}$ (Koehler et al. 2009b). However, Koehler et al. (2009b) and Corre et al. (2010) found immediate increases of soil $\mathrm{N}_{2} \mathrm{O}$ emissions following $\mathrm{N}$ addition in $\mathrm{N}$ limited tropical montane forests and suggested that $\mathrm{N}$-addition effects on rates of soil $\mathrm{N}$ cycling and $\mathrm{N}_{2} \mathrm{O}$ losses are more determined by soil type, presence of an organic layer and soil properties than by nutrient limitation of vegetation growth.

\section{PROJECT OBJECTIVES}

The quest for the "missing" $\mathrm{CH}_{4}$ source remains unsolved. Potential $\mathrm{CH}_{4}$ emissions from canopy wetlands in neotropical montane forests have not been investigated. Phytotelmata like tank bromeliads, common epiphytic vascular plants in the canopy of neotropical montane forests seem to be an ideal habitat for a methanogenic community that is able to produce $\mathrm{CH}_{4}$. Therefore, the first objective of this study was to identify and quantify $\mathrm{CH}_{4}$ emissions from tank bromeliads in neotropical montane forests.

Projected increases of atmospheric $\mathrm{N}$ deposition in tropical regions are suggested to alter rates of soil $\mathrm{N}$ cycling and soil $\mathrm{N}_{2} \mathrm{O}$ fluxes (Galloway et al. 2008) and soil respiration (Townsend et al. 2011) . However, nutrient controls on soil N cycling, soil $\mathrm{N}_{2} \mathrm{O}$ fluxes and soil respiration have rarely been studied in neotropical montane forests. Therefore, the second objective of this study was to identify nutrient controls on soil nitrogen cycling and soil $\mathbf{N}_{2} \mathrm{O}$ fluxes and the third objective of this study was to identify nutrient controls on soil respiration along an elevation gradient in neotropical montane forests by means of a nutrient manipulation experiment (i.e. $\mathrm{N}, \mathrm{P}$, $\mathrm{N}+\mathrm{P}$, and control). 


\section{STUDY AREA}

Our research was conducted within the Podocarpus National Park in the Cordillera del Consuelo, a part of the eastern chain of the Andes in southern Ecuador. Three study sites were selected along an altitudinal gradient: 990-1100 m above see level (Bombuscaro, $4.115^{\circ} \mathrm{S}, 78.968^{\circ} \mathrm{W}$; hereafter called the '1000-m site'), 1950-2100 $\mathrm{m}$ (Reserva Biologica San Francisco (RBSF), 3.982 ${ }^{\circ} \mathrm{S}, 79.083^{\circ} \mathrm{W}$; hereafter called the '2000-m site') and 2900-3050 $\mathrm{m}$ (Cajanuma, $4.110^{\circ} \mathrm{S}, 79.178^{\circ} \mathrm{W}$; hereafter called the '3000-m site'; Figure 1). Along this altitudinal gradient, annual mean temperature decreased from $\sim 19^{\circ} \mathrm{C}$ at the $1000-\mathrm{m}$ to $\sim 10^{\circ} \mathrm{C}$ at the $3000-\mathrm{m}$ site and annual precipitation ranged between $\sim 2230 \mathrm{~mm}$ at the $1000-\mathrm{m}, \sim 2000 \mathrm{~mm}$ at the $2000-\mathrm{m}$ and $\sim 4500 \mathrm{~mm}$ at the 3000-m site (Moser et al. 2007). Fabian et al. (2005) reported an ambient nitrogen deposition ranging from 1.5 to $4.4 \mathrm{~kg} \mathrm{~N} \mathrm{ha}^{-1} \mathrm{yr}^{-1}$ in the study area.

The 1000-m site consists of an old-growth premontane rain forest over deeply weathered granitic rock with an estimated canopy height between $20 \mathrm{~m}$ and $25 \mathrm{~m}$. The 2000-m site consists of an old-growth lower montane rain forest with an estimated canopy height between $12 \mathrm{~m}$ and $14 \mathrm{~m}$, and the 3000-m site consists of an old-growth upper montane rain forest with an estimated canopy height between $6 \mathrm{~m}$ and $8 \mathrm{~m}$ (Figure 2). The parent material for the $2000-\mathrm{m}$ and $3000-\mathrm{m}$ site is Paleozoic metamorphosed schist and sandstone with some quartz veins (J. Homeier, unpublished results; Litherland et al. 1994).

At the 2000-m and 3000-m sites the mineral soil was covered with a thick organic layer at the surface which consisted of decomposing leaves (L layer), a fermentation layer (Of layer), and a humus layer (Oh layer). At both sites soils were classified as Cambisol and/or Histosol (IUSS Working Group WRB 2006). At the 1000-m site only an L layer was present. The soil was classified as Cambisol (IUSS Working Group WRB 2006). 


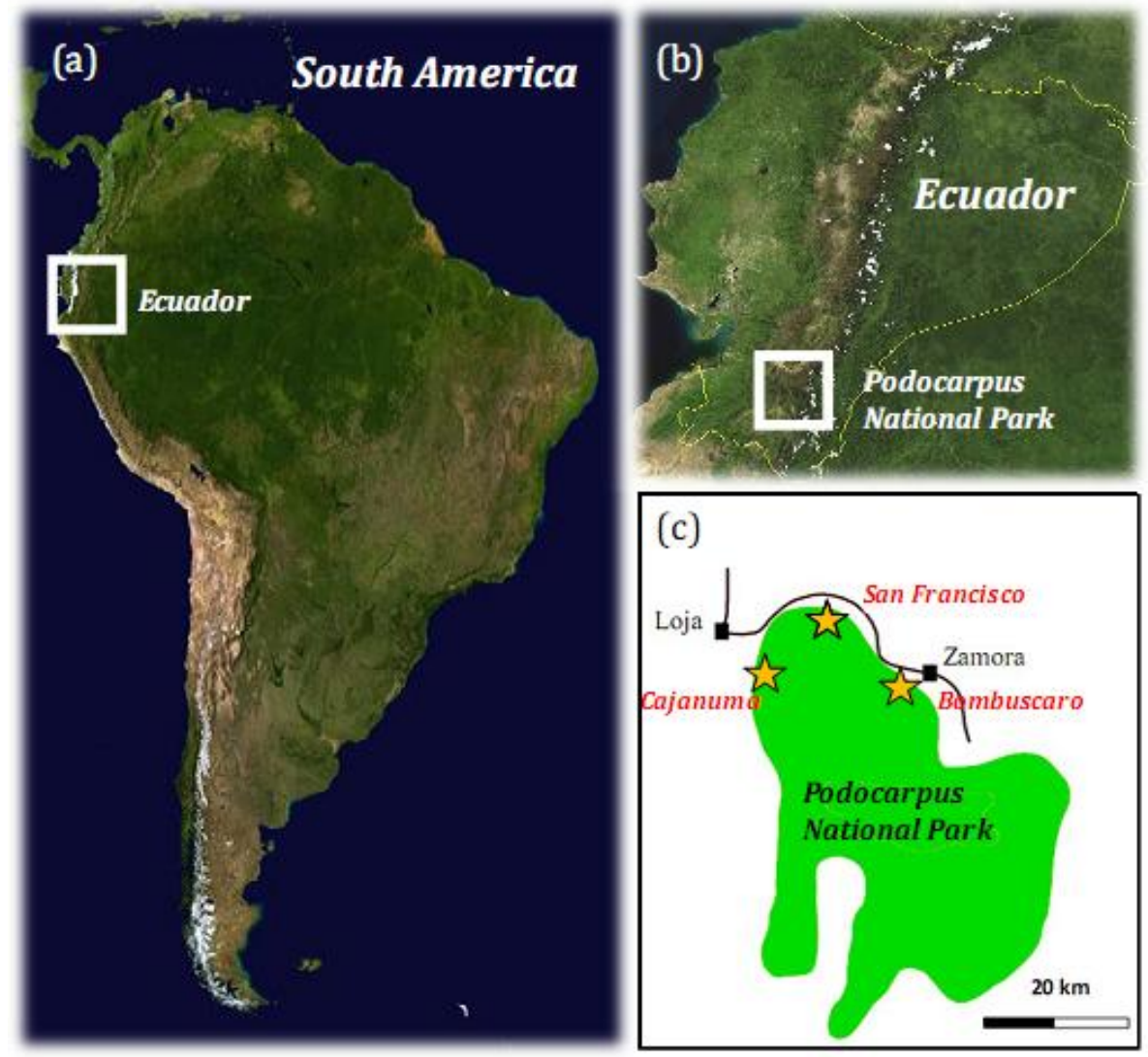

Figure 1. Location of the three study sites in the tropical montane forests of Southern Ecuador. Map sources: a, b) NASA World Wind 1.4. 0; c) adapted from G. Brehm (2002). 


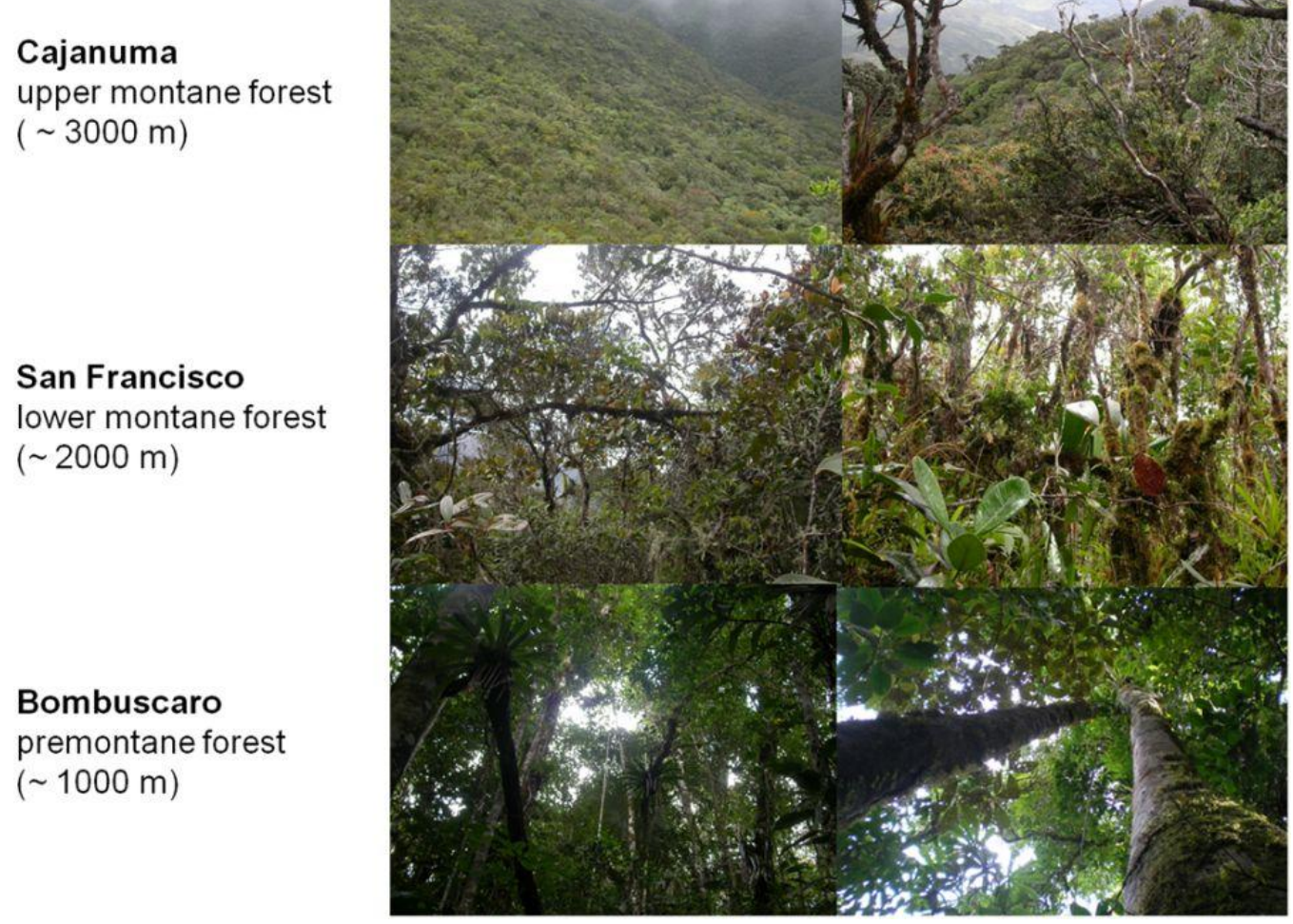

Figure 2. Forest vegetation at the three study sites in the tropical montane forests of Southern Ecuador. Photographs from J. Homeier.

\section{EXPERIMENTAL DESIGN OF THE NUTRIENT MANIPULATION EXPERIMENT (NUMEX)}

For our first objective we established a NUtrient Manipulation Experiment (NUMEX) (Figure 3). At each site $(1000 \mathrm{~m}, 2000 \mathrm{~m}$ and $3000 \mathrm{~m})$ a factorial NP fertilization (i.e. N, P, $\mathrm{NP}$, control) in a stratified random design with three replicate plots per treatment and 20-m x 20-m area each plot was conducted. The three replicate strata covered short topographic gradients and were treated as statistical blocks, as nutrient availability and 
other soil factors can vary over relatively small topographic gradients in these forests. Fertilizer treatments, applied twice a year began in February 2008. Fertilizers were applied to reach the following total doses for each year's two applications: $50 \mathrm{~kg} \mathrm{~N} \mathrm{ha-1}$ year-1 as urea and $10 \mathrm{~kg} \mathrm{P} \mathrm{ha}^{-1}$ year-1 as $\mathrm{NaH}_{2} \mathrm{PO}_{4} \cdot 2 \mathrm{H}_{2} \mathrm{O}$ with analytical grade quality.

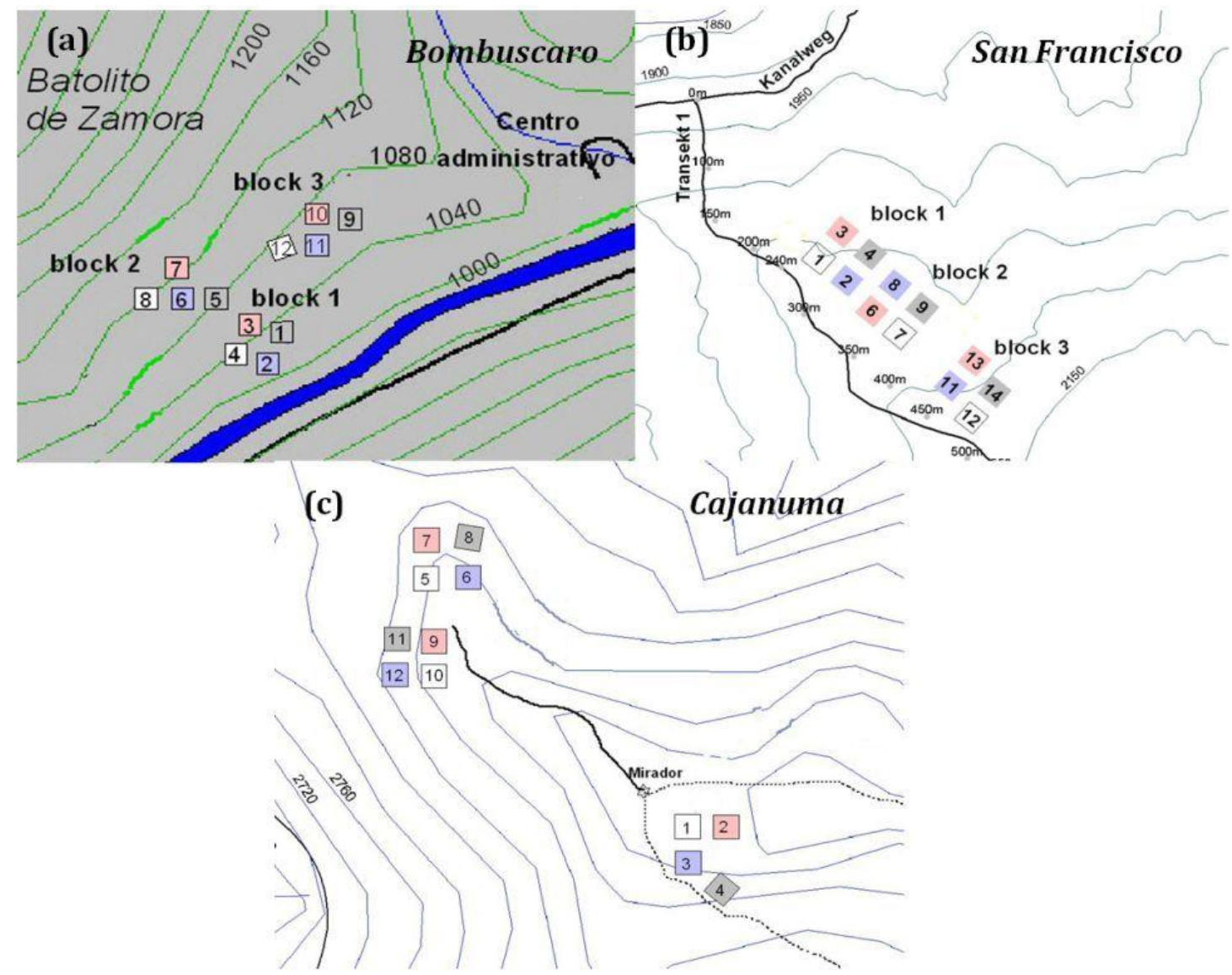

Figure 3. NUtrient Manipulation EXperiment (NUMEX) plot layout at the three forest sites in the tropical montane forests of Southern Ecuador (adapted from J. Homeier). 


\section{SET UP FOR INVESTIGATION OF METHANE EMISSIONS FROM TANK BROMELIADS}

We sampled 167 bromeliads in an area of approximately six hectares. Twelve accessible canopy trees were randomly selected and climbed with arborist techniques. A maximum of seven bromeliads were sampled from a single central tree and seven other bromeliads from neighbouring trees or from the ground next to the central tree. Plants were chosen randomly from different height strata, functional types, and size classes and collected under variable weather conditions (e.g. immediately after torrential rains or week-long dry spells). Individual bromeliads were carefully detached from the substrate and immediately lowered to the ground in a basket in their natural growth position, without losing tank water (Figure 4).
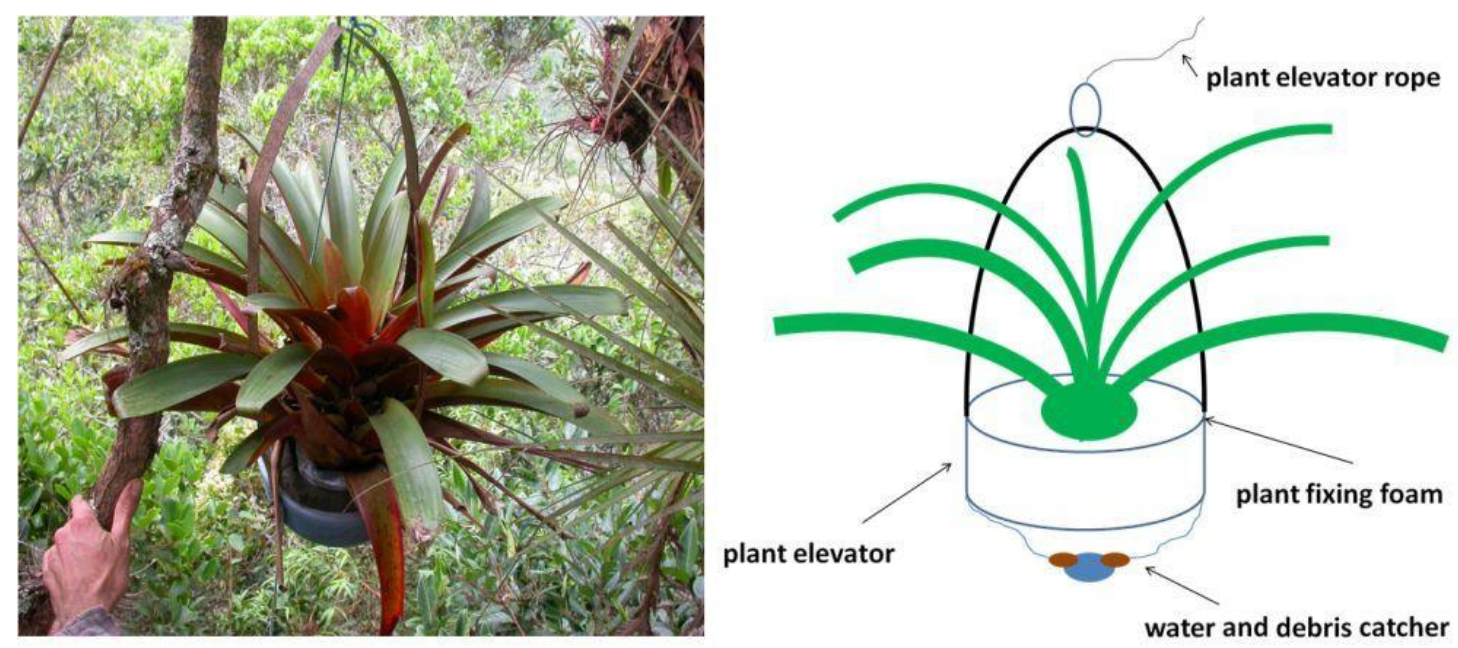

Figure 4. Tank bromeliad elevator (left photograph from F. Werner). 


\section{REFERENCES}

Beerling, D. J., T. Gardiner, G. Leggett, A. McLeod, and W. P. Quick. 2008. Missing methane emissions from leaves of terrestrial plants. Global Change Biology 14:1821-1826.

Breuer, L., H. Papen, and K. Butterbach-Bahl. 2000. $\mathrm{N}_{2} \mathrm{O}$ emission from tropical forest soils of Australia. Journal of Geophysical Research-Atmospheres 105:2635326367.

Bruijnzeel, L. A. 2005. Tropical montane cloud forests: a unique hydrological case. Pages 462-483 in M. Bonell, and L. A. Bruijnzeel editors. Forests, water and people in the humid Tropics. Cambridge University Press. Cambridge.

Brehm, G. 2002. Diversity of geometrid moths in a montane rainforest in Ecuador. Dissertation. University of Bayreuth, Germany.

Calder, I. R. 2001. Canopy processes: implications for transpiration, interception and splash induced erosion, ultimately for forest management and water resources. Plant Ecology 153:203-214.

Cardelus, C. L., and M. C. Mack. 2010. The nutrient status of epiphytes and their host trees along an elevational gradient in Costa Rica. Plant Ecology 207:25-37.

Cleveland, C. C., and A. R. Townsend. 2006. Nutrient additions to a tropical rain forest drive substantial soil carbon dioxide losses to the atmosphere. Proceedings of the National Academy of Sciences of the United States of America 103:10316-10321.

Conrad, R. 1996. Soil microorganisms as controllers of atmospheric trace gases $\left(\mathrm{H}_{2}, \mathrm{CO}\right.$, $\mathrm{CH}_{4}, \mathrm{OCS}, \mathrm{N}_{2} \mathrm{O}$, and NO). Microbiological Reviews 60:609-640.

Conrad, R. 2009. The global methane cycle: Recent advances in understanding the microbial processes involved [Minireview]. Environmental Microbiology Reports 1:285-292. 
Corre, M. D., E. Veldkamp, J. Arnold, and S. J. Wright. 2010. Impact of elevated N input on soil N cycling and losses in old-growth lowland and montane forests in Panama. Ecology 91:1715-1729.

Davidson, E. A., M. Keller, H. E. Erickson, L. V. Verchot, and E. Veldkamp. 2000. Testing a conceptual model of soil emissions of nitrous and nitric oxides. Bioscience 50:667-680.

do Carmo, J. B., M. Keller, J. D. Dias, P. B. de Camargo, and P. Crill. 2006. A source of methane from upland forests in the Brazilian Amazon. Geophysical Research Letters 33.

Dueck, T. A., R. de Visser, H. Poorter, S. Persijn, A. Gorissen, W. de Visser, A. Schapendonk, J. Verhagen, J. Snel, F. J. M. Harren, A. K. Y. Ngai, F. Verstappen, H. Bouwmeester, L. Voesenek, and A. van der Werf. 2007. No evidence for substantial aerobic methane emission by terrestrial plants: a C-13-labelling approach. New Phytologist 175:29-35.

Dutaur, L., and L. V. Verchot. 2007. A global inventory of the soil $\mathrm{CH}_{4}$ sink. Global Biogeochemical Cycles 21, GB4013, doi:10.1029/2006GB002734.

Eliseev, A. V., I. I. Mokhov, M. M. Arzhanov, P. F. Demchenko, and S. N. Denisov. 2008. Interaction of the methane cycle and processes in wetland ecosystems in a climate model of intermediate complexity. Izvestiya Atmospheric and Oceanic Physics 44:139-152.

Fabian, P., M. Kohlpaintner, and R. Rollenbeck. 2005. Biomass burning in the Amazonfertilizer for the mountaineous rain forest in Ecuador. Environmental Science and Pollution Research 12:290-296.

Frankenberg, C., J. F. Meirink, M. van Weele, U. Platt, and T. Wagner. 2005. Assessing methane emissions from global space-borne observations. 308:1010-1014.

Fraser, P. J., R. A. Rasmussen, J. W. Creffield, J. R. French, and M. A. K. Khalil. 1986. Termites and global methane - another assessment. Journal of Atmospheric Chemistry 4:295-310. 
Galloway, J. N., A. R. Townsend, J. W. Erisman, M. Bekunda, Z. C. Cai, J. R. Freney, L. A. Martinelli, S. P. Seitzinger, and M. A. Sutton. 2008. Transformation of the nitrogen cycle: Recent trends, questions, and potential solutions. Science 320:889-892.

Gauci, V., D. J. G. Cowing, E. R. C. Hornibrook, J. M. Davis, and N. B. Dise. 2010. Woody stem methane emission in mature wetland alder trees. Atmospheric Environment 44:2157-2160.

Girardin, C. A. J., Y. Malhi, L. E. O. C. Aragao, M. Mamani, W. H. Huasco, L. Durand, K. J. Feeley, J. Rapp, J. E. Silva-Espejo, M. Silman, N. Salinas, and R. J. Whittaker. 2010. Net primary productivity allocation and cycling of carbon along a tropical forest elevational transect in the Peruvian Andes. Global Change Biology 16:3176-3192.

Grubb, P. J. 1977. Control of forest growth and distribution on wet tropical mountains with special reference to mineral-nutrition. Annual Review of Ecology and Systematics 8:83-107.

Hall, S. J., and P. A. Matson. 2003. Nutrient status of tropical rain forests influences soil N dynamics after N additions. Ecological Monographs 73:107-129.

Hinko-Najera Umana, N., and W. Wanek. 2010. Large canopy exchange fluxes of inorganic and organic nitrogen and preferential retention of nitrogen by epiphytes in a tropical lowland rainforest. Ecosystems 13:367-381.

Holtgrieve, G. W., P. K. Jewett, and P. A. Matson. 2006. Variations in soil N cycling and trace gas emissions in wet tropical forests. Oecologia 146:584-594.

IPCC. Climate Change 2007: The Physical Science Basis. Contribution of working group I to the fourth assessment report of the Intergovernmental Panel on Climate Change. Solomon, S., Manning, M., Chen, Z., Marquis, M., Averyt, K. B., Tignor, M., and Miller, H. L. 2007. Cambridge University Press, Cambridge, United Kingdom and New York, USA.

Ishizuka, S., A. Iswandi, Y. Nakajima, S. Yonemura, S. Sudo, H. Tsuruta, and D. Murdiyarso. 2005. The variation of greenhouse gas emissions from soils of various land- 
use/cover types in Jambi province, Indonesia. Nutrient Cycling in Agroecosystems 71:17-32.

IUSS Working Group WRB. 2006. World reference base for soil resources., 2nd edition. FAO, Rome.

Janssens, I. A., W. Dieleman, S. Luyssaert, J. A. Subke, M. Reichstein, R. Ceulemans, P. Ciais, A. J. Dolman, J. Grace, G. Matteucci, D. Papale, S. L. Piao, E. D. Schulze, J. Tang, and B. E. Law. 2010. Reduction of forest soil respiration in response to nitrogen deposition. Nature Geoscience 3:315-322.

Joabsson, A., T. R. Christensen, and B. Wallen. 1999. Vascular plant controls on methane emissions from northern peatforming wetlands. Trends in Ecology \& Evolution 14:385-388.

Jobbagy, E. G., and R. B. Jackson. 2000. The vertical distribution of soil organic carbon and its relation to climate and vegetation. Ecological Applications 10:423-436.

Keller, M., R. Varner, J. D. Dias, H. Silva, P. Crill, and R. C. de Oliveira. 2005. Soilatmosphere exchange of nitrous oxide, nitric oxide, methane, and carbon dioxide in logged and undisturbed forest in the Tapajos National Forest, Brazil. Earth Interactions 9.

Keppler, F., J. T. G. Hamilton, M. Brass, and T. Rockmann. 2006. Methane emissions from terrestrial plants under aerobic conditions. Nature 439:187-191.

Keppler, F., J. T. G. Hamilton, W. C. McRoberts, I. Vigano, M. Brass, and T. Rockmann. 2008. Methoxyl groups of plant pectin as a precursor of atmospheric methane: evidence from deuterium labelling studies. New Phytol. 178:808-814.

Kitching R. L. 2000. Food Webs and Container Habitats. Cambridge University Press, Cambridge, UK.

Koehler, B., M. D. Corre, E. Veldkamp, and J. P. Sueta. 2009a. Chronic nitrogen addition causes a reduction in soil carbon dioxide efflux during the high stem-growth 
period in a tropical montane forest but no response from a tropical lowland forest on a decadal time scale. Biogeosciences 6:2973-2983.

Koehler, B., M. D. Corre, E. Veldkamp, H. Wullaert, and S. J. Wright. 2009b. Immediate and long-term nitrogen oxide emissions from tropical forest soils exposed to elevated nitrogen input. Global Change Biology 15:2049-2066.

Litherland, M., J. A. Aspden, and R. A. Jemielita. 1994. The metamorphic belts of Ecuador. Overseas Memoir 11.

Liu, L. L., and T. L. Greaver. 2010. A global perspective on belowground carbon dynamics under nitrogen enrichment. Ecology Letters 13:819-828.

Luo Y., and X. Zhou. 2006. Soil Respiration and the Environment, Eds. Academic Press, Burlington, San Diegom London.

Malhi, Y., and O. L. Phillips. 2004. Tropical forests and global atmospheric change: a synthesis. Philosophical Transactions of the Royal Society of London Series BBiological Sciences 359:549-555.

McGroddy, M., and W. L. Silver. 2000. Variations in belowground carbon storage and soil $\mathrm{CO}_{2}$ flux rates along a wet tropical climate gradient. Biotropica 32:614-624.

McLeod, A. R., S. C. Fry, G. J. Loake, D. J. Messenger, D. S. Reay, K. A. Smith, and B. W. Yun. 2008. Ultraviolet radiation drives methane emissions from terrestrial plant pectins. New Phytologist 180:124-132.

Megonigal, J. P., and A. B. Guenther. 2008. Methane emissions from upland forest soils and vegetation. Tree Physiology 28:491-498.

Melack, J. M., and L. L. Hess. 2009. Remote sensing of the distribution and extent of wetlands in the Amazon basin. in W. J. Junk, and M. Piedade editors. Amazonian floodplain forests: ecophysiology, ecology, biodiversity and sustainable management. Springer, New York. 
Mo, J., W. Zhang, W. Zhu, P. Gundersen, Y. Fang, D. Li, and H. Wang. 2008. Nitrogen addition reduces soil respiration in a mature tropical forest in southern China. Global Change Biology 14:403-412.

Moser, G., D. Hertel, and C. Leuschner. 2007. Altitudinal change in LAI and stand leaf biomass in tropical montane forests: a transect shady in Ecuador and a pantropical meta-analysis. Ecosystems 10:924-935.

Myers, N., R. A. Mittermaier, C. G. Mittermaier, G. A. B. Fonseca, and J. Kent. 2000. Biodiversity hotspots for conservation priorities. Nature 403:853-858.

Nadkarni, N. M. 1984. Epiphyte Biomass and Nutrient Capital of A Neotropical Elfin Forest. Biotropica 16:249-256.

Nisbet, R. E. R., R. Fisher, R. H. Nimmo, D. S. Bendall, P. M. Crill, A. V. Gallego-Sala, E. R. C. Hornibrook, E. Lopez-Juez, D. Lowry, P. B. R. Nisbet, E. F. Shuckburgh, S. Sriskantharajah, C. J. Howe, and E. G. Nisbet. 2009. Emission of methane from plants. Philosophical Transactions of the Royal Society of London Series BBiological Sciences 276:1347-1354.

Ozanne, C. M. P., D. Anhuf, S. L. Boulter, M. Keller, R. L. Kitching, C. Korner, F. C. Meinzer, A. W. Mitchell, T. Nakashizuka, P. L. S. Dias, N. E. Stork, S. J. Wright, and M. Yoshimura. 2003. Biodiversity meets the atmosphere: A global view of forest canopies. Science 301:183-186.

Potter, C. S., J. T. Randerson, C. B. Field, P. A. Matson, P. M. Vitousek, H. A. Mooney, and S. A. Klooster. 1993. Terrestrial ecosystem production - a process model-based on global satellite and surface data. Global Biogeochemical Cycles 7:811-841.

Purbopuspito, J., E. Veldkamp, R. Brumme, and D. Murdiyarso. 2006. Trace gas fluxes and nitrogen cycling along an elevation sequence of tropical montane forests in Central Sulawesi, Indonesia. Global Biogeochemical Cycles 20. GB3010, doi:10.1029/2005GB002516.

Raich, J. W. 1998. Aboveground productivity and soil respiration in three Hawaiian rain forests. Forest Ecology and Management 107:309-318. 
Raich, J. W., C. S. Potter, and D. Bhagawati. 2002. Interannual variability in global soil respiration, 1980-94. Global Change Biology 8:800-812.

Raich, J. W., and W. H. Schlesinger. 1992. The global carbon-dioxide flux in soil respiration and its relationship to vegetation and climate. Tellus Series BChemical and Physical Meteorology 44:81-99.

Tanner, E. V. J., P. M. Vitousek, and E. Cuevas. 1998. Experimental investigation of nutrient limitation of forest growth on wet tropical mountains. Ecology 79:10-22.

Terazawa, K., S. Ishizuka, T. Sakatac, K. Yamada, and M. Takahashi. 2007. Methane emissions from stems of Fraxinus mandshurica var. japonica trees in a floodplain forest. Soil Biology and Biochemistry 39:2689-2692.

Townsend, A. R., C. C. Cleveland, B. Z. Houlton, C. B. Alden, and J. W. C. White. 2011. Multielement regulation of the tropical forest carbon cycle. Frontiers in Ecology and the Environment 9:9-17.

Vitousek, P. M., S. Porder, B. Z. Houlton, and O. A. Chadwick. 2010. Terrestrial phosphorus limitation: mechanisms, implications, and nitrogen-phosphorus interactions. Ecological Applications 20:5-15.

Walker, T. W., and J. K. Syers. 1976. Fate of phosphorus during pedogenesis. Geoderma 15:1-19.

Wang, Y. P., and B. Z. Houlton. 2009. Nitrogen constraints on terrestrial carbon uptake: Implications for the global carbon-climate feedback. Geophysical Research Letters 36.

Werner, C., X. H. Zheng, J. W. Tang, B. H. Xie, C. Y. Liu, R. Kiese, and K. Butterbach-Bahl. 2006. $\mathrm{N}_{2} \mathrm{O}, \mathrm{CH}_{4}$ and $\mathrm{CO}_{2}$ emissions from seasonal tropical rainforests and a rubber plantation in Southwest China. Plant and Soil 289:335-353.

Zeikus, J. G., and J. C. Ward. 1974. Methane formation in living trees: a microbial origin. Science 184:1181-1183. 


\section{CHAPTER II}

\section{METHANE EMISSIONS FROM TANK BROMELIADS IN NEOTROPICAL FORESTS}

A REVISED VERSION IS PUBLISHED IN: NATURE GEOSCIENCE, 2010, 3, 766-769

Guntars O. Martinson ${ }^{1}$, Florian A. Werner², Christoph Scherber ${ }^{3}$, Ralf Conrad ${ }^{4}$, Marife D.

Corre $^{1}$, Heiner Flessa ${ }^{5}$, Katrin Wolf ${ }^{1}$, Melanie Klose $^{4}$ and S. Robbert Gradstein ${ }^{6}$, Edzo Veldkamp ${ }^{1}$

${ }^{1}$ Buesgen Institute - Soil Science of Tropical and Subtropical Ecosystems, Georg-AugustUniversity of Goettingen, Goettingen, Germany

${ }^{2}$ Albrecht-von-Haller Institute of Plant Sciences, Georg-August-University of Goettingen, Goettingen, Germany

${ }^{3}$ Agroecology, Georg-August-University of Goettingen, Goettingen, Germany

${ }^{4}$ Max-Planck-Institute for Terrestrial Microbiology, Marburg, Germany

5Johann Heinrich von Thünen Institut - Institute of Agricultural Climate Research, Braunschweig, Germany 
${ }^{6}$ Muséum National d'Histoire Naturelle, Dept. Systématique et Evolution, 57 rue Cuvier, Paris, France

\section{ABSTRACT}

Methane is a potent greenhouse gas that accounts for $20-25 \%$ of radiative forcing (Shindell et al. 2009). Recent space-borne observations suggest high atmospheric methane concentrations above neotropical forest from currently unidentified sources (do Carmo et al. 2006, Frankenberg et al. 2008). This, coupled with the finding that intact plants can emit methane under aerobic conditions (Keppler et al. 2006, Keppler et al. 2008), has stimulated a heated debate on the role of vegetation as a source of methane. Here we used plant-incubation chambers, ${ }^{13} \mathrm{CH}_{4}$ tracing and molecular techniques to show that tank bromeliads, a distinctive group of herbaceous water-impounding plants and common throughout neotropical forests, can have high rates of methane emissions. The gas is produced in their water-filled leaf axils (the pouch-like basal section) by a diverse community of methanogenic archaea. The dissolved methane in bromeliad tanks appears to be absorbed by foliar hairs (trichomes), diffused into aerenchyma and emitted through stomata into the atmosphere. We estimate the methane source from a montane tropical forest ( $2100 \mathrm{~m}$ above the sea level) at $3.6 \mathrm{~g} \mathrm{ha}^{-1} \mathrm{~d}^{-1}$, which is enough to compensate for atmospheric methane consumption in the soil at a rate of $3.1 \mathrm{~g} \mathrm{ha}^{-1} \mathrm{~d}^{-1}$. The neotropical forest source may be in the range of $1.2 \mathrm{Tg} \mathrm{yr}^{-}$ 1. Tank bromeliads and other types of 'cryptic wetlands' may therefore help to explain the unidentified methane source strength of neotropical forests. 


\section{INTRODUCTION}

The concentration of methane $\left(\mathrm{CH}_{4}\right)$ in the atmosphere has more than doubled over the last two centuries. Its current concentration of about $1800 \mathrm{ppb}$ accounts for $20-25 \%$ of the total greenhouse gas radiative forcing (Shindell et al. 2009). Every year, approximately $600 \mathrm{Tg} \mathrm{CH}_{4}$ are released into the atmosphere (Prather 2001), with an estimated anthropogenic component of more than 50 percent (Conrad 2009). Wetlands are the main natural source of $\mathrm{CH}_{4}$, with an emission of $22 \mathrm{Tg} \mathrm{CH}_{4} \mathrm{yr}^{-1}$ from the Amazon basin alone (Melack \& Hess 2009). However, known wetland sources do not suffice to explain the observed amounts of $\mathrm{CH}_{4}$ over neotropical forests (Melack \& Hess 2009). The majority of neotropical forest grows on non-flooded upland soils that are assumed to be too dry to emit $\mathrm{CH}_{4}$, acting instead as an important sink for atmospheric $\mathrm{CH}_{4}$ (Megonigal \& Guenther 2008). Vertical $\mathrm{CH}_{4}$ concentration profiles within Amazonian upland forests indicate emission rates of 20-210 $\mathrm{g} \mathrm{CH}_{4} \mathrm{ha}^{-1} \mathrm{~d}^{-1}$, and research has focused on vegetation as the source of $\mathrm{CH}_{4}$ (do Carmo et al. 2006, Keppler et al. 2008). Here we show that, related to their unique anatomy, tank bromeliads create canopy wetlands that form a hitherto unrecognized source of $\mathrm{CH}_{4}$. We further present evidence that the leaves of bromeliads serve as an effective conduit for $\mathrm{CH}_{4}$ produced in their tanks. 


\section{Materials AND METHODS}

\subsection{Sampling design}

We sampled 167 bromeliads in an area of approximately six hectares. Twelve accessible canopy trees were randomly selected and climbed with arborist techniques. A maximum of seven bromeliads were sampled from a single central tree and seven other bromeliads from neighbouring trees or from the ground next to the central tree. Plants were chosen randomly from different height strata, functional types, and size classes and collected under variable weather conditions (e.g. immediately after torrential rains or week-long dry spells). Individual bromeliads were carefully detached from the substrate and immediately lowered to the ground in a basket in their natural growth position, without losing tank water.

\subsection{Methane flux measurement of bromeliads}

Methane flux was measured in the field using buckets of acrylonitrile-butadiene-styrene (ABS) as incubation chambers capped with removable lids of ABS containing two 1/16"

ports for sampling and venting. $\mathrm{CH}_{4}$ emissions did not differ, whether a dark or a transparent bucket was used. Buckets of two different sizes were used ( $20 \mathrm{~L}$ and $25 \mathrm{~L}$ ). Gas samples were collected at 2, 9, 16, 23 minutes in the 20-L bucket and at 2, 10, 18, 26 minutes in the 25-L bucket after chamber closure. Gas sampling was conducted by connecting a 3.2-mm diameter polyethylene tube with a polycarbonate Luer lock $\mathrm{t}$-valve to the bucket's sampling port on one end and, on the other end, to a polycarbonate syringe $(60 \mathrm{~mL})$ with a t-valve, a pressure gauge (GMH 3310, Greisinger electronic $\mathrm{GmbH}$, Regenstauf, Germany), and an evacuated glass bottle (65 mL) with a tefloncoated stopcock. Prior to drawing gas samples, the sampling tube was evacuated using the syringe and the vacuum integrity was checked with the pressure gauge. The stopcock on the evacuated glass bottle was then open and again the vacuum was checked. Finally, the stopcock on the bucket's sampling port was opened, drawing gas sample into the glass bottle, and the stopcocks on the sampling port and on the bottle 
were closed once the glass bottle was full (indicated by the pressure gauge). Gas samples were analysed on the day following collection using a gas chromatograph (GC - 14B, Shimadzu, Duisburg, Germany) equipped with a flame ionisation detector and an autosampler (Loftfield et al. 1997). Gas fluxes were calculated from the linear increase in gas concentration multiplied by the density of air and the volume of the chamber headspace. Air density was adjusted for air temperature and air pressure measured at the time of sampling.

Immediately after $\mathrm{CH}_{4}$ flux measurement, bromeliad tank water was carefully decanted through a 4-mm mesh sieve into a container for measuring water volume. The tank water of 53 bromeliads was sampled for analysis of methanogenic archaea, following all necessary aseptic measures. A $100-\mathrm{mL}$ water sample was taken from the tank water and frozen in a sterilised polycarbonate-bottle within a few hours after sampling. Water samples were kept continuously frozen until analysis at Max-PlanckInstitute for Terrestrial Microbiology, Marburg, Germany.

\subsection{Methane flux measurements of soil}

Soil $\mathrm{CH}_{4}$ flux was measured once a month from October 2008 to January 2009 at the same site and elevation where the fluxes from bromeliads were measured. Three plots ( $\mathrm{n}=3$ ) of $20 \times 20 \mathrm{~m}$ were established randomly, and each plot had 4 permanently installed chamber bases $\left(0.04 \mathrm{~m}^{2}\right.$ area and made of polyvinyl chloride tube). Soil $\mathrm{CH}_{4}$ fluxes were measured using vented static chambers. Four gas samples were removed at 2, 14, 26 and 38 minutes after chamber closure; similar gas sampling method and analysis were followed as described for the bromeliads.

\subsection{Methane flux measurement of bromeliad leaves}

Methane emission from bromeliad leaves was measured by inserting the distal section (approx. two-third) of an intact leaf into a 2.53-L transparent plexiglas chamber that was closed tightly around the leaf. A single leaf from six individuals ( $\mathrm{n}=6$ ) of Guzmania 
killipiana was measured in situ and gas samples were taken at 2, 17 and 32 minutes after chamber closure. Gas sampling and analysis followed the methods described for bromeliads.

\subsection{Methane concentration measurement of bromeliad tank water}

Bromeliad tank water samples of $2 \mathrm{~mL}$ were taken from six individuals $(\mathrm{n}=6)$ of Guzmania killipiana using a sterilised syringe and immediately injected into a $12-\mathrm{mL}$ septum-capped sterilised vacutainer (Labco Limited, Buckinghamshire, UK), which contained ambient air and equipped with a fine needle for pressure equilibration (Flessa et al. 2008). Prior to field sampling, vacutainers were filled with $0.5 \mathrm{~mL} \mathrm{HgCl}_{2}(0.1 \%)$ to kill any microbial activity in the tank water samples. The concentration of $\mathrm{CH}_{4}$ in the headspace of the vacutainer was analysed after $24 \mathrm{~h}$ equilibration at $25^{\circ} \mathrm{C}$. The $\mathrm{CH}_{4}$ concentration in water samples was calculated as follows (Tiedje 1982):

$$
\mathrm{M}=\mathrm{C}_{\mathrm{g}}\left(\frac{V g+V 1 \alpha}{V 1}\right)
$$

where $\mathrm{M}$ is the amount of $\mathrm{CH}_{4}$ in the water sample ( $\mu \mathrm{CH}_{4} \mathrm{~L}^{-1}$ ), $\mathrm{Cg}_{\mathrm{g}}$ is the gas concentration of vacutainer headspace $\left(\mu \mathrm{g} \mathrm{CH}_{4} \mathrm{~L}^{-1}\right), \mathrm{V}_{\mathrm{g}}$ is the gas volume (L), $\mathrm{V}_{1}$ is the solution volume (L), and $\alpha=0.03606$ is the Bunsen solubility coefficient at $25^{\circ} \mathrm{C}$. The diffusive flux of $\mathrm{CH}_{4}$ from the bromeliad tank water into the atmosphere was calculated using Fick's first law:

$$
\mathrm{J}_{\mathrm{D}}=-\mathrm{D}_{\mathrm{W}}\left(\mathrm{dCH}_{4} / \mathrm{dz}\right)
$$

where $\mathrm{J}_{\mathrm{D}}$ is the diffusive flux $\left(\mathrm{mg} \mathrm{CH} \mathrm{CH}^{-2} \mathrm{~min}^{-1}\right), \mathrm{D}_{\mathrm{W}}$ is the molecular diffusion coefficient in water at $25^{\circ} \mathrm{C}\left(\mathrm{D}_{\mathrm{W}}=1.18 \times 10^{-7} \mathrm{~m}^{2} \mathrm{~min}^{-1}\right)$ and $\mathrm{dCH}_{4} / \mathrm{dz}$ is the $\mathrm{CH}_{4}$ gradient calculated from the $\mathrm{CH}_{4}$ concentration in ambient air (ca. $1.777 \mu \mathrm{CH}_{4} \mathrm{~L}^{-1}$ ) and the $\mathrm{CH}_{4}$ concentration in bromeliad tank water. 


\subsection{Molecular analysis of methanogenic communities}

Detritus samples from 53 bromeliad tanks were transported in frozen state to the MaxPlanck-Institute for Terrestrial Microbiology in Marburg, Germany. Samples were used for extraction of DNA, PCR-amplification of archaeal 16S rRNA genes and analysis of TRFLP using a published protocol (Conrad et al. 2008). Briefly, the T-RFs larger than 1\% of total peak area were identified in all 53 samples of bromeliad tanks and assigned to known archaeal phyla using 5 clone libraries of archaeal 16S rRNA genes generated from the DNA of 5 samples from which a total of 150 clones were sequenced. The sequences were deposited at GenBank under the accession numbers GU223408 GU223557. The sequences were phylogenetically characterised by tree construction as described elsewhere (Wu et al. 2006) (Figure 4).

\section{$3.7{ }^{13} \mathrm{CH}_{4}$ tracer experiment}

We measured ${ }^{13} \mathrm{CH}_{4}$ abundance and $\mathrm{CH}_{4}$ emission from leaves of three bromeliad individuals (Guzmania melinonis, Tillandsia guatemalensis and Tillandsia viridiflora) at the Max-Planck-Institute for Terrestrial Microbiology, Marburg, Germany. The plants were taken from the botanical garden in Göttingen, Germany. All three species belong to the ecophysiological type 4 of Bromeliaceae that also includes all tank bromeliads measured at our field site. Prior to $\mathrm{CH}_{4}$ emission measurement, we removed the bromeliad tank water and inserted a leaf (which area was measured using WinFOLIA 2004a) into a 2.53-L transparent Plexiglas chamber. We then filled the bromeliad tank with $180 \mathrm{~mL}$ of water, containing a dissolved $\mathrm{CH}_{4}$ concentration of ca. $233.6 \mu \mathrm{g} \mathrm{CH}_{4} \mathrm{~L}^{-1}$ and enriched with 99 atom\% ${ }^{13} \mathrm{CH}_{4}$; this $\mathrm{CH}_{4}$ concentration is 7800 times the equilibrium concentration with the atmosphere $\left(0.03 \mu \mathrm{g} \mathrm{CH} \mathrm{L}^{-1}\right.$ at $\left.25^{\circ} \mathrm{C}\right)$. Gas sampling and analysis followed the methods described previously. $\mathrm{CH}_{4}$ concentrations increased linearly during 215 minutes of chamber closure. Additionally, we took 125-mL air samples from the chamber immediately after chamber closure and at 215 minutes after chamber closure. Another125-mL air sample was taken from the outside of but close to 
the chamber at 215 minutes. These three samples per measured leaf were analyzed for ${ }^{13} \mathrm{C}$ abundance of $\mathrm{CH}_{4}$ using gas chromatography combustion isotope ratio mass spectrometry (Brand 1996) (GC-C-IRMS; Thermoquest, Bremen, Germany). The flux of

${ }^{13} \mathrm{CH}_{4}$ was calculated by the two following equations using the data from Table 3 :

(6)

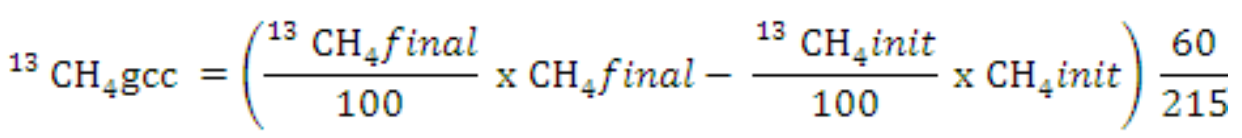

where ${ }^{13} \mathrm{CH}_{4}$ gcc is the ${ }^{13} \mathrm{CH}_{4}$ gas concentration change within the leaf chamber $\left(\mu \mathrm{L}^{13} \mathrm{CH}_{4} \mathrm{~L}^{-1} \mathrm{~h}^{-1}\right), \mathrm{CH}_{4}$ final is the $\mathrm{CH}_{4}$ concentration $\left(\mu \mathrm{L} \mathrm{CH}_{4} \mathrm{~L}^{-1}\right.$ ) in the leaf chamber at 215 minutes, ${ }^{13} \mathrm{CH}_{4}$ final is the ${ }^{13} \mathrm{C}$ abundance (atom $\%{ }^{13} \mathrm{C}$ ) of $\mathrm{CH}_{4}$ in the leaf chamber at 215 minutes, $\mathrm{CH}_{4}$ init is the initial $\mathrm{CH}_{4}$ concentration $\left(\mu \mathrm{L} \mathrm{CH}_{4} \mathrm{~L}^{-1}\right)$ in the leaf chamber, and ${ }^{13} \mathrm{CH}_{4}$ init is the initial ${ }^{13} \mathrm{C}$ abundance (atom $\%{ }^{13} \mathrm{C}$ ) of $\mathrm{CH}_{4}$ in the leaf chamber.

$$
\Phi=\frac{\mathrm{V}}{\mathrm{A}}\left(\frac{\mathrm{P}}{\mathrm{RxT}}\right) \mathrm{Mf} \mathrm{x}^{13} \mathrm{CH}_{4} \mathrm{gcc}
$$

where $\Phi$ is the ${ }^{13} \mathrm{CH}_{4}$ flux (ng ${ }^{13} \mathrm{CH}_{4} \mathrm{~cm}^{-2}$ leaf $\mathrm{h}^{-1}$ ), $\mathrm{V}$ is the chamber volume (L), A is the leaf area $\left(\mathrm{cm}^{2}\right), \mathrm{P}$ is the atmospheric pressure $\left(\mathrm{Pa}=\mathrm{N} \mathrm{m}^{-2}\right), \mathrm{R}$ is the ideal gas constant (8.314 $\mathrm{N} \mathrm{m} \mathrm{mol}^{-1} \mathrm{~K}^{-1}$ ), $\mathrm{T}$ is the temperature $(\mathrm{K}), \mathrm{M}$ is the molar mass of ${ }^{13} \mathrm{CH}_{4}$ (ng ${ }^{13} \mathrm{CH}_{4} \mathrm{~mol}^{-1}$ ), $\mathrm{f}$ is a conversion factor $\left(10^{-9} \mathrm{~m}^{3} \mu \mathrm{L}^{-1}\right)$, and ${ }^{13} \mathrm{CH}_{4}$ gcc $\left(\mu \mathrm{L}^{13} \mathrm{CH}_{4} \mathrm{~L}^{-1} \mathrm{~h}^{-1}\right)$ as defined above.

\subsection{Bromeliad abundance sampling}

We quantified the abundance of tank bromeliads in six plots $(n=6)$ of $20 \times 20 \mathrm{~m}$ using tank-diameter classes of $5 \mathrm{~cm}$ intervals and omitting juveniles with $<10 \mathrm{~cm}$ diameter. Counting the bromeliads was done from the ground using binoculars. Based on plant architecture and ecological niche preferences, we distinguished three principal functional types of tank bromeliads for field counts, gas analyses, and subsequent extrapolation of methane emissions. Type I bromeliads ('ephemeral tank' type, 
(Pittendrigh 1948)) comprise all local members of the genera Guzmania (e.g. G. confusa, G. kilipiana, G. morreniana, G. squarrosa) and Vriesea rubrobracteata. These bromeliads are all characterised by rather few, soft and very long, tapeoid (ligamentous) leaves that impound relatively small quantities of water but rather large amounts of litter in their shallow axils. Locally, Type I bromeliads are concentrated in the understory, where they occur both epiphytically and on the ground. Type II bromeliads ('absorbing trichome tank' type (Pittendrigh 1948)) represent the classic tank bromeliad and locally comprise numerous species in the genera Racinaea and Tillandsia (e.g. $R$. nervibractea, $R$. tetrantha, T. bongarana, T. complanata, T. tovariensis). Type II bromeliads have rather wide, dense, short and thick leaves capable of impounding large quantities of water. Type III bromeliads (Vriesea appendiculata, V. incurva, $V$. tequendamae); 'intermediate atmospheric tank' type (Pittendrigh 1948)) can also hold substantial amounts of water in rather small but deep and numerous axils of narrow, stiff leaves densely covered by shielded trichomes. Type II and III bromeliads are common in mid-storey and especially in over-storey but are scarce in lower strata.

\subsection{Extrapolation}

We observed an exponential relationship between $\mathrm{CH}_{4}$ emission rates and tank diameters for each functional type of tank bromeliads. The predictor functions (derived from linear mixed effects models) were the following:

Plant type I:

(1) $\quad \mathrm{E}=\exp (-37.69) * \exp (2.24 * \log (\mathrm{D})) * \exp (3.47 * \mathrm{~T}) * \exp \left(-0.1 * \mathrm{~T}^{\wedge} 2\right)$

Plant type II:

$$
\mathrm{E}=\exp (-36.74) * \exp (2.24 * \log (\mathrm{D})) * \exp (3.47 * \mathrm{~T}) * \exp \left(-0.1 * \mathrm{~T}^{\wedge} 2\right)
$$


Plant type III:

(3) $\quad \mathrm{E}=\exp (-37.62) * \exp (2.24 * \log (\mathrm{D})) * \exp (3.47 * \mathrm{~T}) * \exp \left(-0.1 * \mathrm{~T}^{\wedge} 2\right)$

$\mathrm{E}$ is the $\mathrm{CH}_{4}$ emission of the tank bromeliad $\left(\mu \mathrm{g} \mathrm{CH}_{4} \operatorname{tank}^{-1} \mathrm{~h}^{-1}\right)$, D is the median tank diameter $(\mathrm{cm})$, and $\mathrm{T}$ is the tank water temperature $\left({ }^{\circ} \mathrm{C}\right)$. Predicted methane emissions and $95 \%$ confidence intervals were obtained directly from the fitted model by setting explanatory variables to fixed values and deriving estimates at these fixed values. For extrapolation the average tank water temperature of $17^{\circ} \mathrm{C}$ was used $(0.1$ s.e.m., $\mathrm{n}=112$ ). Using these equations, we extrapolated the tank bromeliad-based $\mathrm{CH}_{4}$ emission rate to the ecosystem level (ha) by multiplying the $\mathrm{CH}_{4}$ emission of every plant size class by its abundance for each of the three functional types (Table 3). Upper and lower prediction limits were obtained by multiplying upper and lower 95\% confidence limits per plant size class and functional type with the corresponding plant abundance. Abundances were assumed to have been measured without error.

\subsection{Statistics}

We used linear mixed-effects models fit by maximum likelihood for data analysis. Response and explanatory variables were log-transformed to meet the assumptions of variance normality and homogeneity. The transformation of the response variable was chosen by maximum likelihood of the parameter of the Box-Cox power transformation. The 12 sampling trees and individual plants (numbered consecutively by sampling time) were included as random effects. The fixed effects structure was either (i) tank diameter $\mathrm{x}$ plant functional type or (ii) as (i) but including temperature and its quadratic term. Models were simplified based on Akaike's information criterion corrected for small sample sizes.

Heteroscedasticity was modeled using exponential variance functions with tank diameter as a variance covariate. The residuals showed no significant autocorrelation. 
There was no indication of collinearity (as indicated by variance inflation factors). Analyses with data averaged across the 12 sampling trees and the 3 plant functional types $(\mathrm{N}=36)$ yielded very similar results. Predicted methane emissions and 95\% confidence intervals were obtained directly from the fitted model by setting explanatory variables to fixed values and deriving estimates at these fixed values. 


\section{RESUlTS AND DisCUSSION}

Tank bromeliads are common epiphytes throughout neotropical forests and early successional vegetation. Their leaves are densely arranged around an erect, compressed shoot and effectively collect water and leaf litter in bulgy, tightly sealed bases (Figure 1, 2).

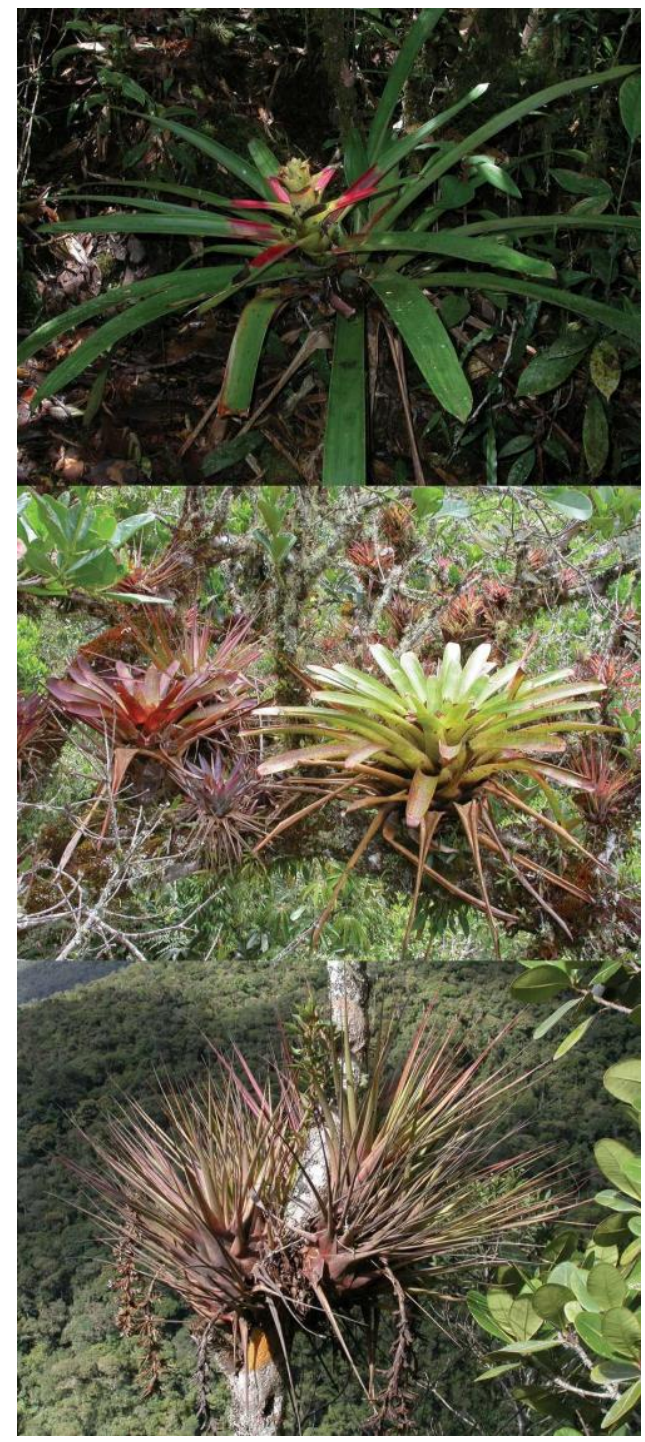

Figure 1. Three functional types of bromeliads: 'Ephemeral tank' (type I, top), 'absorbing trichome tank' (type II, centre), and 'intermediate atmospheric tank' (type III, bottom). All three functional types represent ecological type 4 in Benzing's classification scheme (Benzing 2000) (Photographs from F. Werner). 
We measured $\mathrm{CH}_{4}$ fluxes from tank bromeliads of three functional plant types (Figure 1) with various sizes and from different strata of a moist tropical montane forest at the Reserva Biológica San Francisco ( $03^{\circ} 58^{\prime}$ S, 79 $04^{\prime}$ W), located on the eastern slope of the Ecuadorian Andes at an altitude of $2100 \mathrm{~m}$ above sea level. Mean temperature at $1960 \mathrm{~m}$ was $15.5^{\circ} \mathrm{C}$, and annual precipitation was $2130 \mathrm{~mm}$ with low seasonality.

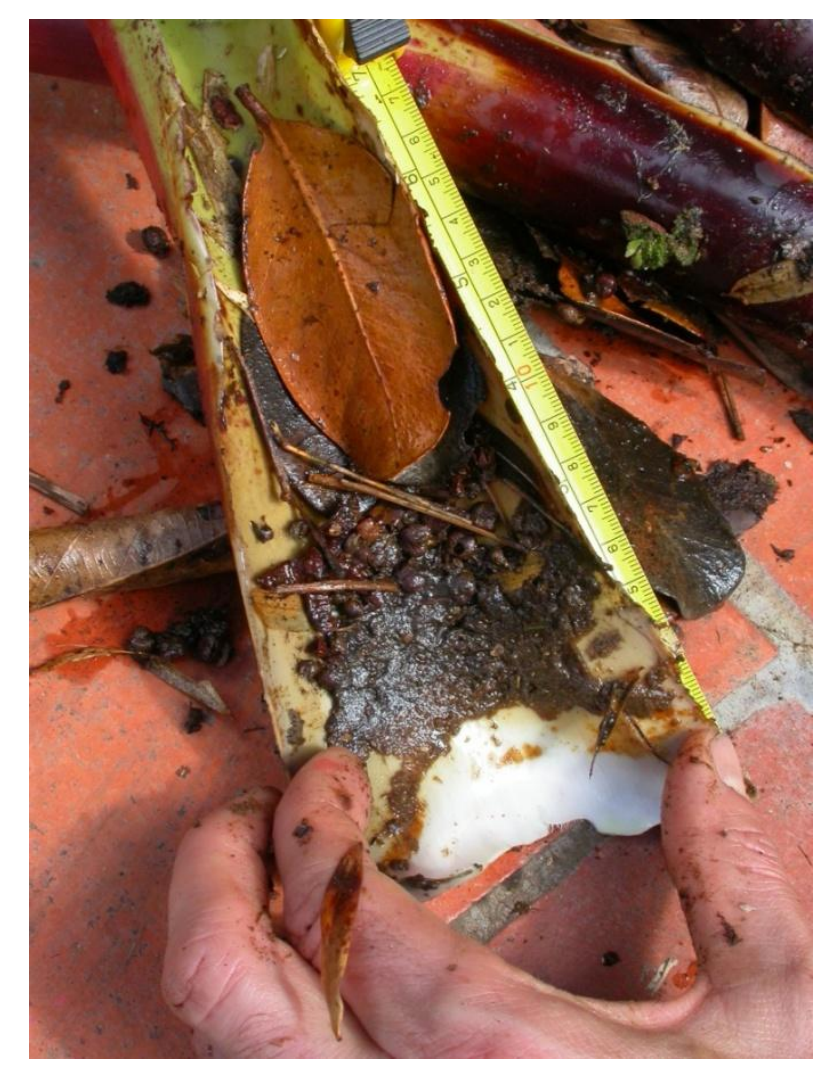

Figure 2. Leaf litter and organic debris in the leaf axil of a tank bromeliad (Tillandsia tovariensis), (Photograph from F. Werner)

We found that all tank bromeliads $(\mathrm{n}=167)$ emitted $\mathrm{CH}_{4}$. Each functional bromeliad type showed an exponential relationship between $\mathrm{CH}_{4}$ emission rates and tank diameters $(\mathrm{P}<0.0001$; residual d.f.=152) (Figure 3). Type I bromeliads showed lower $\mathrm{CH}_{4}$ emission than type II bromeliads ( $\left.\mathrm{P}<0.0001\right)$, while types II and III bromeliads did not differ significantly. 


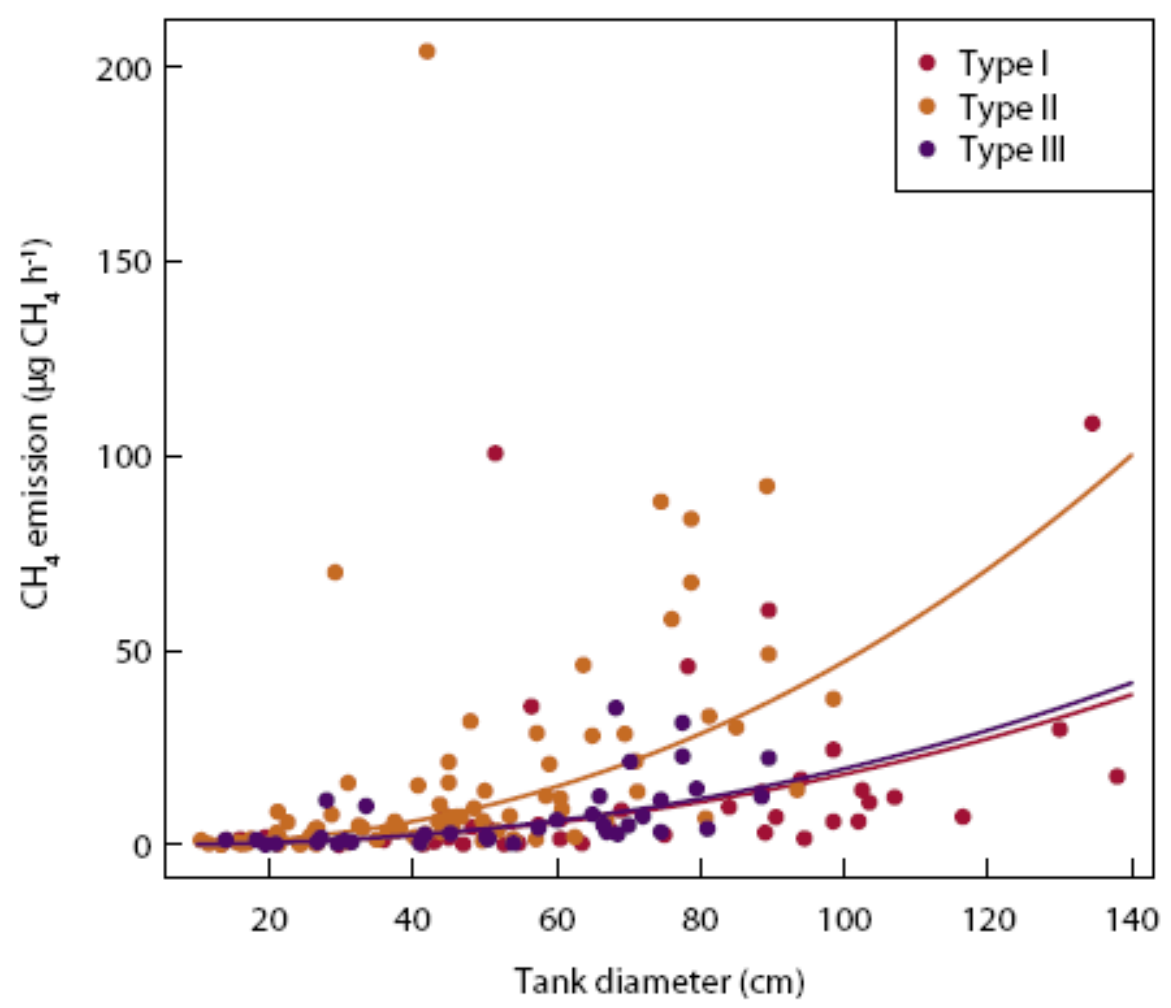

Figure 3. Methane emissions from the three functional types of bromeliads in relation to bromeliad tank diameters. We fitted an exponential function for every bromeliad functional type. Ranges of methane emissions were: 0.001-108.4 $\mu \mathrm{g} \mathrm{CH}_{4} \mathrm{~h}^{-1}$ for type I (red points), 0.08-204.1 $\mu \mathrm{g}$ $\mathrm{CH}_{4} \mathrm{~h}^{-1}$ for type II (orange points), and 0.05-35.19 $\mu \mathrm{CH}_{4} \mathrm{~h}^{-1}$ for type III (purple points)

The methanogenic community was analysed in the tank content of 53 bromeliads. Terminal restriction fragment length polymorphism (T-RFLP) of the archaeal 16S rRNA showed patterns that were characteristic of diverse communities of methanogenic Archaea. The most commonly observed terminal restriction fragments (T-RFs) had sizes of 84, 92, 186, 284 and 393 base pair (bp) length (Table 1). T-RFs with other sizes accounted for less than $8 \%$ of the total. Previous studies (Conrad et al. 2008) have shown that these T-RFs were characteristic for the following archaeal phyla: Methanomicrobiales (84 bp and 393 bp), Methanobacteriales (92 bp), Methanosaetaceae (284 bp), Methanocellales (Rice cluster I) (393 bp), and non-methanogenic Crenarchaeota (186 bp). Clone sequences obtained from 5 different tank bromeliads confirmed this phylogenetic association (Figure 4). The relative abundance of the individual T-RFs in the different bromeliads varied considerably, but the average 
abundance of the T-RFs across the different bromeliads was on the same order of magnitude as that of the clone sequences. T-RFLP analysis and clone sequencing thus showed that tank bromeliads contained various methanogenic phyla including both hydrogenotrophic (Methanomicrobiales (including Fen cluster), Methanobacteriales, Methanocellales) and acetotrophic (Methanosaeataceae) methanogens so that complete degradation of organic matter to $\mathrm{CH}_{4}$ and $\mathrm{CO}_{2}$ is in principle possible if the detected methanogens were active. However, Methanosarcinaceae, which are common in flooded soils (Conrad et al. 2008), were not detected. A similar spectrum of methanogenic taxa was recently reported for lake sediments in Amazonia (Conrad et al. 2010).

Table 1. Relative abundance of methanogenic archaea (mean \pm standard deviation) in the tank water of 53 bromeliads, determined by terminal restriction fragment (T-RF) length polymorphism analysis of the archaeal $16 \mathrm{~S}$ rRNA gene and phylogenetic analysis of archaeal 16S rRNA gene sequences (using $\mathbf{n}=150$ clones from 5 different bromeliads).

\begin{tabular}{llll}
\hline $\begin{array}{l}\text { T-RF } \\
\text { length } \\
\text { (base pair) }\end{array}$ & $\begin{array}{l}\text { T-RF } \\
(\%)\end{array}$ & $\begin{array}{l}\text { abundance } \\
\text { of clone sequences }\end{array}$ & $\begin{array}{l}\text { Sequence affiliation } \\
(\%)\end{array}$ \\
\hline 84 & $4.7 \pm 9.3$ & 8.0 & Methanogenic archaea \\
92 & $35.4 \pm 22.6$ & 25.3 & Methanobacteriales \\
186 & $23.3 \pm 19.1$ & 18.0 & Crenarchaeota \\
284 & $3.2 \pm 4.7$ & 5.3 & Methanosaetaceae \\
393 & $26.0 \pm 19.9$ & 34.0 & Methanomicrobiales, \\
& & & Methanocellales \\
\hline Total & 92.6 & 90.6 & \\
\hline
\end{tabular}




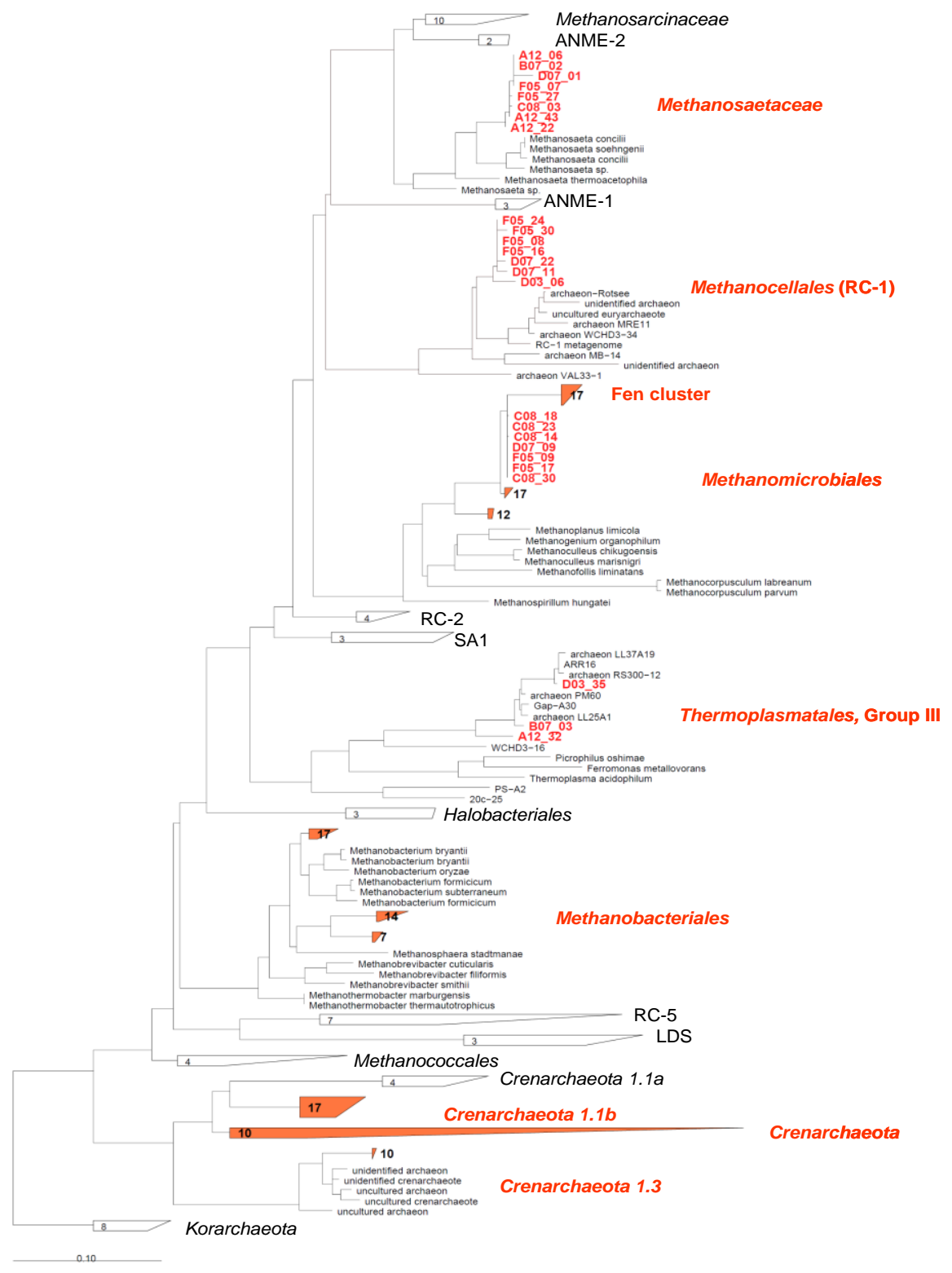

Figure 4. Phylogenetic tree of archaeal 16S rRNA gene sequences retrieved from five different tank bromeliads (A12, B07, C08, D03, F05). The clone sequences retrieved are shown in bold and red color. In some cases similar clone sequences were collapsed, just showing the number of clones retrieved in bold face and red color. The Fen Cluster within the Methanomicrobiales was identified by the sequences of isolates 6A and NTA (Brauer et al. 2006). The scale bar indicates $10 \%$ sequence divergence.

Dissolved $\mathrm{CH}_{4}$ concentration of bromeliad tank water samples ranged from 2.9 to $37.3 \mu \mathrm{g} \mathrm{CH}_{4} \mathrm{~L}^{-1}$. All samples were supersaturated, amounting to 97-1243 times the 
equilibrium concentration with the atmosphere $\left(0.03 \mu \mathrm{g} \mathrm{CH}_{4} \mathrm{~L}^{-1}\right.$ at $\left.25^{\circ} \mathrm{C}\right)$. The high $\mathrm{CH}_{4}$ emission from the bromeliad tanks cannot be explained by diffusion from water to air. According to Fick's law, the diffusion of $\mathrm{CH}_{4}$ through the water surface of bromeliad tanks would require a surface of ca. $0.1 \mathrm{~m}^{2}( \pm 0.03$ s.e.m., $\mathrm{n}=6)$ to account for the total flux from a bromeliad - a manifold of the actual tank water surface. Bubbling can also not explain the high emission rates, since $\mathrm{CH}_{4}$ concentrations in the incubation chambers always increased linearly with closure time rather than abruptly as is the case for bubble-released $\mathrm{CH}_{4}$.

To test if leaf tissue serves as conduit for $\mathrm{CH}_{4}$, we measured emission rates from distal sections of bromeliad leaves. Methane emissions averaged $2.4 \mathrm{ng} \mathrm{CH}_{4} \mathrm{~cm}^{-2} \mathrm{leaf} \mathrm{h}^{-1}$ ( \pm 0.9 s.e.m., $\mathrm{n}=6$ ), indicating that $\mathrm{CH}_{4}$ was diffusing via the bromeliad leaf structure. This pathway was confirmed in a ${ }^{13} \mathrm{CH}_{4}$ tracer experiment (Table 2). Labelled ${ }^{13} \mathrm{CH}_{4}$ dissolved in the tank water was emitted through the leaves in all of the tested plants. Methane transport through leaves is commonly found in aquatic plants, which use different mechanisms to facilitate gas transport between the atmosphere and their roots (Armstrong 1979, Grosse et al. 1991, Schuetz et al. 1991). However, the exact path of $\mathrm{CH}_{4}$ through bromeliad leaves remains unclear. A possible pathway from the tank into the leaf tissue is in dissolved form via active water transportation through absorptive foliar hairs (trichomes). Tank bromeliads use foliar trichomes to actively absorb and transport tank water, dissolved nutrients and even organic molecules as large as amino acids through the cuticle into the leaf (Benzing 2000, Benzing et al. 1985, Pierce et al. 2001). Bromeliad leaves are pervaded by regular, unbroken and wide strands of aerenchyma that connect the water-impounding basal sections with the photosynthetically active central and distal sections of the leaves and stomata (Tomlinson 1969). Once dissolved $\mathrm{CH}_{4}$ has entered the leaf tissue, it should readily diffuse into the aerenchyma. The tillandsioid bromeliads that form the entire waterimpounding bromeliad flora at our study site exhibit $\mathrm{C}_{3}$-type photosynthesis and only rarely and facultatively CAM-cycle, so that stomata should generally be open during daytime unless plants are under substantial water stress (Benzing 2000). 
Table $2 .{ }^{13} \mathrm{CH}_{4}$ tracer experiment with three bromeliad individuals.

$\begin{array}{clrl}\text { Leaf area inserted } & \text { Initial } & \mathrm{CH}_{4} & \text { Initial } \\ \text { into a leaf chamber } & { }^{13} \mathrm{C} \\ \text { concentration } & \text { in abundance of } \\ \text { leaf chamber } & \begin{array}{l}\mathrm{CH}_{4} \text { in leaf } \\ \text { chamber }\end{array}\end{array}$

Species

chamber

\begin{tabular}{llll}
\cline { 2 - 4 } & $\left(\mathrm{cm}^{2}\right)$ & $\left(\mu \mathrm{L} \mathrm{CH}_{4} \mathrm{~L}^{-1}\right)$ & (atom $\left.\%{ }^{13} \mathrm{C}\right)$ \\
\hline Guzmania melinonis & 201.69 & 2.3369 & 1.07 \\
Tillandsia guatemalensis & 187.77 & 2.3664 & 1.06 \\
Tillandsia viridiflora & 158.47 & 2.4997 & 1.03 \\
\hline
\end{tabular}

Table 2 continued

\begin{tabular}{llll}
\hline $\begin{array}{l}\mathrm{CH}_{4} \text { concentration in } \\
\text { leaf chamber at } 215 \\
\text { minutes }\end{array}$ & $\begin{array}{l}{ }^{13} \mathrm{C} \text { abundance } \\
\text { of } \mathrm{CH}_{4} \text { in leaf } \\
\text { chamber at } 215 \\
\text { minutes }\end{array}$ & $\begin{array}{l}\mathrm{CH}_{4} \text { leaf } \text { outside the } \\
\text { chamber at } \\
215 \text { minutes }\end{array}$ \\
\hline$\left(\mu \mathrm{L} \mathrm{CH}_{4} \mathrm{~L}^{-1}\right)$ & $\left(\right.$ atom $\left.\%{ }^{13} \mathrm{C}\right)$ & (atom $\left.\%{ }^{13} \mathrm{C}\right)$ & $\left(\mathrm{ng}^{13} \mathrm{CH}_{4} \mathrm{~cm}^{-2} \mathrm{leafh}^{-1}\right)$ \\
\hline 2.5389 & 2.81 & 1.05 & 0.11 \\
3.3783 & 12.15 & 1.11 & 1.00 \\
2.7715 & 8.67 & 1.05 & 0.66 \\
\hline
\end{tabular}

The density of bromeliads at our study site, excluding early juveniles, averaged $25.5 \times 10^{3} \mathrm{ha}^{-1}\left( \pm 7 \times 10^{3}\right.$ s.e.m., $\left.\mathrm{n}=6\right)$. This number is a conservative estimate of bromeliad abundance because we counted bromeliads from the ground where many canopy bromeliads were not easily visible. Nevertheless, our estimate is within the range of estimates from other neotropical montane forests. For example, forest plots at 550-3200 $\mathrm{m}$ in Colombia had $78.5 \times 10^{3}$ bromeliads ha-1 $\left( \pm 17 \times 10^{3}\right.$ s.e.m., $\mathrm{n}=28$ ) (Sugden \& Robins 1979).

Extrapolated $\mathrm{CH}_{4}$ emissions from tank bromeliads amount to $3.6 \mathrm{~g} \mathrm{CH}_{4} \mathrm{ha}^{-1} \mathrm{~d}^{-1}$ at our study site (Table 3). The forest soil at the study site consistently acted as a sink for atmospheric $\mathrm{CH}_{4}$ with an average $\mathrm{CH}_{4}$ uptake over 4 months of $3.1 \mathrm{~g} \mathrm{CH}_{4}$ ha-1 $^{-1} \mathrm{~d}^{-1}( \pm 0.6$ s.e.m, $n=3$ ), which is in the range of other estimates from tropical montane forest soils 
(Dutaur \& Verchot 2007, Purbopuspito et al. 2006). Extrapolating the $\mathrm{CH}_{4}$ emission from tank bromeliads to the $9.5 \times 10^{6} \mathrm{~km}^{2}$ of neotropical forests (Gragson 1992) yields a global source strength of $1.2 \mathrm{Tg} \mathrm{CH}_{4} \mathrm{yr}^{-1}$. This estimate should be further refined by future measurements in neotropical lowland forests. Estimates of bromeliad densities in lowland forests have been limited so far but appear to be lower than in montane forests. On the other hand, our initial measurements from a premontane forest at $1000 \mathrm{~m}$ in the Ecuadorian Andes, $6^{\circ} \mathrm{C}$ warmer than our study site, showed approximately ten times larger $\mathrm{CH}_{4}$ emission rates per tank bromeliad. Hence, it is possible that lowland forests generate substantial $\mathrm{CH}_{4}$ emissions in spite of their lesser bromeliad density. 
Table 3. Bromeliad densities, $\mathrm{CH}_{4}$ emission from single bromeliad tanks with lower and upper $95 \%$ confidence limits and resulting $\mathrm{CH}_{4}$ ecosystem emission from bromeliads with lower and upper prediction limits. Summing up total ecosystem emission of all tank size classes amounted to $3.6 \mathrm{~g} \mathrm{CH}_{4} \mathrm{ha}^{-1} \mathrm{~d}^{-1} \mathrm{with}$ a lower prediction limit of $2.2 \mathrm{~g} \mathrm{CH}_{4} \mathrm{ha}^{-1} \mathrm{~d}^{-1}$ and an upper prediction limit of $5.8 \mathrm{~g} \mathrm{CH}_{4} \mathrm{ha}^{-1} \mathrm{~d}^{-1}$.

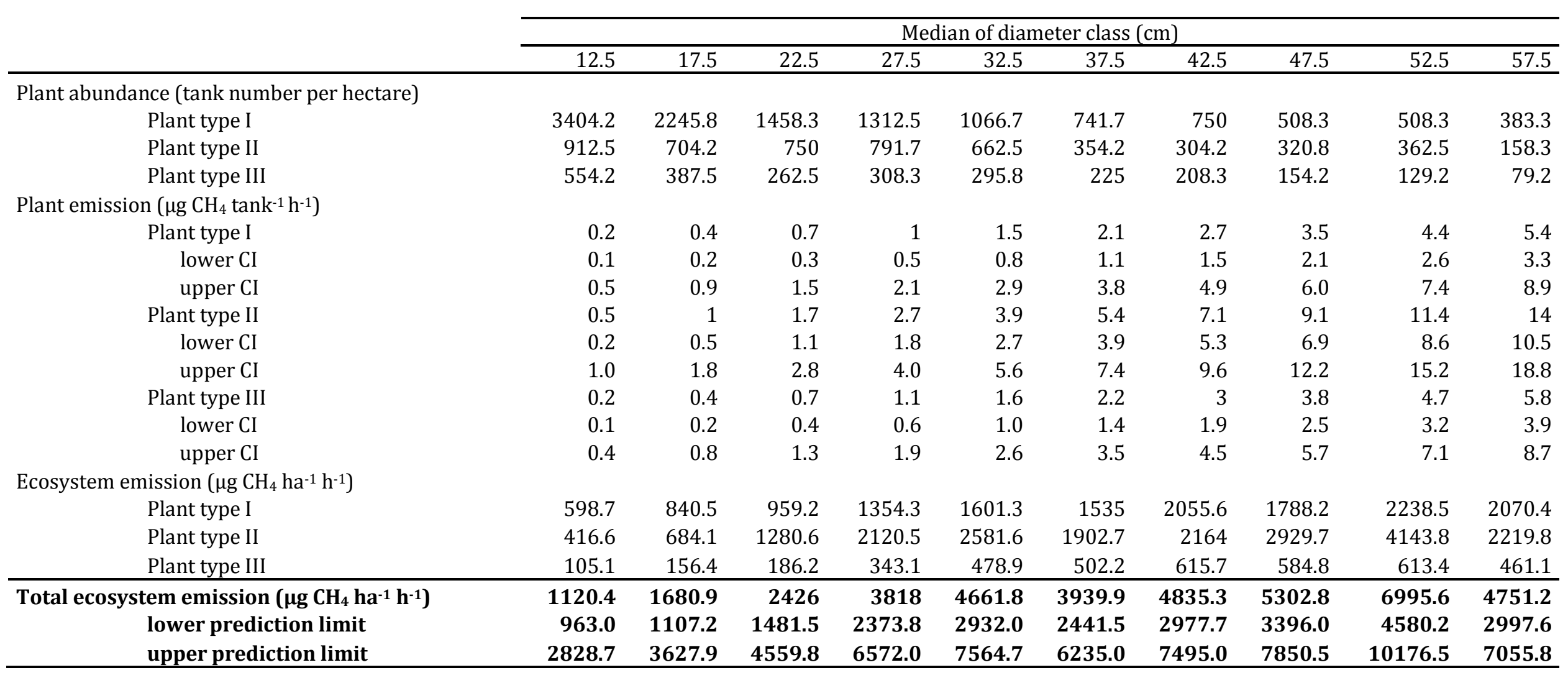


Table 3 continued

\begin{tabular}{|c|c|c|c|c|c|c|c|c|c|c|c|c|c|c|}
\hline \multicolumn{15}{|c|}{ Median of diameter class $(\mathrm{cm})$} \\
\hline 62.5 & 67.5 & 72.5 & 77.5 & 82.5 & 87.5 & 92.5 & 97.5 & 102.5 & 107.5 & 112.5 & 117.5 & 122.5 & 127.5 & 132.5 \\
\hline 412.5 & 383.3 & 420.8 & 300 & 408.3 & 300 & 320.8 & 204.2 & 237.5 & 191.7 & 129.2 & 112.5 & 70.8 & 45.8 & 54.2 \\
\hline 225 & 116.7 & 112.5 & 100 & 116.7 & 70.8 & 54.2 & 45.8 & 45.8 & 29.2 & 16.7 & 29.2 & 20.8 & 4.2 & 20.8 \\
\hline 54.2 & 41.7 & 25 & 16.7 & 25 & 16.7 & 12.5 & 8.3 & 4.2 & 8.3 & 12.5 & 0 & 4.2 & 4.2 & 4.2 \\
\hline 6.5 & 7.7 & 9.1 & 10.6 & 12.1 & 13.9 & 15.7 & 17.7 & 19.8 & 22 & 24.4 & 26.9 & 29.5 & 32.3 & 35.2 \\
\hline 4.0 & 4.8 & 5.7 & 6.7 & 7.7 & 8.8 & 10.0 & 11.2 & 12.5 & 13.8 & 15.3 & 16.7 & 18.2 & 19.8 & 21.4 \\
\hline 10.5 & 12.4 & 14.4 & 16.6 & 19.1 & 21.8 & 24.7 & 27.8 & 31.2 & 34.9 & 38.9 & 43.1 & 47.7 & 52.5 & 57.7 \\
\hline 16.9 & 20.1 & 23.6 & 27.4 & 31.5 & 36 & 40.7 & 45.9 & 51.3 & 57.1 & 63.2 & 69.7 & 76.5 & 83.7 & 91.3 \\
\hline 12.5 & 14.6 & 16.8 & 19.2 & 21.7 & 24.3 & 27.0 & 29.8 & 32.7 & 35.7 & 38.9 & 42.1 & 45.5 & 48.9 & 52.5 \\
\hline 22.9 & 27.7 & 33.0 & 39.1 & 45.8 & 53.3 & 61.6 & 70.6 & 80.5 & 91.2 & 102.8 & 115.3 & 128.8 & 143.2 & 158.7 \\
\hline 7 & 8.3 & 9.8 & 11.4 & 13.1 & 14.9 & 16.9 & 19 & 21.3 & 23.7 & 26.3 & 29 & 31.8 & 34.8 & 37.9 \\
\hline 4.7 & 5.6 & 6.5 & 7.5 & 8.5 & 9.6 & 10.7 & 11.9 & 13.1 & 14.4 & 15.8 & 17.1 & 18.6 & 20.0 & 21.6 \\
\hline 10.5 & 12.5 & 14.8 & 17.3 & 20.2 & 23.3 & 26.7 & 30.5 & 34.6 & 39.0 & 43.8 & 48.9 & 54.5 & 60.4 & 66.7 \\
\hline 2686.3 & 2966.9 & 3823.7 & 3165.9 & 4958.1 & 4156.9 & 5035.9 & 3606.5 & 4693.6 & 4215.1 & 3145.7 & 3020.6 & 2088.3 & 1478.2 & 1904.4 \\
\hline 3803.5 & 2344 & 2653.4 & 2739.3 & 3677.3 & 2547.8 & 2207 & 2101.7 & 2351.3 & 1665 & 1053.6 & 2032.9 & 1594.4 & 348.8 & 1901.4 \\
\hline 380.4 & 347.8 & 244.9 & 189.7 & 327.3 & 249 & 211.6 & 158.7 & 88.8 & 197.6 & 328.3 & 0 & 132.5 & 144.9 & 158 \\
\hline 6870.2 & 5658.7 & 6722.1 & 6094.9 & 8962.7 & 6953.6 & 7454.5 & 5866.9 & 7133.7 & 6077.8 & 4527.6 & 5053.5 & 3815.2 & 1971.9 & 3963.8 \\
\hline 4522.4 & 3602.7 & 4333.3 & 3946.1 & 5710.1 & 4382.5 & 4678.4 & 3662.1 & 4470.8 & 3706.1 & 2632.1 & 3110.0 & 2240.6 & 1116.5 & 2257.3 \\
\hline 10063.5 & 8486.3 & 10142.1 & 9185.9 & 13642.2 & 10689.9 & 11583.9 & 9168.9 & 11251.3 & 9682.4 & 7288.8 & 8220.9 & 6283.8 & 3261.3 & 6707.8 \\
\hline
\end{tabular}

Table 3 continued 


\begin{tabular}{|c|c|c|c|c|c|c|c|c|c|c|c|}
\hline \multicolumn{12}{|c|}{ Median of diameter class $(\mathrm{cm})$} \\
\hline 137.5 & 142.5 & 147.5 & 152.5 & 157.5 & 162.5 & 167.5 & 172.5 & 177.5 & 187.5 & 192.5 & 197.5 \\
\hline 25 & 41.7 & 12.5 & 20.8 & 8.3 & 12.5 & 20.8 & 33.3 & 12.5 & 16.7 & 8.3 & 4.2 \\
\hline 12.5 & 12.5 & 12.5 & 8.3 & 0 & 0 & 16.7 & 8.3 & 4.2 & 4.2 & 0 & 0 \\
\hline 8.3 & 0 & 4.2 & 4.2 & 0 & 0 & 0 & 0 & 0 & 0 & 0 & 0 \\
\hline 38.2 & 41.4 & 44.7 & 48.2 & 51.8 & 55.6 & 59.5 & 63.6 & 67.8 & 76.6 & 81.3 & 86.1 \\
\hline 23.1 & 24.8 & 26.6 & 28.4 & 30.3 & 32.3 & 34.2 & 36.3 & 38.3 & 42.6 & 44.9 & 47.1 \\
\hline 63.2 & 69.0 & 75.2 & 81.7 & 88.6 & 95.8 & 103.4 & 111.4 & 119.8 & 137.7 & 147.3 & 157.3 \\
\hline 99.2 & 107.5 & 116.1 & 125.1 & 134.5 & 144.3 & 154.4 & 165 & 175.9 & 198.9 & 211 & 223.5 \\
\hline 56.2 & 59.9 & 63.8 & 67.8 & 71.9 & 76.0 & 80.3 & 84.7 & 89.2 & 98.4 & 103.2 & 108.0 \\
\hline 175.1 & 192.6 & 211.2 & 230.9 & 251.8 & 273.8 & 297.0 & 321.4 & 347.0 & 402.1 & 431.6 & 462.5 \\
\hline 41.2 & 44.6 & 48.2 & 52 & 55.9 & 59.9 & 64.2 & 68.5 & 73.1 & 82.6 & 87.7 & 92.9 \\
\hline 23.1 & 24.7 & 26.4 & 28.1 & 29.8 & 31.6 & 33.5 & 35.3 & 37.3 & 41.2 & 43.3 & 45.4 \\
\hline 73.4 & 80.6 & 88.2 & 96.2 & 104.7 & 113.6 & 123.0 & 132.9 & 143.3 & 165.7 & 177.6 & 190.1 \\
\hline 955.2 & 1724.8 & 559.1 & 1004.2 & 431.8 & 694.8 & 1239.5 & 2118.5 & 847 & 1277.2 & 677.4 & 358.8 \\
\hline 1239.7 & 1343.2 & 1451.2 & 1042.6 & 0 & 0 & 2573.9 & 1374.8 & 732.9 & 828.8 & 0 & 0 \\
\hline 343.3 & 0 & 201 & 216.6 & 0 & 0 & 0 & 0 & 0 & 0 & 0 & 0 \\
\hline 2538.2 & 3067.9 & 2211.3 & 2263.4 & 431.8 & 694.8 & 3813.4 & 3493.2 & 1579.9 & 2106 & 677.4 & 358.8 \\
\hline 1287.9 & 1784.6 & 1134.4 & 1158.4 & 251.7 & 403.2 & 2053.3 & 1910.5 & 853.7 & 1125.4 & 372.3 & 197.9 \\
\hline 4378.2 & 5285.8 & 3950.4 & 4019.8 & 735.0 & 1197.3 & 7110.0 & 6376.4 & 2954.5 & 3988.8 & 1222.7 & 660.8 \\
\hline
\end{tabular}




\section{CONCLUSION}

Our results show that bromeliads contribute substantially to $\mathrm{CH}_{4}$ emissions from neotropical forests. $\mathrm{CH}_{4}$ emitted from plants, other than tank bromeliads, is produced either by chemical degradation of plant pectin (Keppler et al. 2006, Keppler et al. 2008) or in anoxic microsites in the soil and diffused only by plant organs (Nisbet et al. 2009). $\mathrm{CH}_{4}$ from bromeliad tanks differs fundamentally in that it is produced above ground in a 'canopy wetland' formed by unique structures of the plant. While tank bromeliads are restricted to the New World, other types of cryptic wetlands (e.g. hollow bamboo internodes, tree holes, non-bromeliad leaf axils, pitchers, ditches along roads, shallow depressions in the soil, ephemeral ponds) are not (Kitching 2000) and may constitute an important additional source of $\mathrm{CH}_{4}$ from tropical and subtropical forests. 


\section{REFERENCES}

Armstrong, W. 1979. Aeration in higher plants. Advances in Botanical Research 7:225332.

Benzing D. H. 2000. Bromeliaceae: profile of an adaptive radiation. Cambridge University Press, Cambridge, UK.

Benzing, D. H., T. J. Givnish, and D. Bermudes. 1985. Absorptive trichomes in Brochinia reducta (Bromeliaceae) and their evolutionary and systematic significance. Systematic Botany 10:81-91.

Brand, W. A. 1996. High precision isotope ratio monitoring techniques in mass spectrometry. Journal of Mass Spectrometry 31:225-235.

Brauer, S. L., E. Yashiro, N. G. Ueno, J. B. Yavitt, and S. H. Zinder. 2006. Characterization of acid-tolerant $\mathrm{H}_{2} / \mathrm{CO}_{2}$-utilizing methanogenic enrichment cultures from an acidic peat bog in New York State. Fems Microbiology Ecology 57:206-216.

Conrad, R. 2009. The global methane cycle: Recent advances in understanding the microbial processes involved [Minireview]. Environmental Microbiology Reports 1:285-292.

Conrad, R., M. Klose, P. Claus, and A. Enrich-Prast. 2010. Methanogenic pathway, ${ }^{13} \mathrm{C}$ isotope fractionation, and archaeal community composition in the sediment of two clearwater lakes of Amazonia. Limnology and Oceanography 55:689-702.

Conrad, R., M. Klose, M. Noll, D. Kemnitz, and P. L. E. Bodelier. 2008. Soil type links microbial colonization of rice roots to methane emission. Global Change Biology 14:657-669.

do Carmo, J. B., M. Keller, J. D. Dias, P. B. de Camargo, and P. Crill. 2006. A source of methane from upland forests in the Brazilian Amazon. Geophysical Research Letters 33. 
Dutaur, L., and L. V. Verchot. 2007. A global inventory of the soil $\mathrm{CH}_{4}$ sink. Glob.Biogeochem.Cycle 21, GB4013, doi:10.1029/2006GB002734.

Flessa, H., A. Rodionov, G. Guggenberger, H. Fuchs, P. Magdon, O. Shibistova, G. Zrazhevskaya, N. Mikheyeva, O. A. Kasansky, and C. Blodau. 2008. Landscape controls of $\mathrm{CH}_{4}$ fluxes in a catchment of the forest tundra ecotone in northern Siberia. Global Change Biology 14:2040-2056.

Frankenberg, C., P. Bergamaschi, A. Butz, S. Houweling, J. F. Meirink, J. Notholt, A. K. Petersen, H. Schrijver, T. Warneke, and I. Aben. 2008. Tropical methane emissions: A revised view from SCIAMACHY onboard ENVISAT. Geophysical Research Letters 35.

Gragson, T. L. 1992. Fishing the Waters of Amazonia - Native Subsistence Economies in a Tropical Rain-Forest. American Anthropologist 94:428-440.

Grosse, W., H. B. Buchel, and H. Tiebel. 1991. Pressurized Ventilation in Wetland Plants. Aquatic Botany 39:89-98.

Keppler, F., J. T. G. Hamilton, M. Brass, and T. Rockmann. 2006. Methane emissions from terrestrial plants under aerobic conditions. Nature 439:187-191.

Keppler, F., J. T. G. Hamilton, W. C. McRoberts, I. Vigano, M. Brass, and T. Rockmann. 2008. Methoxyl groups of plant pectin as a precursor of atmospheric methane: evidence from deuterium labelling studies. New Phytologist 178:808-814.

Kitching R. L. 2000. Food Webs and Container Habitats. Cambridge University Press, Cambridge, UK.

Loftfield, N., H. Flessa, J. Augustin, and F. Beese. 1997. Automated gas chromatographic system for rapid analysis of the atmospheric trace gases methane, carbon dioxide, and nitrous oxide. Journal of Environmental Quality 26:560-564.

Megonigal, J. P., and A. B. Guenther. 2008. Methane emissions from upland forest soils and vegetation. Tree Physiology 28:491-498.

Melack, J. M., and L. L. Hess. 2009. Remote sensing of the distribution and extent of wetlands in the Amazon basin. in W. J. Junk, and M. Piedade editors. Amazonian 
Floodplain Forests: Ecophysiology, Ecology, Biodiversity and Sustainable Management. Springer, New York.

Nisbet, R. E. R., R. Fisher, R. H. Nimmo, D. S. Bendall, P. M. Crill, A. V. Gallego-Sala, E. R. C. Hornibrook, E. Lopez-Juez, D. Lowry, P. B. R. Nisbet, E. F. Shuckburgh, S. Sriskantharajah, C. J. Howe, and E. G. Nisbet. 2009. Emission of methane from plants. Proceedings of the Royal Society B-Biological Sciences 276:1347-1354.

Pierce, S., K. Maxwell, H. Griffiths, and K. Winter. 2001. Hydrophobic trichome layers and epicuticular wax powders in Bromeliaceae. American Journal of Botany 88:13711389.

Pittendrigh, C. S. 1948. The Bromeliad-Anopheles-Malaria complex in Trinidad.1. The bromeliad flora. Evolution 2:58.

Prather, M. 2001. Atmospheric chemistry and greenhouse gases. in J. T. Houghton editor. Climate Change 2001: The Scientific Basis, Contribution of Working Group I to the Third Assessment Report of the Intergovernmental Panel on Climate Change. Cambridge University Press, Cambridge, UK.

Purbopuspito, J., E. Veldkamp, R. Brumme, and D. Murdiyarso. 2006. Trace gas fluxes and nitrogen cycling along an elevation sequence of tropical montane forests in Central Sulawesi, Indonesia. Global Biogeochemical Cycles 20, GB3010, doi:10.1029/2005GB002516.

Schuetz, H., P. Schroeder, and H. Rennenberg. 1991. Role of plants in regulating the methane flux to the atmosphere. Pages 29-63 in T. D. Sharkey, E. A. Holland, and H. A. Mooney editors. Trace Gas Emissions by Plants. Academic Press, San Diego.

Shindell, D. T., G. Faluvegi, D. M. Koch, G. A. Schmidt, N. Unger, and S. E. Bauer. 2009. Improved Attribution of Climate Forcing to Emissions. Science 326:716-718.

Sugden, A. M., and R. J. Robins. 1979. Aspects of the ecology of vascular epiphytes in Colombian cloud forests.1. Distribution of the epiphytic flora. Biotropica 11:173188. 
Tiedje, J. M. 1982. Denitrification. Pages 1011-1026 in A. L. Page, R. H. Miller, D. R. Keeney editors. Methods of Soil Analysis, Part 2. Agronomy Monograph No. 9. American Society of Agronomy, Madison, WI, USA.

Tomlinson P. B. 1969. Anatomy of the Monocotyledons. III. Commelinales - Zingiberales. Clarendon Press, Oxford.

Wu, X. L., M. W. Friedrich, and R. Conrad. 2006. Diversity and ubiquity of thermophilic methanogenic archaea in temperate anoxic soils. Environmental Microbiology 8:394-404. 


\section{CHAPTER III}

\section{RESPONSES OF NITROUS OXIDE FLUXES AND SOIL NITROGEN CYCLING TO NUTRIENT ADDITIONS IN MONTANE FORESTS ALONG AN ELEVATION GRADIENT IN SOUTHERN ECUADOR}

Guntars Martinson ${ }^{1}$, Edzo Veldkamp ${ }^{1}$, Marife D. Corre ${ }^{1}$

${ }^{1}$ Büsgen Institute - Soil Science of Tropical and Subtropical Ecosystems, Georg-AugustUniversity of Goettingen, Buesgenweg 2, 37077 Goettingen, Germany 


\section{ABSTRACT}

Tropical montane forests are commonly limited by $\mathrm{N}$ or co-limited by $\mathrm{N}$ and $\mathrm{P}$. Projected increases in $\mathrm{N}$ deposition in tropical regions are thought to be insufficient to overcome biological $\mathrm{N}$ demand in tropical montane forests and to increase soil $\mathrm{N}$ availability and soil $\mathrm{N}_{2} \mathrm{O}$ emissions. We established a nutrientaddition experiment ( $N, P, N+P$, and control) to achieve nutrient-enriched conditions across an elevation gradient. Fertilizers were applied at the rates of 50 $\mathrm{kg} \mathrm{N} \mathrm{ha}^{-1} \mathrm{yr}^{-1}$ (in the form of urea) and $10 \mathrm{~kg} \mathrm{Pha}^{-1} \mathrm{yr}^{-1}$ (in the form of $\mathrm{NaH}_{2} \mathrm{PO}_{4}$. $2 \mathrm{H}_{2} \mathrm{O}$ with analytical grade quality) split in two equal applications. Our objective was to assess changes in net rates of soil $\mathrm{N}$ cycling and $\mathrm{N}_{2} \mathrm{O}$ fluxes under $\mathrm{N}$ and $\mathrm{P}$ additions in an old-growth premontane rain forest at $1000-\mathrm{m}$, an old-growth lower montane rain forest at 2000-m and an old-growth upper montane rainforest at 3000-m elevation.

At 1000-m elevation, where vegetation growth did not respond to $N$ and $P$ addition, net rates of soil $\mathrm{N}$ cycling and $\mathrm{N}_{2} \mathrm{O}$ emissions started to increase following $\mathrm{N}$ and $\mathrm{N}+\mathrm{P}$ addition after the first and second nutrient addition in 2008 . At the 2000-m and 3000-m elevation, where vegetation growth did not respond to nutrient additions, net rates of soil $\mathrm{N}$ cycling and $\mathrm{N}_{2} \mathrm{O}$ emissions started to increase following $\mathrm{N}$ and $\mathrm{N}+\mathrm{P}$ addition after the third and fourth nutrient application in 2009 but the effects were less pronounced at the $3000-\mathrm{m}$ elevation. Addition of $\mathrm{P}$ alone had no effect on net rates of soil $\mathrm{N}$ cycling and $\mathrm{N}_{2} \mathrm{O}$ emissions at any elevation. Our results showed that the response of net rates of soil $\mathrm{N}$ cycling and $\mathrm{N}_{2} \mathrm{O}$ fluxes to $\mathrm{N}$ - and $\mathrm{P}$-additions depended mainly on the soil $\mathrm{N}$ status at each elevation that may primarily be controlled by the presence or absence of an organic layer, hydrological properties and soil temperature and may be independent from nutrient demand by the vegetation. 


\section{INTRODUCTION}

One third of terrestrial net primary production (NPP) is generated by tropical forests (Field et al. 1998, Malhi \& Phillips 2004) and their soils are the largest natural source of nitrous oxide $\left(\mathrm{N}_{2} \mathrm{O}\right)$ globally (approximately 4.4 $\left.\mathrm{Tg} \mathrm{N} \mathrm{yr}^{-1}\right)$, produced by the microbial processes of nitrification and denitrification (IPCC 2007). Net primary production and soil microbial processes strongly depend on nutrients, as trees and microbes may need up to 25 chemical elements to grow and reproduce (Sterner \& Elser 2002). Nutrient limitation to an ecosystem process is identified by nutrient manipulation experiment; if the rate of an ecosystem process is increased by an addition of a nutrient, such process is limited by that nutrient (Tanner et al. 1998). The conceptual framework of nutrient limitation for nitrogen $(\mathrm{N})$ and phosphorus (P) as the two most common limiting nutrients in terrestrial ecosystems suggests that during soil development $\mathrm{N}$ is accumulated from the atmosphere whereas $\mathrm{P}$, which is mainly derived from geological substrate, becomes progressively unavailable during pedogenesis (Walker \& Syers 1976). As many lowland tropical forests grow on heavily weathered soils they are thought to be P limited. In contrast, most tropical montane forests grow on younger soils and are thought to be $\mathrm{N}$ limited or simultaneously $\mathrm{N}$ and $\mathrm{P}$ limited (Tanner et al. 1998). This conceptual soil-age nutrient limitation model was validated by field studies where increased NPP was observed following $\mathrm{N}$ and in some cases $\mathrm{P}$ additions to tropical montane forests (Adamek et al. 2009, Tanner et al. 1992, Tanner et al. 1990, Vitousek et al. 1993).

Tropical montane forest soils are typically covered by thick organic layers, in which considerable amounts of nutrients are stored but not actively cycling (Grubb 1977). Organic layer thickness tends to increase with elevation which is related to interaction among differences in plant species composition, soils and related nutrient availability, temperature and soil moisture, affecting quality of organic matter and rates of nutrient turnover (Arnold et al. 2009, Burghouts et al. 1998, Trumbore 2009, Wilcke et al. 2002). Several studies suggest that in these ecosystems nutrient limitations may control decomposition and ultimately $\mathrm{N}$ cycling rates. Nutrient limitation to decomposition and $\mathrm{N}$ cycling is often different from nutrient limitation to NPP. In tropical montane forests in Hawaii, leaf litter decomposition was $\mathrm{N}$ and $\mathrm{P}$ limited 
whereas stem diameter growth and leaf litterfall was only N limited (Hobbie \& Vitousek 2000). Furthermore, $\mathrm{N}$ addition to a montane forest in Panama increased not only stem diameter growth, fine litter production (Adamek et al. 2009) and soil N-cycling rates but also losses of nitrate leaching and N-oxide emissions (Corre et al. 2010). These reactions of vegetation growth, nutrient cycling and $\mathrm{N}$ losses to nutrient additions suggest that vegetation does not act as the dominant sink of added nutrient but that simultaneous increase in soil $\mathrm{N}$ cycling rates can lead to concurrent increases in $\mathrm{N}$ sink (e.g. vegetation) and losses. Most of nutrient manipulation experiments in tropical montane forests have only focused on NPP responses (Tanner et al. 1998) and only very few have investigated the effects on soil $\mathrm{N}$ cycling and the associated emissions of $\mathrm{N}_{2} \mathrm{O}$ which is a potent greenhouse gas (Hall \& Matson 1999, Koehler et al. 2009, Corre et al. 2010).

Here we evaluate how moderate rates of $\mathrm{N}$ and $\mathrm{P}$ additions $\left(50 \mathrm{~kg} \mathrm{~N} \mathrm{ha}^{-1} \mathrm{yr}^{-1}\right.$ and $10 \mathrm{~kg} \mathrm{P} \mathrm{ha-1} \mathrm{yr}^{-1}$, respectively) influence soil $\mathrm{N}$ cycling and the associated $\mathrm{N}_{2} \mathrm{O}$ fluxes along an elevation gradient of tropical montane forests. We tested the following hypotheses: 1) in tropical montane forests, the effects of $\mathrm{N}$ and $\mathrm{P}$ additions on soil $\mathrm{N}$ cycling and $\mathrm{N}_{2} \mathrm{O}$ fluxes do not commensurate with their controls on NPP, and 2) the magnitude and timing of $\mathrm{N}_{2} \mathrm{O}$ flux response depend on the initial nutrient status of the forest soil. Our objective was to assess changes in net rates of soil $\mathrm{N}$ cycling and $\mathrm{N}_{2} \mathrm{O}$ fluxes under $\mathrm{N}$ and $\mathrm{P}$ additions in forests at 1000-m, 2000-m and 3000-m elevations. Vegetation growth did not respond nutrient addition at all elevations (J. Homeier, unpublished results). In contrast, $\mathrm{N}_{2} \mathrm{O}$ fluxes and net rates of soil $\mathrm{N}$ cycling generally increased under $\mathrm{N}$ or combined $\mathrm{N}+\mathrm{P}$ additions at all elevation-sites, implying that responses of soil processes to these nutrient additions do not correspond with the response of vegetation.

\section{MATERIALS AND METHODS}

\subsection{Study area}

Our research was conducted within the Podocarpus National Park in the Cordillera del Consuelo, a part of the eastern chain of the Andes in southern Ecuador. Three study 
sites were selected along an altitudinal gradient: 990-1100 m above sea level (Bombuscaro, $4.115^{\circ} \mathrm{S}, 78.968^{\circ} \mathrm{W}$; hereafter called the $1000-\mathrm{m}$ site), 1950-2100 $\mathrm{m}$ (San Francisco, $3.982^{\circ} \mathrm{S}, 79.083^{\circ} \mathrm{W}$; hereafter called the $2000-\mathrm{m}$ site) and $2900-3050 \mathrm{~m}$ (Cajanuma, $4.110^{\circ} \mathrm{S}, 79.178^{\circ} \mathrm{W}$; hereafter called the 3000-m site; Table 1 ). Along this altitudinal gradient, mean annual temperature decreased whereas mean annual rainfall increased (Moser et al. 2007). Rainfall showed little seasonality (Emck 2008) and ambient $\mathrm{N}$ deposition from bulk precipitation ranged from 1.5 to $4.4 \mathrm{~kg} \mathrm{~N} \mathrm{ha}^{-1} \mathrm{yr}^{-1}$ in the study region (Fabian et al. 2005). Soil characteristics (see below for the sampling and analytical methods) and forest structure description are given in Tables 1 and 2. In short, the 1000-m site consists of an old-growth premontane rain forest over deeply weathered granitic rock (slopes up to 21\%); the 2000-m site consists of an old-growth lower montane rain forest over metamorphosed schist (slopes up to 17\%); and the 3000-m site consists of an old-growth upper montane rain forest over metamorphosed schist (slopes up to 26\%) (Homeier et al. 2010, Homeier et al. 2008). The mineral soil at the 1000-m site was covered by a thin layer of decomposing leaves (Ol layer) whereas a thick organic layer, consisted of an Ol layer, a fermentation layer (Of layer) and a humus layer (Oh layer), covered the mineral soils at the 2000-m and 3000-m sites. At all sites, soil characteristics were determined in November 2007 prior to first nutrient application (Table 1). In each three replicate strata per site (see details in section 2.2), we took samples from the combined Of+Oh layer (except for the 1000-m site) and the 010-cm depth mineral soil. These samples were air-dried and shipped to the laboratory of the Soil Science of Tropical and Subtropical Ecosystems (SSTSE, University of Göttingen, Germany). Sample preparation and analytical methods are the same as those described in details by Corre et al. (2010). The soils at the 1000-m and 2000-m site are classified as Cambisol and at the 3000-m site as Histosol (IUSS Working Group WRB 2006).

\subsection{Experimental design}

At each site $(1000 \mathrm{~m}, 2000 \mathrm{~m}$ and $3000 \mathrm{~m})$, we established a factorial $\mathrm{N}$ - and P-addition experiment (i.e. $\mathrm{N}, \mathrm{P}, \mathrm{N}+\mathrm{P}$, and control) in a stratified random design with three replicate plots per treatment and 20-m x 20-m area each plot. The three replicate strata covered short topographic gradients and were treated as statistical blocks, as nutrient availability and other soil factors may vary over relatively small topographic gradients 
in these forests (Wolf et al., unpublished data). Fertilizers were applied by hand at the rates of $50 \mathrm{~kg} \mathrm{~N} \mathrm{ha}^{-1} \mathrm{yr}^{-1}$ (in the form of urea) and $10 \mathrm{~kg} \mathrm{P} \mathrm{ha}^{-1} \mathrm{yr}^{-1}$ (in the form of $\mathrm{NaH}_{2} \mathrm{PO}_{4} \cdot 2 \mathrm{H}_{2} \mathrm{O}$ with analytical grade quality) split in two equal applications per year starting in February 2008. During fertilizer application, chamber bases for gas flux measurements were covered and received the exact amount of fertilizer relative to their area afterwards.

\section{$3.3 \mathrm{~N}_{2} \mathrm{O}$ flux measurements}

We measured $\mathrm{N}_{2} \mathrm{O}$ fluxes from January 2008 to September 2009 using static vented chambers. In each replicate plot, two round chamber bases (area $0.04 \mathrm{~m}^{2}$, height $0.25 \mathrm{~m}$, $\sim 0.02$ m inserted into the soil) were permanently installed along two randomly selected perpendicular transects (totaling to four chamber bases per plot), ensuring that distance to the border of the plot was at least $2 \mathrm{~m}$ to avoid edge effects. On each sampling day, a chamber hood (approx. $0.12 \mathrm{~m}$ height) was attached tightly to a chamber base, and four gas samples were taken at 2,14, 26 and 38 minutes after chamber closure and stored in pre-evacuated glass containers $(60 \mathrm{~mL})$ with stopcocks. One day after the field sampling, gas samples were transported to our laboratory located in the nearby Universidad Técnica Particular de Loja and were analyzed using a gas chromatograph (Shimadzu GC14B, Duisburg, Germany) equipped with an electron capture detector (ECD) and an autosampler (Loftfield et al. 1997). Gas concentrations were determined by comparison of integrated peak areas of samples to standard gases (320, 501, 1001 and 3003 ppb $\mathrm{N}_{2} \mathrm{O}$; Deuste Steininger GmbH, Mühlhausen, Germany). Gas fluxes were calculated from the linear increase of gas concentration in the chamber vs. time and were adjusted for the field-measured air temperature and atmospheric pressure (Koehler et al. 2009). Zero fluxes were included. As we were primarily interested in the mid- to long-term effects of nutrient enrichment on soil mineral $\mathrm{N}$, net rates of soil $\mathrm{N}$ cycling and soil $\mathrm{N}_{2} \mathrm{O}$ fluxes, we excluded any measurements within four weeks following nutrient application from our analysis. One pre-treatment measurement at each site indicated that initial $\mathrm{N}_{2} \mathrm{O}$ fluxes did not differ between the control and other treatment plots prior to the first nutrient application started. 
Table 1. Site and soil characteristics (mean $\pm S E, n=3$ ) of the forest sites across the elevation gradient, determined in November 2007 before the first nutrient application.

\begin{tabular}{|c|c|c|c|}
\hline \multirow[t]{3}{*}{ Characteristics } & \multicolumn{3}{|c|}{ Elevation $(\mathrm{m})$ site } \\
\hline & \multirow[b]{2}{*}{1000 (Bombuscaro) } & \multirow[b]{2}{*}{ Francisco) } & \multirow[b]{2}{*}{3000 (Cajanuma) } \\
\hline & & & \\
\hline $\begin{array}{l}\text { Range of height above see } \\
\text { level }(\mathrm{m})\end{array}$ & $990-1100$ & $1950-2100$ & $2900-3050$ \\
\hline Air temperature $\left({ }^{\circ} \mathrm{C}\right)$ & 19.4 & 15.7 & 9.4 \\
\hline Precipitation $\left(\mathrm{mm} \mathrm{yr}^{-1}\right)^{\mathrm{a}}$ & 2230 & 1950 & 4500 \\
\hline Soil type (FAO) & Dystric Cambisol & Stagnic Cambisol & Stagnic Histosol \\
\hline $\begin{array}{l}\text { Bulk density (from the } \\
\text { surface down to } 10-\mathrm{cm} \\
\text { depth, } \mathrm{g} \mathrm{cm}^{-3} \text { ) }\end{array}$ & $0.84(0.1)$ & $0.18(0.05)$ & $0.11(0.01)$ \\
\hline \multicolumn{4}{|l|}{$\begin{array}{l}\text { Organic layer } \\
(\mathrm{Of}+\mathrm{Oh})\end{array}$} \\
\hline Thickness (cm) & 0 & $10-30$ & $10-40$ \\
\hline $\mathrm{pH}-\mathrm{H}_{2} \mathrm{O}$ & --- & $3.7(0.1)$ & $3.61(0.6)$ \\
\hline Total C (mg C g-1) & --- & $464.4(7.4)$ & $430.8(42.9)$ \\
\hline Total N (mg N g-1) & --- & $18.4(0.2)$ & $21.4(1.8)$ \\
\hline $\mathrm{C} / \mathrm{N}$ ratio & --- & $19.2(0.4)$ & $28.5(1.9)$ \\
\hline Total P (mg P g-1) & --- & $0.5(0.3)$ & $0.7(0.5)$ \\
\hline \multicolumn{4}{|l|}{$\begin{array}{l}\text { Mineral soil layer } \\
(0-10 \mathrm{~cm})\end{array}$} \\
\hline $\mathrm{pH}-\mathrm{H}_{2} \mathrm{O}$ & $4.8(0.4)$ & $3.7(0.6)$ & $3.8(0.1)$ \\
\hline Base saturation (\%) & $5.4(1.4)$ & $6.9(2.5)$ & $10(2.2)$ \\
\hline Total C (mg C g-1) & $23.9(1.6)$ & $21.5(2.9)$ & $12.3(0.8)$ \\
\hline Total N (mg N g-1) & $2(0.1)$ & $1.2(0.2)$ & $0.8(0.1)$ \\
\hline $\mathrm{C} / \mathrm{N}$ ratio & $18.7(2.1)$ & $25.2(4.4)$ & $27.7(3.8)$ \\
\hline Total P (mg P g-1) & $0.15(0.1)$ & $0.06(0.0)$ & $0.1(0.0)$ \\
\hline
\end{tabular}

a (Moser et al. 2007) 
Table 2. Forest stand characteristics of the forest sites across the elevation gradient.

\begin{tabular}{|c|c|c|c|c|c|}
\hline \multirow{2}{*}{ Elevation (m) site } & \multicolumn{5}{|c|}{ Forest structure characteristics (trees $\leq 0.1 \mathrm{~m}$ in diameter at breast height were excluded) } \\
\hline & $\begin{array}{l}\text { Stand height } \\
(\mathrm{m})\end{array}$ & $\begin{array}{l}\text { Mean basal area } \\
\left(\mathrm{m}^{2} \mathrm{ha}^{-1}\right)\end{array}$ & $\begin{array}{l}\text { Tree density } \\
(\text { trees ha-1) }\end{array}$ & $\begin{array}{l}\text { Most abundant tree } \\
\text { families }\end{array}$ & Most abundant tree species \\
\hline 1000 - Bombuscaro & $20-25$ & 33.4 & 747.5 & Moraceae, Sapotaceae & $\begin{array}{lll}\text { Pouteria } & \text { torta, } & \text { Clarisia } \\
\text { racemosa } & & \end{array}$ \\
\hline 2000- San Francisco & $10-14$ & 22.8 & 1142.5 & $\begin{array}{l}\text { Melastomataceae, } \\
\text { Euphorbiaceae }\end{array}$ & $\begin{array}{l}\text { Graffenrieda emarginata, } \\
\text { Myrcia sp. }\end{array}$ \\
\hline 3000 - Cajanuma & $6-8$ & 25.5 & 1305.0 & Cunoniaceae, Clusiaceae & $\begin{array}{l}\text { Weinmannia elliptica, } \\
\text { Weinmannia loxensis }\end{array}$ \\
\hline
\end{tabular}




\subsection{Soil mineral N, soil moisture and net rates of soil N cycling}

Parallel to the gas sampling, four subsamples of the top 0.05-m depth (which was the mineral soil for the $1000-\mathrm{m}$ site and the Of+Oh layer for the 2000-m and 3000-m sites) were collected within one meter distance from the four chamber bases in each replicate plot. The four subsamples were pooled to represent each plot after leaves, roots and bigger stones had been removed. In the field, part of the composite sample was added to a prepared extraction bottle containing $150 \mathrm{~mL}$ of $0.5 \mathrm{M} \mathrm{K}_{2} \mathrm{SO}_{4}$ solution while the rest of the sample was stored in plastic bags for gravimetric moisture determination (drying for 24 hours at $105^{\circ} \mathrm{C}$ ) in the field station. Samples were brought to the field station and extracted within 24 hours after field sampling. After shaking the soil- $\mathrm{K}_{2} \mathrm{SO}_{4}$ bottles for 1 hour, the extracts were filtered through filter papers ( $4 \mu \mathrm{m}$ nominal pore size), frozen immediately and remained frozen during transport by air to SSTSE, where analysis was conducted. Ammonium $\left(\mathrm{NH}_{4}{ }^{+}\right)$and nitrate $\left(\mathrm{NO}_{3}{ }^{-}\right)$contents of the extracts were analyzed using continuous flow injection colorimetry (Cenco/Skalar Instruments, Breda, Netherlands). Gravimetric moisture content was expressed as the percentage of waterfilled pore space (WFPS), assuming a particle density of $2.65 \mathrm{~g} \mathrm{~cm}^{-3}$ for mineral soil and $1.4 \mathrm{~g} \mathrm{~cm}^{-3}$ for organic layer (Breuer et al. 2002).

Net rates of soil $\mathrm{N}$ cycling were measured in each replicate plot once a year (one month after the second nutrient application in September 2008 and one month after the fourth nutrient application in September 2009) using the buried bag method (Hart 2010). It was not possible to take intact soil cores because of too many roots. Thus, a composite soil sample of the top 0.05-m depth was taken in each plot as described above. One subsample was extracted immediately in the field with $0.5 \mathrm{~mol} \mathrm{~L}^{-1} \mathrm{~K}_{2} \mathrm{SO}_{4}$ to determine the initial $\mathrm{NH}_{4}{ }^{+}$and $\mathrm{NO}_{3}$ - levels $\left(\mathrm{T}_{0}\right)$. The other subsample was put into a plastic bag, reburied in the soil, incubated for ten days and afterwards extracted with 0.5 $\mathrm{mol} \mathrm{L}^{-1} \mathrm{~K}_{2} \mathrm{SO}_{4}\left(\mathrm{~T}_{1}\right)$. The plastic bag was closed with a rubber band to prevent rain coming in but not too tight to permit air exchange. Net $\mathrm{N}$ mineralization and nitrification rates were calculated as the difference between $\mathrm{T}_{1-}$ and $\mathrm{T}_{0}-\mathrm{NH}_{4}{ }^{+}+\mathrm{NO}_{3}-$ concentrations and $\mathrm{NO}_{3}{ }^{-}$concentrations, respectively. 


\subsection{Statistical analysis}

Statistical analyses were carried out on the plot mean $\mathrm{N}_{2} \mathrm{O}$ fluxes (average of four chambers per replicate plot). Data were tested for normality and heteroscedasticity and transformed if necessary. We used linear mixed effects models for analysis of timeseries data $\left(\mathrm{N}_{2} \mathrm{O}\right.$ fluxes, soil mineral $\mathrm{N}$, soil temperature and WFPS) (Crawley 2010). When testing for differences among $\mathrm{N}-, \mathrm{P}-, \mathrm{N}+\mathrm{P}$-addition and control plots, treatment was included in the model as a fixed effect and the blocks nested in time as a random effect. The significance of the fixed effect was determined based on analysis of variance (Crawley 2010). For net rates of soil N cycling, site differences (i.e. comparison among control plots of the three elevation sites) or treatment effects at each site were assessed using one-way ANOVA followed by a TukeyHSD test. Differences between the two sampling campaigns (September 2008 and September 2009) in soil N-cycling rates of the control plots at each site was assessed using Paired T test. All levels of significance were defined at $P \leq 0.05$. Analyses were conducted using R 2.10.1 (R Development Core Team, 2009).

\section{RESULTS}

\subsection{Soil temperature, moisture, mineral $\mathrm{N}, \mathrm{N}$-cycling rates and $\mathrm{N}_{2} \mathrm{O}$ fluxes from control forest soils}

Soil temperature at the top $0.05-\mathrm{m}$ depth varied between $15.0^{\circ} \mathrm{C}$ and $18.6^{\circ} \mathrm{C}$ at the 1000 $\mathrm{m}$, between $9.0^{\circ} \mathrm{C}$ and $14.4^{\circ} \mathrm{C}$ at the $2000-\mathrm{m}$ and between $2.6^{\circ} \mathrm{C}$ and $5.3^{\circ} \mathrm{C}$ at the $3000-\mathrm{m}$ site (Figure 1a). WFPS at the top 0.05-m depth varied between $56.9 \%$ and $88.5 \%$ at the $1000-\mathrm{m}$ site, between $27.6 \%$ and $61.5 \%$ at the $2000-\mathrm{m}$ site and between $17.9 \%$ and $57.8 \%$ at the $3000-\mathrm{m}$ site without any clear seasonal pattern at allevations (Figure $1 \mathrm{~b})$. 

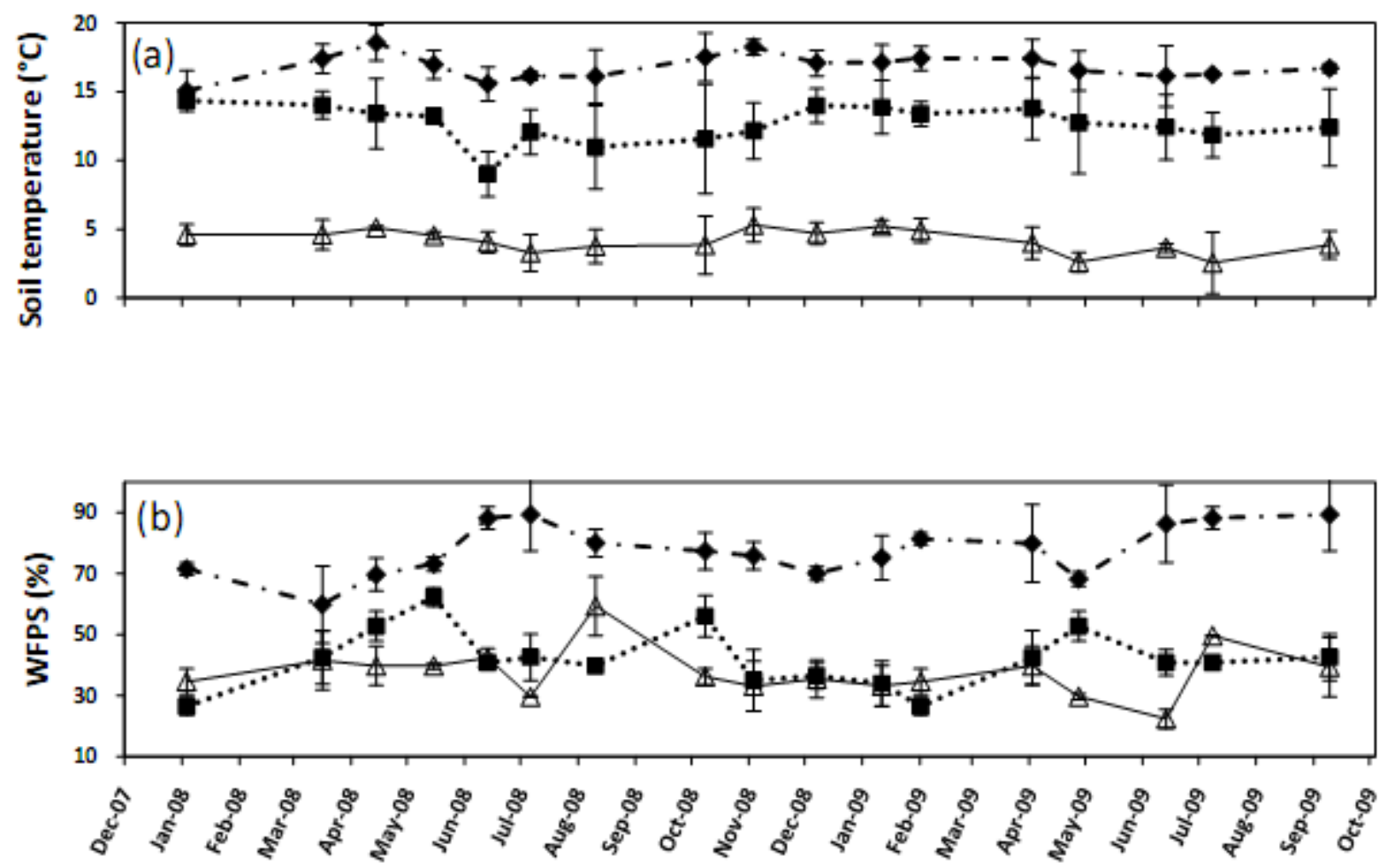

Figure 1. (a) Mean ( \pm SE, $n=3$ ) soil temperature (b) and water-filled pore space (WFPS) (b) at the top 0.05-m soil depth in control plots at the 1000-m (^), 2000-m (-) and 3000-m sites ( $(\Delta)$.

$\mathrm{NH}_{4}{ }^{+}$contents varied between 5.5 and $15.0 \mu \mathrm{g} \mathrm{cm}^{-2}$ soil at the 1000 -m site (Figure 2a), between 23.3 and $163.5 \mu \mathrm{g} \mathrm{N} \mathrm{cm}^{-2}$ soil at the 2000-m site (Figure 2b) and between 11.6 and $82.0 \mu \mathrm{g} \mathrm{N} \mathrm{cm}^{-2}$ soil at the 3000-m site (Figure 2c) without any clear seasonal pattern at all elevations. Significant amounts of nitrate $\left(\mathrm{NO}_{3}{ }^{-}\right)$were only detected at the $1000-\mathrm{m}$ site with a maximum of $11.9 \mu \mathrm{g} \mathrm{N} \mathrm{cm}{ }^{-2}$ soil (Figure 3a). $\mathrm{NO}_{3}^{-}$was often below the analytical detection limit $\left(0.10 \mathrm{mg} \mathrm{NO}_{3}-\mathrm{N} \mathrm{L}^{-1}\right)$ at the $2000-\mathrm{m}$ and $3000-\mathrm{m}$ sites (Figures $3 \mathrm{~b}$ and $3 c)$. 

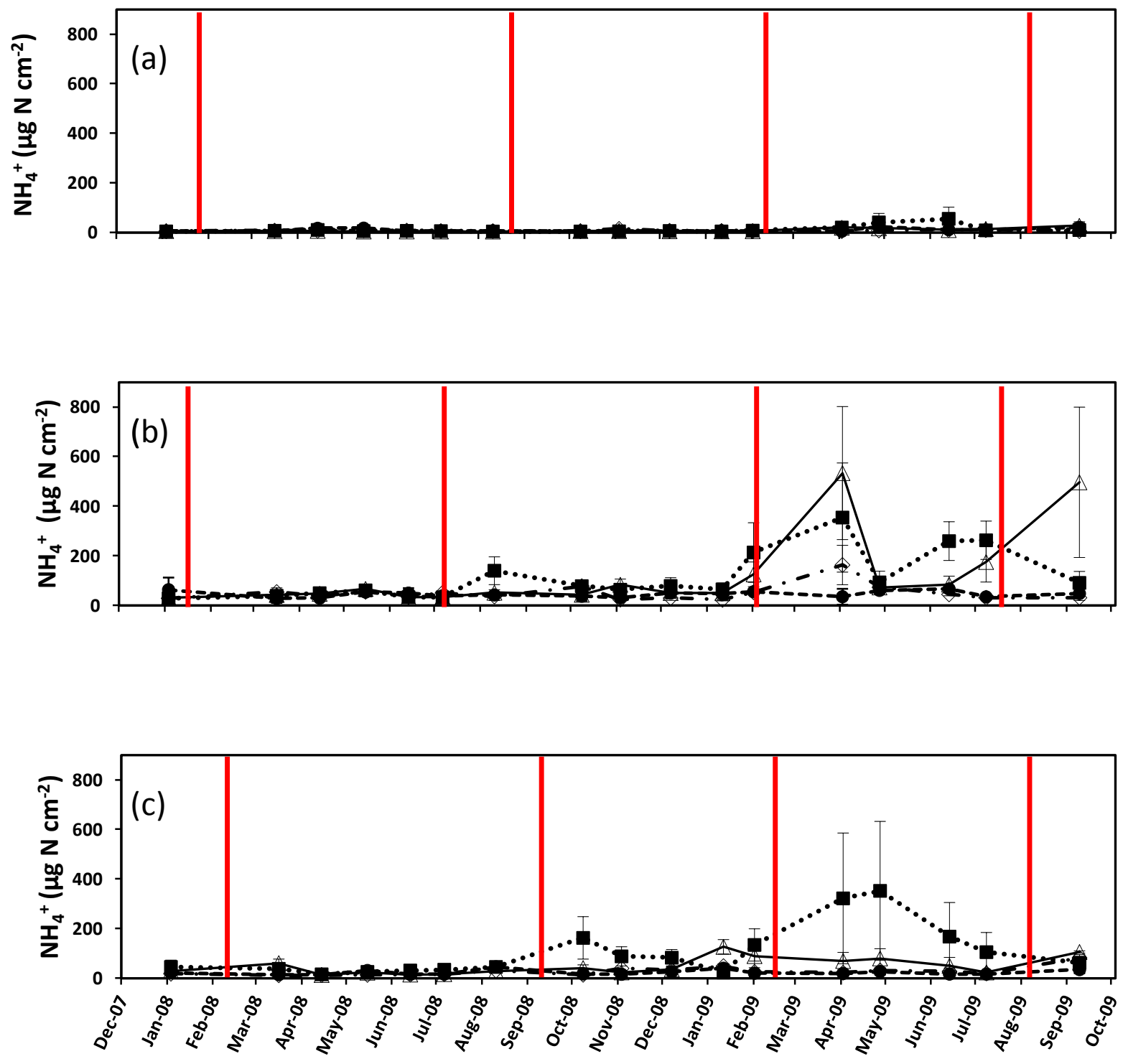

Figure 2. Mean $\left( \pm \mathrm{SE}, n=3\right.$ ) soil extractable $\mathrm{NH}_{4}{ }^{+}$of the top 5-cm soil depth at the (a) 1000-m, (b) 2000-m, and (c) 3000-m sites in the control ( $(0)$, N-addition ( $(\cdot)$, P-addition ( $\bullet$ ) and N+P-addition $(\Delta)$ plots. Red vertical lines indicate nutrient applications. 

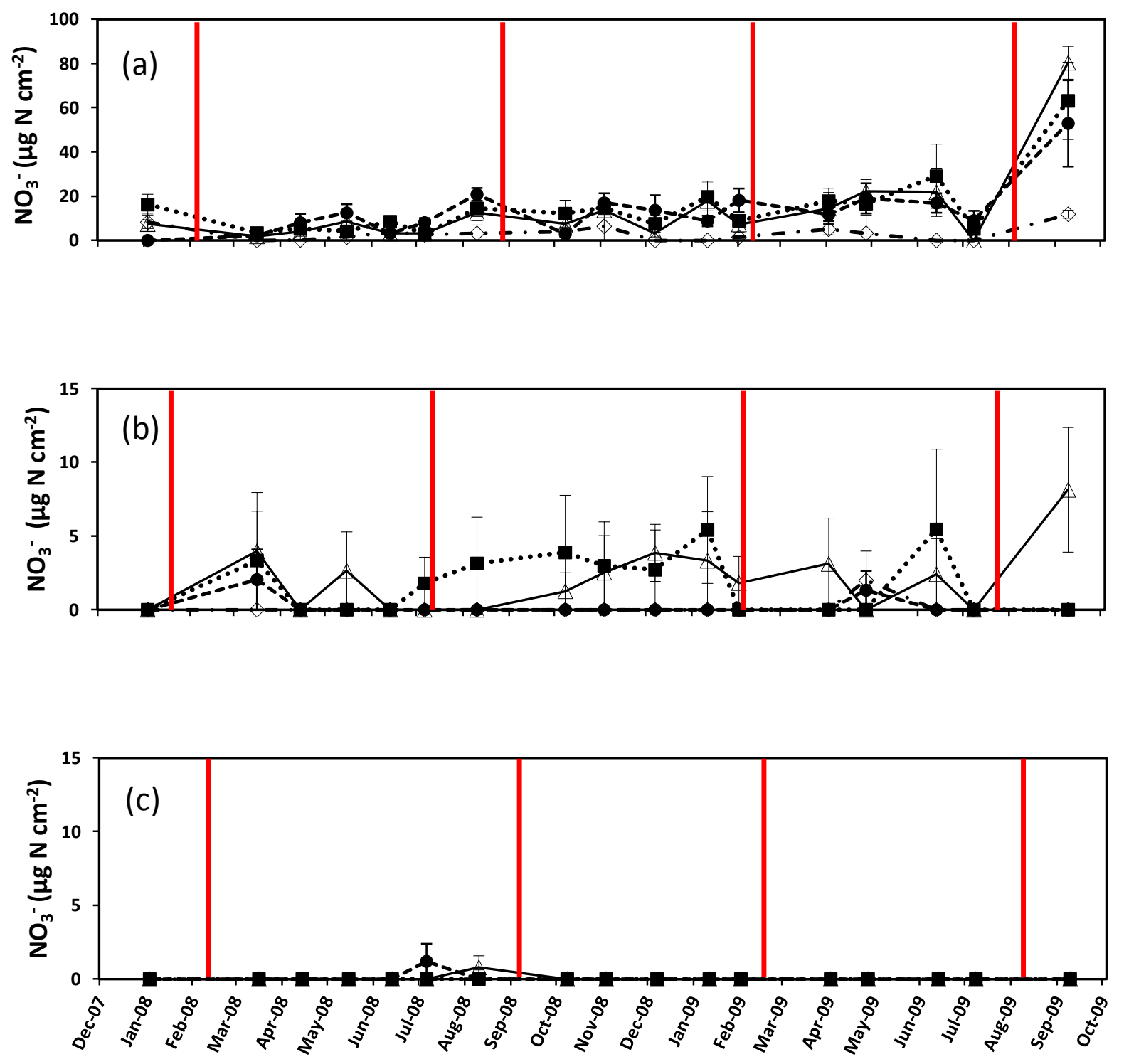

Figure 3. Mean $\left( \pm \mathrm{SE}, n=3\right.$ ) soil extractable $\mathrm{NO}_{3}$ - of the top 5-cm soil depth at the (a) $1000-\mathrm{m}(\mathrm{b})$ 2000-m and (c) 3000-m sites in the control ( $(0), \mathrm{N}$-addition ( $(-), P$-addition $(\bullet)$ and $\mathrm{N}+\mathrm{P}$-addition $(\Delta)$ plots. Red vertical lines indicate nutrient applications.

At each site, net $\mathrm{N}$ mineralization and net nitrification rates of the control plots did not differ between 2008 and 2009. Furthermore, net $\mathrm{N}$ mineralization rates did not differ between elevations and net nitrification rates were only detectable at the $1000-\mathrm{m}$ site (Table 3). Soil $\mathrm{N}_{2} \mathrm{O}$ fluxes were higher at the $1000-\mathrm{m}$ site than at the $2000-\mathrm{m}$ and 3000-m site but did not differ between the 2000-m and 3000-m site. Soil $\mathrm{N}_{2} \mathrm{O}$ fluxes showed no seasonal pattern over the whole study period at any of the elevations (Figure 4 ) and were not correlated with soil mineral N, soil temperature or WFPS. Average $\mathrm{N}_{2} \mathrm{O}$ 
emissions were highest at the 1000 -m site whereas a net annual $\mathrm{N}_{2} \mathrm{O}$ uptake was observed at the 3000-m site showed (Figure 5).

\subsection{Nutrient addition effects on soil mineral $\mathrm{N}$ and net rates of soil N cycling}

At the 1000-m site, following the first and second nutrient addition in 2008, there were no differences in soil mineral $\mathrm{N}$ among treatments. Following the third and fourth nutrient addition in 2009, $\mathrm{NO}_{3}{ }^{-}$contents in the $\mathrm{N}-, \mathrm{P}$ - and $\mathrm{N}+\mathrm{P}$-addition plots were higher compared to the control plots (Figure 3a) but among the nutrient-addition plots $\mathrm{NO}_{3}{ }^{-}$ contents did not differ. Net rates of $\mathrm{N}$ cycling did not differ among treatments in 2008 but net nitrification rates increased in the N+P-addition plots in 2009 (Table 3).

At the 2000-m site, $\mathrm{NH}_{4}{ }^{+}$contents in the $\mathrm{N}$ - and $\mathrm{N}+\mathrm{P}$-addition plots were higher than the control after the third and fourth nutrient addition in 2009 but did not differ between each other (Figure $2 \mathrm{~b}$ ), The $\mathrm{NO}_{3}{ }^{-}$contents increased already after the second nutrient addition in the $\mathrm{N}$ - and $\mathrm{N}+\mathrm{P}$-addition plots but did not differ between each other (Figure 3b). Net rates of $\mathrm{N}$ cycling did not differ among treatments in 2008 and only in 2009 net nitrification rates in $\mathrm{N}$-addition plots were higher than the control but did not differ between $\mathrm{P}$ - and $\mathrm{N}+\mathrm{P}$-addition plots, respectively (Table 3).

At the 3000-m site, $\mathrm{NH}_{4}{ }^{+}$contents started to increase in the $\mathrm{N}$-addition plots after the second $\mathrm{N}$-addition in 2008 (Figure 2c). Neither $\mathrm{NO}_{3}$ - contents nor net $\mathrm{N}$ mineralization rates differed among treatments over the whole sampling period but net nitrification rates became detectable in $\mathrm{N}$ - and $\mathrm{N}+\mathrm{P}$-addition plots in 2009 (Figure 3c and Table 3). 
Table 3. Mean ( $\pm \mathrm{SE}, n=3)$ net rates of soil $\mathrm{N}$ cycling $\left(\mathrm{ng} \mathrm{N} \mathrm{cm}^{-2} \mathrm{~h}^{-1}\right)$ in the forest sites across the elevation gradient, measured in the top 5-cm depth in September 2008 after two nutrient applications and in September 2009 after four nutrient applications.

\begin{tabular}{|c|c|c|c|c|c|c|}
\hline \multirow[t]{2}{*}{ Treatment } & \multicolumn{2}{|c|}{$1000 \mathrm{~m}$ - Bombuscaro } & \multicolumn{2}{|c|}{2000 m - San Francisco } & \multicolumn{2}{|c|}{$3000 \mathrm{~m}$ - Cajanuma } \\
\hline & $\begin{array}{c}\text { Net } \mathrm{N} \\
\text { mineralization }\end{array}$ & Net nitrification & $\begin{array}{c}\text { Net } \mathrm{N} \\
\text { mineralization }\end{array}$ & Net nitrification & $\begin{array}{c}\text { Net } \mathrm{N} \\
\text { mineralization }\end{array}$ & Net nitrification \\
\hline 200 & & & & & & \\
\hline Control & 17.89 (16.67) & 19.47 (15.09) & $23.44(10.48)$ & ND & $1.36(1.44)$ & ND \\
\hline Nitrogen & 36.93 (13.48) & $33.06(15.05)$ & 44.39 (15.3) & $-1.68(1.68)$ & $10.99(6.05)$ & ND \\
\hline Phosphorus & $21.95(7.9)$ & 23.78 (13.18) & $11.17(4.44)$ & ND & $5.58(4.78)$ & ND \\
\hline Nitrogen+Phosphorus & 22.78 (13.57) & 28.06 (12.16) & $40.54 \quad(8.01)$ & $7.79(4.32)$ & $8.41(3.96)$ & ND \\
\hline 200 & & & & & & \\
\hline Control & $8.49(6.0)$ & $3.43(2.74)^{\mathrm{b}}$ & 42.23 (21.11) & $\mathrm{ND}^{\mathrm{b}}$ & 8.07 (3.83) & ND \\
\hline Nitrogen & 34.47 (20.58) & $18.26(14.21)^{\mathrm{ab}}$ & 81.23 (17.23) & $4.06(1.8)^{\mathrm{ab}}$ & 49.65 (44.61) & $2.19(2.19)$ \\
\hline Phosphorus & $74.77(68.45)$ & $18.73(12.98)^{\mathrm{ab}}$ & $28.16(7.92)$ & $2.07(2.07)^{\mathrm{ab}}$ & $8.96(8.44)$ & ND \\
\hline Nitrogen+Phosphorus & $84.7 \quad(57.92)$ & $15.41(7.24)^{\mathrm{a}}$ & $79.72(3.19)$ & $9.38(1.6)^{\mathrm{a}}$ & $8.8(11.21)$ & $1.02(1.02)$ \\
\hline
\end{tabular}

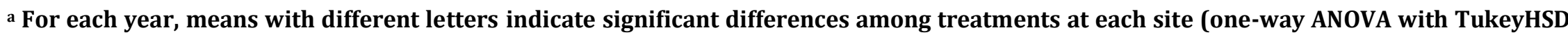
at $P \leq 0.05$ ).

$5 \mathrm{ND}$ - non detectable $\mathrm{NO}_{3}$ - concentrations of soil extracts were below the detection limit of $0.10 \mathrm{mg} \mathrm{NO}_{3}^{--} \mathrm{N} \mathrm{L}^{-1}$ ) 


\subsection{Nutrient addition effects on soil $\mathrm{N}_{2} \mathrm{O}$ fluxes}

At the $1000-\mathrm{m}$ site, $\mathrm{N}_{2} \mathrm{O}$ emissions started to increase following first nutrient additions in 2008 (Figure 4a) and were larger in the N-and N+P-addition plots compared to the control plots after the second nutrient addition in 2008 and after the fourth nutrient addition in 2009 (Figure 5). Between $\mathrm{N}$ - and $\mathrm{N}+\mathrm{P}$-addition plots, $\mathrm{N}_{2} \mathrm{O}$ emissions did not differ. The relative increase of average soil $\mathrm{N}_{2} \mathrm{O}$ emissions in 2009 compared to the control was a factor 3 and 4 in the $\mathrm{N}$ - and $\mathrm{N}+\mathrm{P}$-addition plots, respectively (Figure $5 \mathrm{~b}$ ).

At the 2000-m site, $\mathrm{N}_{2} \mathrm{O}$ fluxes did not differ among treatments after the second nutrient addition in 2008 (Figure 5a), but started to increase in 2009 and were larger in the $\mathrm{N}$ - and $\mathrm{N}+\mathrm{P}$-addition plots compared to the control plots after the fourth nutrient addition. The relative increase of average soil $\mathrm{N}_{2} \mathrm{O}$ emissions in 2009 compared to the control was a factor 11 and 15 in the $\mathrm{N}$ - and $\mathrm{N}+\mathrm{P}$-addition plots, respectively (Figure $5 b)$.

Also at the 3000-m site, $\mathrm{N}_{2} \mathrm{O}$ fluxes did not differ among treatments in 2008 but started to increase in 2009 and were larger in the $\mathrm{N}$ - and $\mathrm{N}+\mathrm{P}$-addition plots compared to the control plots after the fourth nutrient addition (Figure 4c). Additionally, average soil $\mathrm{N}_{2} \mathrm{O}$ fluxes turned from a net uptake in the control plots into a net source in the $\mathrm{N}$ and $\mathrm{N}+\mathrm{P}$-addition plots in 2009 (Figure 5b). 

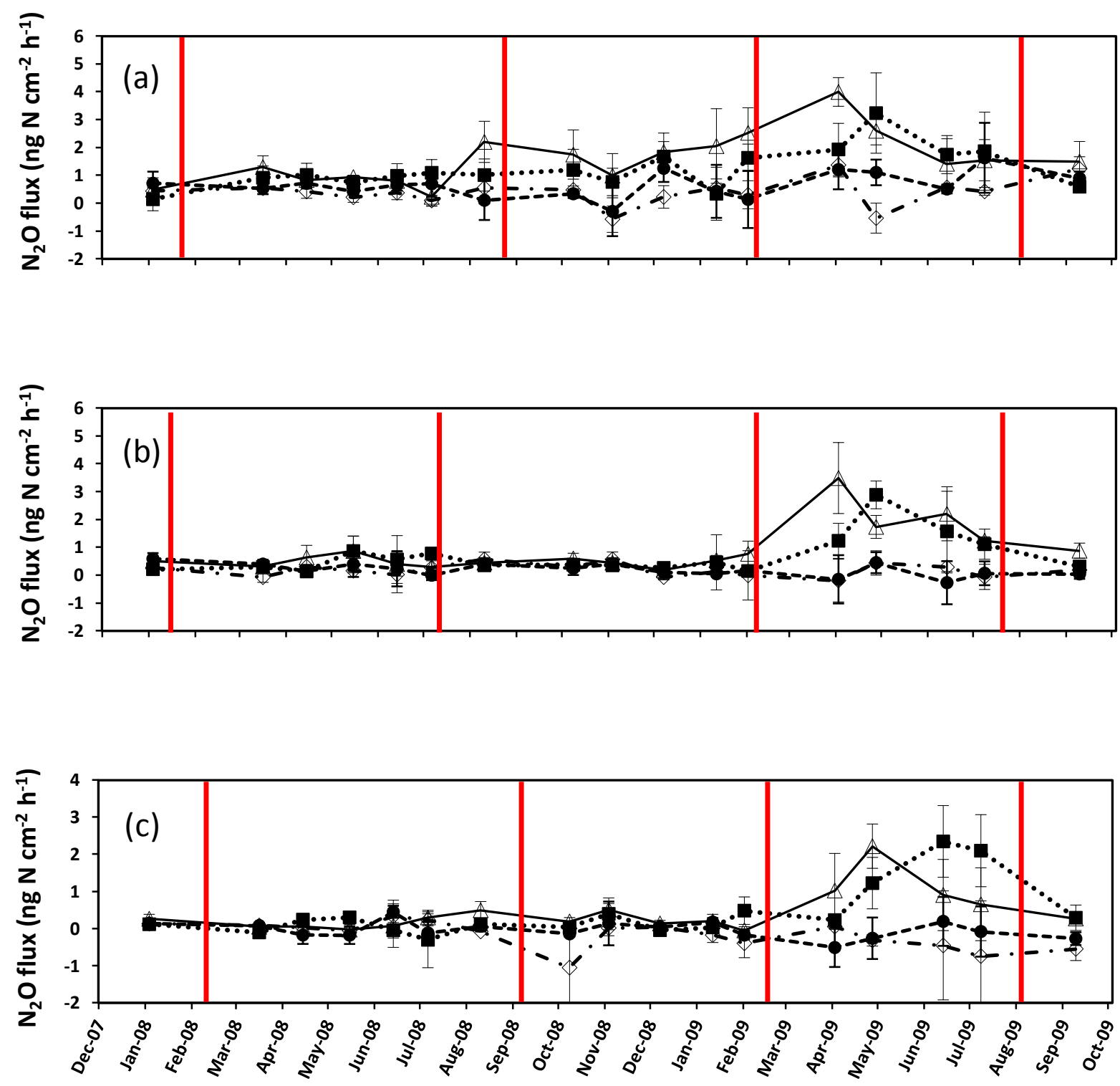

Figure 4. Mean ( $\pm \mathrm{SE}, n=3$ ) $\mathrm{N}_{2} \mathrm{O}$ fluxes at the (a) 1000-m, (b) 2000-m, and (c) 3000-m sites in the control $(\diamond), \mathrm{N}$-addition $(\boldsymbol{(}), \mathrm{P}$-addition $(\bullet)$ and $\mathrm{N}+\mathrm{P}$-addition $(\Delta)$ plots. Red vertical lines indicate nutrient applications. 

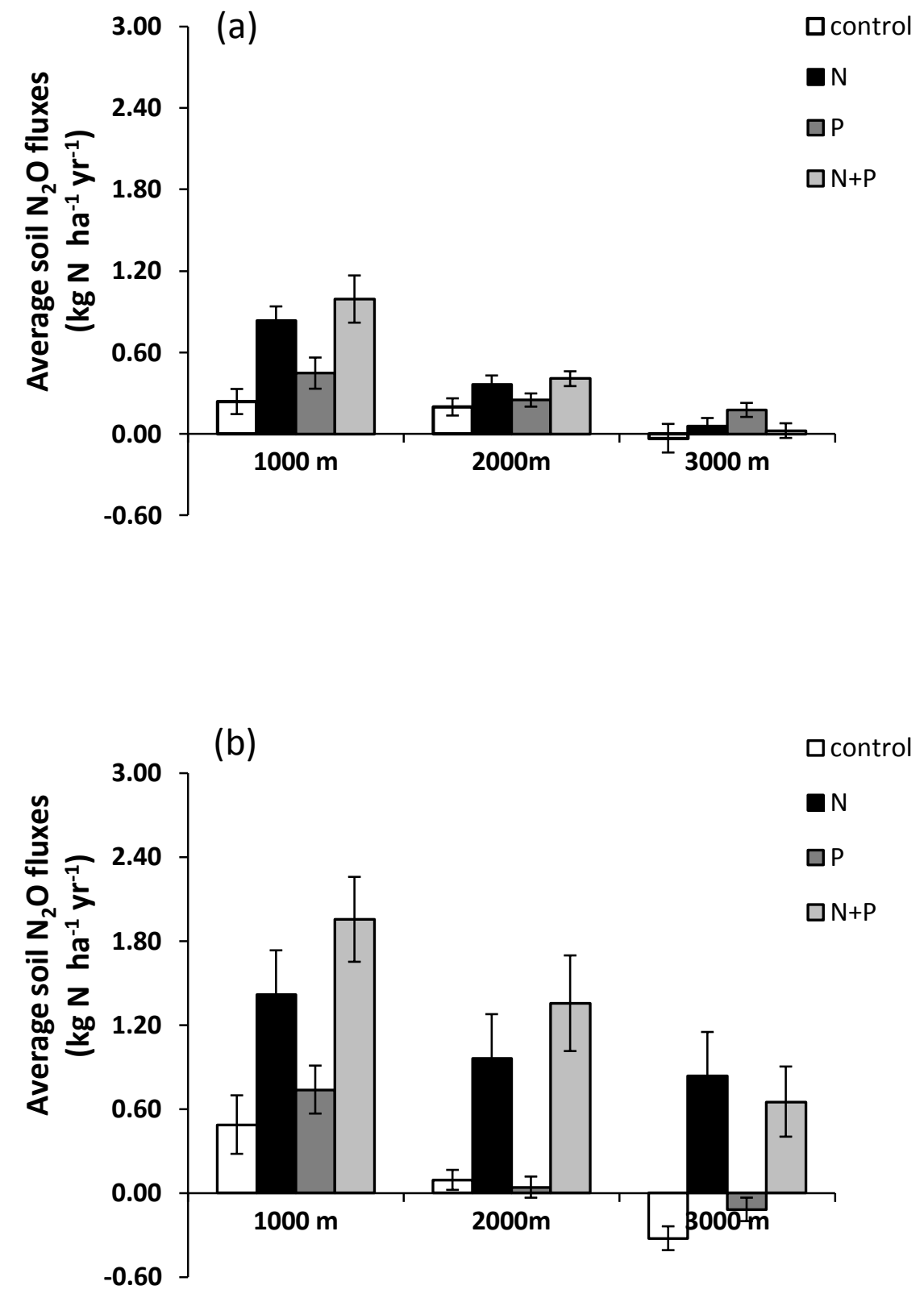

Figure 5. Average soil $\mathrm{N}_{2} \mathrm{O}$ fluxes $\left(\mathrm{kg} \mathrm{N}^{\mathrm{N}} \mathrm{ha}^{-1} \mathrm{yr}^{-1}\right.$, mean $\pm \mathrm{SE}, n=3$ with 10 and 7 monthly measurements for 2008 and for 2009) in the control, $\mathrm{N}$-addition, $\mathrm{P}$-addition and $\mathrm{N}+\mathrm{P}$-addition plots of the forest sites across the elevation gradient in 2008 (a) and 2009 (b). 


\section{DISCUSSION}

\subsection{Soil $\mathrm{N}$ cycle and $\mathrm{N}_{2} \mathrm{O}$ fluxes from control plots}

Although the amount of extractable inorganic $\mathrm{N}$ in the organic layer was higher at the 2000-m and 3000-m site than in the mineral soil at the 1000-m site (Figure 2,3), net rates of $\mathrm{N}$ cycling almost showed the reverse pattern (Table 3). Similar patterns were already observed in other studies (Arnold et al. 2009, Koehler et al. 2009, Marrs et al. 1988, Silver et al. 1994). At the 2000-m and 3000-m sites the mineralized N was immobilized, while at the $1000-\mathrm{m}$ site where no organic layer existed most of the mineralized $\mathrm{N}$ was nitrified in the mineral soil (Table 3). The lack of nitrification in the organic layer at the two higher elevation sites was probably caused by increasing $\mathrm{N}$ competition at higher elevations (Arnold et al. 2009). Hence, these results suggest that $\mathrm{N}$ availability decreased with increasing elevation which corresponded to the sites with thick organic layers. Low $\mathrm{N}$ availability at these sites is probably caused by incomplete decomposition of litter and buildup of organic matter which is related to low soil temperature and consequently reduced enzyme activity (Grubb 1977). In addition, the feedback of tree vegetation to the environmental conditions in combination with the low nutrient availability probably reduced litter quality and consequently contributed to the increased organic layer thickness with increasing elevation (Wolf et al., unpublished results).

Since soil N oxide emissions are primarily controlled by N availability (Davidson et al. 2000), average soil $\mathrm{N}_{2} \mathrm{O}$ emissions decreased with elevation as well (Figure 5). However, their overall level was much lower than reported by other studies from tropical montane forest soils (Breuer et al. 2000, Holtgrieve et al. 2006, Koehler et al. 2009, Purbopuspito et al. 2006, Riley \& Vitousek 1995). Low N availability in combination with strong competition for $\mathrm{N}$ should lead to higher $\mathrm{N}$-retention and efficient recycling of available $\mathrm{N}$ (Perakis et al. 2005). To evaluate the efficiency of the forest in using available $\mathrm{N}$ at each elevation, we calculated the $\mathrm{N}_{2} \mathrm{O}$ losses in relation to 
soil $\mathrm{N}$ availability. The ratio of average soil $\mathrm{N}_{2} \mathrm{O}$ emissions to the net $\mathrm{N}$ mineralization decreased with increasing elevation and was $\sim 1.5 \%$ of the net $\mathrm{N}$ mineralization rates in the top $5 \mathrm{~cm}$ of the soil at the 1000-m site and $\sim 1 \%$ at the $2000-\mathrm{m}$ site (Table 3, 4). At the 3000-m site average $\mathrm{N}_{2} \mathrm{O}$ emissions were not different from zero which leads to a ratio that was also zero (Figure 5). The high soil $\mathrm{N}$ retention efficiency and the low soil $\mathrm{N}$ availability at the 2000-m and 3000-m site are typical for a "conservative" soil N cycle, where biological $\mathrm{N}$ demand exceeds $\mathrm{N}$ supply (Koehler et al. 2009). Although $\mathrm{N}$ availability tended to be higher at the 1000-m site, (as shown by measurable nitrification rates), the $\mathrm{N}$ retention efficiency tended to decrease only little. Unlike tropical lowland forests, where $\mathrm{N}$ supply exceeds biological $\mathrm{N}$ demand leading to higher $\mathrm{N}_{2} \mathrm{O}$ losses, the higher $\mathrm{N}$ availability at the $1000-\mathrm{m}$ site was insufficient to meet biological $\mathrm{N}$ demand in the control plots.

\subsection{Nutrient controls of soil $\mathrm{N}$ cycle and $\mathrm{N}_{2} \mathrm{O}$ fluxes at $1000 \mathrm{~m}$ elevation}

Stem diameter growth did not respond to $\mathrm{N}$ or $\mathrm{P}$ addition at the $1000-\mathrm{m}$ site after the first year of nutrient manipulation (J. Homeier, unpublished results). The small changes in soil $\mathrm{N}$ cycling rates following $\mathrm{N}$ addition (Figure $2 \mathrm{a}, 3 \mathrm{a}$ ) were more consistent with a relatively "conservative" soil N cycle than with a soil N cycle where N supply exceeds biological $\mathrm{N}$ demand with large changes in soil $\mathrm{N}$ cycling rates following $\mathrm{N}$ additions (Koehler et al. 2009). After the first and second $\mathrm{N}$ addition in 2008, $\mathrm{N}_{2} \mathrm{O}$ emissions increased gradually (Figure $4 \mathrm{a}$ ) and were $\sim 2.6 \%$ of the net mineralization rates in the Naddition plots and $\sim 5.0 \%$ in the $\mathrm{N}+\mathrm{P}$-addition plots (Table 3, Figure 5a), which was probably induced by an increase in $\mathrm{N}$ availability. The gradual increase in $\mathrm{N}_{2} \mathrm{O}$ emissions were comparable to soil $\mathrm{N}_{2} \mathrm{O}$ emissions in a P limited tropical montane forest at $\sim 1000$ m elevation in Hawaii (Hall \& Matson 2003). However in this forest the amount of $\mathrm{N}$ applied was twice as much and the initial soil $\mathrm{N}$ availability was much higher than at our site. This apparent inconsistency may be explained by the different soil WFPS. In our 
study at the 1000-m site, WFPS ranged between 60 and $80 \%$ (Figure $1 \mathrm{~b}$ ) which favours denitrification over nitrification. In contrast, the soil WFPS at the Hawaiian site was on average $47 \%$, which is far below the optimum range for nitrification and denitrification (Bollmann \& Conrad 1998, Stark \& Firestone 1995, Tiedje \& Zehnder 1988). Hence, conditions for nitrifying and denitrifying bacteria were more favorable at our site compared to the Hawaiian site. This may also explain the more sensitive reaction to $\mathrm{N}$ additions that we observed.

The lack of reaction of soil $\mathrm{N}_{2} \mathrm{O}$ emissions and $\mathrm{N}$ cycling rates to $\mathrm{P}$ additions suggests that $\mathrm{P}$ addition did not affect soil $\mathrm{N}$ availability. This may be explained by a $\mathrm{P}$ uptake of the vegetation at the 1000-m site. Stem diameter growth did not respond to N or $\mathrm{P}$ addition at the $1000-\mathrm{m}$ site after the first year of nutrient additions (J. Homeier, unpublished results) but it remains to be seen whether the amount of added P has so far been insufficient to induce changes in vegetation growth and consecutive P-additions will lead to significant responses. A closer scrutiny of our data provides some indirect evidence for a stimulating effect of $\mathrm{P}$ on soil $\mathrm{N}$ cycling processes at the $1000-\mathrm{m}$ site. While net nitrification did not increase significantly after $\mathrm{N}$ addition alone, it did increase after combined $\mathrm{N}+\mathrm{P}$ addition in 2009 (Table 3). Furthermore, $\mathrm{N}_{2} \mathrm{O}$ emissions showed the tendency to be higher after $\mathrm{N}+\mathrm{P}$ addition than after $\mathrm{N}$ addition, alone (Figure $4 a, 5 b)$. Hence, the lack of significant effects at the 1000-m site in the early stage of this experiment may be due to the low amount of added $\mathrm{P}$, which was probably insufficient to overcome the biological $\mathrm{P}$ demand and/or to overcome any $\mathrm{P}$ limitation in the decomposition process. $\mathrm{P}$ can limit different steps in the sequential breakdown of leaf litter and even the whole leaf litter decomposition (Kaspari et al. 2008), which in turn increases soil $\mathrm{N}$ availability. Whether rates of soil $\mathrm{N}$ cycling and $\mathrm{N}_{2} \mathrm{O}$ losses will progressively increase in the P-addition plots or whether the nutrient limitation of the vegetation will change and affect soil $\mathrm{N}$ cycling processes remain to be seen (Davidson \& Howarth 2007, Elser et al. 2007). 


\subsection{Nutrient controls of soil $\mathrm{N}$ cycle and $\mathrm{N}_{2} \mathrm{O}$ fluxes at 2000 and 3000 m elevation}

The small changes in soil $\mathrm{N}$ cycling rates following $\mathrm{N}$ and $\mathrm{N}+\mathrm{P}$ addition at the $2000-\mathrm{m}$ and 3000-m site (Table 3) are consistent with a relatively "conservative" soil N cycle (Koehler et al. 2009). However, soil $\mathrm{N}_{2} \mathrm{O}$ emissions gradually increased in the $\mathrm{N}$ - and $\mathrm{N}+\mathrm{P}$-addition plots in 2009 (Figure $4 \mathrm{~b}, \mathrm{c}$ ) and were $\sim 0.5 \%$ of the net mineralization rates in the $\mathrm{N}$ - and $\sim 0.6 \%$ in the $\mathrm{N}+\mathrm{P}$-addition plots at the 2000 -m site and $\sim 0.1 \%$ and $2.3 \%$, respectively, at the 3000-m site (Table 3, Figure 5b). This was likely induced by a priming effect (Fontaine et al. 2004), causing an increase in $\mathrm{N}$ availability in the organic layer. Net nitrification rates increased after N+P at the 2000-m site and also tended to increase at the $3000-\mathrm{m}$ site (Table 3). The effects of $\mathrm{N}$ and $\mathrm{N}+\mathrm{P}$ addition on rates of soil $\mathrm{N}$ cycling at the 3000-m site were not yet significant, probably because at higher elevations soil $\mathrm{N}$ cycling processes are constrained by the low temperature that inhibits microbial activity. At both elevations, the moderate amount of added $\mathrm{N}$ may have been sufficient to satisfy biological $\mathrm{N}$ demand which resulted in extra available $\mathrm{N}$ to stimulate mineralization and nitrification rates in the organic layer. This is in contrast with measurements in an $\mathrm{N}$ limited Hawaiian tropical montane forest soil without organic layer, where a larger $\mathrm{N}$ addition (175 $\mathrm{kg} \mathrm{N} \mathrm{ha}^{-1} \mathrm{yr}^{-1}$ ) did not cause any increase in $\mathrm{N}_{2} \mathrm{O}$ emissions (Hall \& Matson 1999, Hall \& Matson 2003). Our results are more in line with findings in Panama where average $\mathrm{N}_{2} \mathrm{O}$ emissions doubled after $\mathrm{N}$ addition $(125 \mathrm{~kg} \mathrm{~N}$ ha${ }^{1} \mathrm{yr}^{-1}$ ) in an $\mathrm{N}$ limited Panamanian tropical montane forest soil with an organic layer (Koehler et al. 2009). We explain the observed differences in $\mathrm{N}$-addition effects on soil $\mathrm{N}$ cycling and $\mathrm{N}_{2} \mathrm{O}$ emissions by the presence or absence of an organic layer, where rates of soil $\mathrm{N}$ cycling increase substantially with $\mathrm{N}$ addition independent from nutrient limitation of vegetation growth (Fontaine et al. 2004, Koehler et al. 2009).

Since P addition had no effect on soil N cycling at the 2000-m and 3000-m site, the effects of $\mathrm{N}+\mathrm{P}$ addition on the soil $\mathrm{N}$ cycle which were not different from the $\mathrm{N}$ addition, were probably caused by the $\mathrm{N}$ alone. The amount of $\mathrm{P}$ added in our nutrient manipulation experiment may have been insufficient to overcome any potential $\mathrm{P}$ 
limitation to the decomposition process. If this is the case we may expect effects on $\mathrm{N}$ cycling change after further P additions. However, if the low soil WFPS in the organic layer (Figure 1) minimizes denitrifier activity, further $\mathrm{P}$ additions may not lead to changes in the N cycle (Liu \& Song 2010).

\subsection{Soil nutrient status of tropical montane forests and its implications for increasing Nitrogen deposition}

The results of the first two years of our experiment showed that the magnitude and timing of changes in rates of soil $\mathrm{N}$ cycling and $\mathrm{N}_{2} \mathrm{O}$ emissions in tropical montane forests following nutrient addition depend primarily on the interplay between the soil $\mathrm{N}$ status and the amount of nutrient added. The soil $\mathrm{N}$ status was independent from nutrient demand by the vegetation and appeared to be controlled by the presence or absence of an organic layer and possibly by soil hydrological properties (e.g. WFPS). Ultimately this is controlled by low temperatures at higher elevations which may inhibit microbial activity in decomposition but feedback mechanisms of vegetation to harsher conditions may also have played a role. The diversity of soils is much higher in tropical mountain forests than in tropical lowland forests (Richter \& Babbar 1991). These different soil types are associated with differing status of the soil $\mathrm{N}$ cycle in tropical montane forests (Wolf et al., unpublished results) which makes it difficult to predict the impact of future climate changes on soil $\mathrm{N}$ cycling and soil $\mathrm{N}_{2} \mathrm{O}$ emissions in tropical montane forests. The rapid short-term impacts on rates of soil $\mathrm{N}$ cycling and soil $\mathrm{N}_{2} \mathrm{O}$ emissions in tropical montane forest soils even by moderate $\mathrm{N}$ additions, suggests that tropical montane forests are strongly susceptible to increased nitrogen deposition in the future. 


\section{REFERENCES}

Adamek, M., M. D. Corre, and D. Holscher. 2009. Early effect of elevated nitrogen input on above-ground net primary production of a lower montane rain forest, Panama. Journal of Tropical Ecology 25:637-647.

Arnold, J., M. D. Corre, and E. Veldkamp. 2009. Soil N cycling in old-growth forests across an Andosol toposequence in Ecuador. Forest Ecology and Management 257:2079-2087.

Bollmann, A., and R. Conrad. 1998. Influence of $\mathrm{O}_{2}$ availability on $\mathrm{NO}$ and $\mathrm{N}_{2} \mathrm{O}$ release by nitrification and denitrification in soils. Global Change Biology 4:387-396.

Breuer, L., R. Kiese, and K. Butterbach-Bahl. 2002. Temperature and moisture effects on nitrification rates in tropical rain-forest soils. Soil Science Society of America Journal 66:834-844.

Breuer, L., H. Papen, and K. Butterbach-Bahl. 2000. N20 emission from tropical forest soils of Australia. Journal of Geophysical Research-Atmospheres 105:2635326367.

Burghouts, T. B. A., N. M. Van Straalen, and L. A. Bruijnzeel. 1998. Spatial heterogeneity of element and litter turnover in a Bornean rain forest. Journal of Tropical Ecology 14:477-505.

Corre, M. D., E. Veldkamp, J. Arnold, and S. J. Wright. 2010. Impact of elevated N input on soil $\mathrm{N}$ cycling and losses in old-growth lowland and montane forests in Panama. Ecology 91:1715-1729.

Crawley M. J. 2010. The R book. John Wiley \& Sons Ltd, Chinchester, West Sussex. 
Davidson, E. A., and R. W. Howarth. 2007. Environmental science - nutrients in synergy. Nature 449:1000-1001.

Davidson, E. A., M. Keller, H. E. Erickson, L. V. Verchot, and E. Veldkamp. 2000. Testing a conceptual model of soil emissions of nitrous and nitric oxides. Bioscience 50:667-680.

Elser, J. J., M. E. S. Bracken, E. E. Cleland, D. S. Gruner, W. S. Harpole, H. Hillebrand, J. T. Ngai, E. W. Seabloom, J. B. Shurin, and J. E. Smith. 2007. Global analysis of nitrogen and phosphorus limitation of primary producers in freshwater, marine and terrestrial ecosystems. Ecology Letters 10:1135-1142.

Emck P. 2008. A climatology of south Ecuador: with special focus on the major Andean climate divide. Vdm Verlag.

Fabian, P., M. Kohlpaintner, and R. Rollenbeck. 2005. Biomass burning in the Amazonfertilizer for the mountaineous rain forest in Ecuador. Environmental Science and Pollution Research 12:290-296.

Falkiner, R. A., P. K. Khanna, and R. J. Raison. 1993. Effect of superphosphate addition on $\mathrm{N}$-mineralization in some Australian forest soils. Australian Journal of Soil Research 31:285-296.

Field, C. B., M. J. Behrenfeld, J. T. Randerson, and P. Falkowski. 1998. Primary production of the biosphere: Integrating terrestrial and oceanic components. Science 281:237-240.

Fontaine, S., G. Bardoux, L. Abbadie, and A. Mariotti. 2004. Carbon input to soil may decrease soil carbon content. Ecology Letters 7:314-320.

Grubb, P. J. 1977. Control of forest growth and distribution on wet tropical mountains with special reference to mineral-nutrition. Annual Review of Ecology and Systematics 8:83-107. 
Hall, S. J., and P. A. Matson. 1999. Nitrogen oxide emissions after nitrogen additions in tropical forests. Nature 400:152-155.

Hall, S. J., and P. A. Matson. 2003. Nutrient status of tropical rain forests influences soil N dynamics after N additions. Ecological Monographs 73:107-129.

Hart, S. C. 2010. Nitrogen mineralisation, immobilisation and nitrification. Pages 985 1018 in R. W. Weaver editor. Methods of Soil Analysis, Part 2: Microbial and Biochemical Properties. Madison, USA.

Hobbie, S. E., and P. M. Vitousek. 2000. Nutrient limitation of decomposition in Hawaiian forests. Ecology 81:1867-1877.

Holtgrieve, G. W., P. K. Jewett, and P. A. Matson. 2006. Variations in soil N cycling and trace gas emissions in wet tropical forests. Oecologia 146:584-594.

Homeier, J., S. W. Breckle, S. Gunter, R. T. Rollenbeck, and C. Leuschner. 2010. Tree diversity, forest structure and productivity along altitudinal and topographical gradients in a species-rich Ecuadorian montane rain forest. Biotropica 42:140148.

Homeier, J., F. A. Werner, S. R. Gradstein, S. W. Breckle, and M. Richter. 2008. Potential vegetation and floristic composition of Andean forests in south Ecuador, with a focus on the RBSF. in E. Beck, J. Bendix, I. Kottke, F. Makeschin, and R. Mosandl editors. Ecological Studies: Gradients in a Tropical Mountain Ecosystem of Ecuador. Springer Verlag, Berlin Heidelberg.

IPCC. Climate Change 2007: The Physical Science Basis. Contribution of Working Group I to the Fourth Assessment Report of the Intergovernmental Panel on Climate Change. Solomon, S., Manning, M., Chen, Z., Marquis, M., Averyt, K. B., Tignor, M., and Miller, H. L. 2007. Cambridge University Press, Cambridge, United Kingdom and New York, USA. 
IUSS Working Group WRB. 2006. World reference base for soil resources., 2nd edition. FAO, Rome.

Kaspari, M., M. N. Garcia, K. E. Harms, M. Santana, S. J. Wright, and J. B. Yavitt. 2008. Multiple nutrients limit litterfall and decomposition in a tropical forest. Ecology Letters 11:35-43.

Keller, M., W. A. Kaplan, S. C. Wofsy, and J. M. DaCosta. 1988. Emissions of $\mathrm{N}_{2} \mathrm{O}$ from tropical forest soils: response to fertilization with $\mathrm{NH}_{4}{ }^{+}, \mathrm{NO}_{3}{ }^{-}$, and $\mathrm{PO}_{4}$. Journal of Geophysical Research-Oceans 93:1600-1604.

Koehler, B., M. D. Corre, E. Veldkamp, H. Wullaert, and S. J. Wright. 2009. Immediate and long-term nitrogen oxide emissions from tropical forest soils exposed to elevated nitrogen input. Global Change Biology 15:2049-2066.

Liu, D. Y., and C. C. Song. 2010. Effects of inorganic nitrogen and phosphorus enrichment on the emission of $\mathrm{N}_{2} \mathrm{O}$ from a freshwater marsh soil in Northeast China. Environmental Earth Sciences 60:799-807.

Loftfield, N., H. Flessa, J. Augustin, and F. Beese. 1997. Automated gas chromatographic system for rapid analysis of the atmospheric trace gases methane, carbon dioxide, and nitrous oxide. Journal of Environmental Quality 26:560-564.

Malhi, Y., and O. L. Phillips. 2004. Tropical forests and global atmospheric change: a synthesis. Philosophical Transactions of the Royal Society of London Series BBiological Sciences 359:549-555.

Marrs, R. H., J. Proctor, A. Heaney, and M. D. Mountford. 1988. Changes in soil nitrogenmineralization and nitrification along an altitudinal transect in tropical rainforest in Costa-Rica. Journal of Ecology 76:466-482.

Moser, G., D. Hertel, and C. Leuschner. 2007. Altitudinal change in LAI and stand leaf biomass in tropical montane forests: a transect shady in Ecuador and a pantropical meta-analysis. Ecosystems 10:924-935. 
Perakis, S. S., J. E. Compton, and L. O. Hedin. 2005. Nitrogen retention across a gradient of N-15 additions to an unpolluted temperate forest soil in Chile. Ecology 86:96105.

Purbopuspito, J., E. Veldkamp, R. Brumme, and D. Murdiyarso. 2006. Trace gas fluxes and nitrogen cycling along an elevation sequence of tropical montane forests in Central Sulawesi, Indonesia. Global Biogeochemical Cycles 20.

Richter, D. D., and L. I. Babbar. 1991. Soil diversity in the tropics. Advances in Ecological Research 21:315-389.

Riley, R. H., and P. M. Vitousek. 1995. Nutrient dynamics and nitrogen trace gas flux during ecosystem development in montane rain-forest. Ecology 76:292-304.

Silver, W. L., F. N. Scatena, A. H. Johnson, T. G. Siccama, and M. J. Sanchez. 1994. Nutrient availability in a montane wet tropical forest - spatial patterns and methodological considerations. Plant and Soil 164:129-145.

Stark, J. M., and M. K. Firestone. 1995. Isotopic labeling of soil nitrate pools using nitrogen-15-nitric oxide gas. Soil Science Society of America Journal 59:844-847.

Sterner R. W., and J. J. Elser. 2002. Ecological stoichiometry: the biology of elements from molecules to the biosphere. Princeton University Press, Princeton, NJ, USA.

Tanner, E. V. J., V. Kapos, and W. Franco. 1992. Nitrogen and phosphorus fertilization effects on Venezuelan montane forest trunk growth and litterfall. Ecology 73:7886.

Tanner, E. V. J., V. Kapos, S. Freskos, J. R. Healey, and A. M. Theobald. 1990. Nitrogen and phosphorus fertilization of Jamaican montane forest trees. Journal of Tropical Ecology 6:231-238.

Tanner, E. V. J., P. M. Vitousek, and E. Cuevas. 1998. Experimental investigation of nutrient limitation of forest growth on wet tropical mountains. Ecology 79:10-22. 
Tiedje, J. M., and A. J. B. Zehnder. 1988. Ecology of denitrification and dissimilatory nitrate reduction to ammonia. Pages 179-244 in Biology of Anaerobic Microorganisms. Wiley, Chichester.

Trumbore, S. 2009. Radiocarbon and soil carbon dynamics. Annual Review of Earth and Planetary Sciences 37:47-66.

Vitousek, P. M., L. R. Walker, L. D. Whiteaker, and P. A. Matson. 1993. Nutrient limitations to plant-growth during primary succession in hawaii-volcanos-national-park. Biogeochemistry 23:197-215.

Walker, T. W., and J. K. Syers. 1976. Fate of phosphorus during pedogenesis. Geoderma 15:1-19.

White, J. R., and K. R. Reddy. 2003. Nitrification and denitrification rates of everglades wetland soils along a phosphorus-impacted gradient. Journal of Environmental Quality 32:2436-2443.

Wilcke, W., S. Yasin, U. Abramowski, C. Valarezo, and W. Zech. 2002. Nutrient storage and turnover in organic layers under tropical montane rain forest in Ecuador. European Journal of Soil Science 53:15-27. 


\title{
CHAPTER IV
}

\section{RESPONSE OF SOIL RESPIRATION TO NutRIENT ADDITIONS IN MONTANE FORESTS ALONG AN ELEVATION GRADIENT IN SOUTHERN ECUADOR}

\author{
Guntars Martinson¹, Edzo Veldkamp ${ }^{1}$
}

${ }^{1}$ Büsgen Institute - Soil Science of Tropical and Subtropical Ecosystems, Georg-AugustUniversity of Goettingen, Buesgenweg 2, 37077 Goettingen, Germany 


\section{ABSTRACT}

Soil respiration in tropical forests is one of the largest and least understood C fluxes in terrestrial ecosystems. In contrast to soil temperature and moisture, nutrient controls on soil respiration have rarely been studied in tropical forests and most studies are heavily biased towards tropical lowland forests. We established a nutrient-addition experiment (nitrogen $(N)$, phosphorus $(P), N+P$, and control) to achieve nutrient-enriched conditions across an elevation gradient. Fertilizers were applied at the rates of $50 \mathrm{~kg} \mathrm{~N} \mathrm{ha}^{-1} \mathrm{yr}^{-1}$ (in the form of urea) and $10 \mathrm{~kg} \mathrm{P} \mathrm{ha-1} \mathrm{yr}^{-1}$ (in the form of $\mathrm{NaH}_{2} \mathrm{PO}_{4} \cdot 2 \mathrm{H}_{2} \mathrm{O}$ with analytical grade quality) split in two equal applications. Our objective was to assess changes in soil respiration and total litterfall under elevated $N$ and $P$ conditions in an old-growth premontane rain forest at $1000-\mathrm{m}$, an old-growth lower montane rain forest at 2000-m and an old-growth upper montane rainforest at 3000-m elevation.

At 1000-m elevation, where vegetation growth did not respond to $N$ and $P$ addition, nutrient additions had no effect on soil respiration. At 2000-m elevation, where vegetation growth did not respond to nutrient additions, soil respiration increased in the $\mathrm{N}$-addition plots in 2009. At 3000-m elevation, where vegetation growth likewise did not respond to nutrient additions, soil respiration increased already in 2008 in the $\mathrm{N}$-addition plots. The increase in soil respiration may be caused by a stimulation of heterotrophic respiration in the soil organic layer at the two higher elevation sites. Soil $\mathrm{C}$ dynamics in tropical montane forests responded to moderate $\mathrm{N}$ additions independent from nutrient demand of vegetation. Our results suggest that projected increases in tropical $\mathbf{N}$ deposition may enhance rates of soil respiration in tropical montane forests. 


\section{INTRODUCTION}

Nitrogen (N) and Phosphorus (P) are nutrients that frequently limit ecosystem processes (Elser et al. 2007, Vitousek et al. 2010). They limit plant productivity and determine carbon (C) allocation (Bown et al. 2009, Vitousek et al. 2010) and soil $\mathrm{CO}_{2}$ efflux (soil respiration) (Finzi et al. 2011, Magnani et al. 2007). Soil respiration is the second largest but also one of the least understood C flux in terrestrial ecosystems (Giardina et al. 2005, Litton \& Giardina 2008) although even small changes in soil respiration induced by climate change can have significant impacts on atmospheric $\mathrm{CO}_{2}$ concentration (Schlesinger \& Andrews 2000). Soil respiration consists of root respiration (autotrophic respiration) and microbial respiration (heterotrophic respiration) and both fluxes are primarily controlled by soil temperature, soil moisture and nutrient availability (Davidson et al. 2000, Koehler et al. 2009). Several studies suggest that nutrient limitation to decomposition differs from nutrient limitation to net primary productivity (NPP). Hence, nutrient controls on heterotrophic and autotrophic respiration may differ as well. Nutrient controls on soil respiration have rarely been studied in tropical forest ecosystems (Janssens et al. 2010) and the few studies conducted are heavily biased towards tropical lowland forests although tropical montane forests cover about $9 \%$ of the tropical forest area (Aragao et al. 2009), tend to contain more soil carbon (Girardin et al. 2010), and are one of the most sensitive forest ecosystems to climate change (Pounds et al. 1999, Still et al. 1999). In a Costa Rican Nrich lowland forest, soil respiration increased after three years of $\mathrm{N}$ addition $(150 \mathrm{~kg} \mathrm{~N}$ $\mathrm{ha}^{-1} \mathrm{yr}^{-1}$ ) due to a stimulation of root respiration, while soil respiration increased after

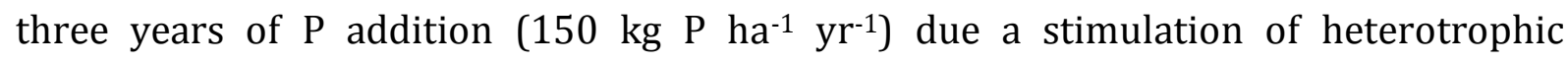
respiration (Cleveland \& Townsend 2006). In contrast, soil respiration decreased in a Puerto Rican N-rich lower elevation forest after three years of $\mathrm{N}$ addition $\left(50 \mathrm{~kg} \mathrm{~N} \mathrm{ha}^{-1}\right.$ $\mathrm{yr}^{-1}$ ) due to a decline in root respiration (Cusack et al. 2010). Tropical montane forests differ from $\mathrm{N}$-rich lowland forests in that they are commonly limited by $\mathrm{N}$ or co-limited by $\mathrm{N}$ and $\mathrm{P}$ (Tanner et al. 1998) but there is only one nutrient-addition experiment that 
has evaluated soil respiration in N-limited tropical montane forests. In a Panamanian Nlimited montane forest, soil respiration decreased after two years of $\mathrm{N}$ addition $(125 \mathrm{~kg}$ $\mathrm{N} \mathrm{ha}^{-1} \mathrm{yr}^{-1}$ ) due to a shift in carbon partitioning from below to aboveground, promoting stem diameter growth.

These different responses of nutrient addition to soil respiration may depend on the amount of nutrient added, soil characteristics (Koehler et al. 2009) and the nutrient status of the soil and the vegetation.

In this study we evaluate how moderate rates of $\mathrm{N}$ and $\mathrm{P}$ additions (50 kg N ha-1

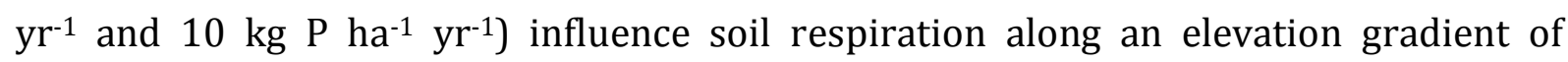
tropical montane forests. We tested the hypothesis that soil respiration will decrease, where nutrient limitation of vegetation growth is alleviated following the addition of the respective nutrient. From January 2008 to September 2009, we measured soil respiration and aboveground litterfall at three elevations. We discovered that at $1000-\mathrm{m}$ elevation, where stem diameter growth did not respond to $\mathrm{N}$ and $\mathrm{P}$ addition (J. Homeier, unpublished results), soil respiration also did not respond to nutrient additions. At 2000-m elevation, where vegetation growth did not respond to nutrient additions (J. Homeier, unpublished results), soil respiration increased in the $\mathrm{N}$-addition plots after the fourth $\mathrm{N}$ addition in 2009. At 3000-m elevation, where vegetation growth likewise did not respond to nutrient additions (J. Homeier, unpublished results), soil respiration increased already after the second $\mathrm{N}$ addition in 2008. We speculate that this increase is caused by a stimulation of heterotrophic respiration in the soil organic layer at the higher elevation sites. Our results illustrate the complex reactions of these ecosystems to nutrient alleviation and suggest a potentially strong feedback of elevated $\mathrm{CO}_{2}$ emissions to elevated $\mathrm{N}$ deposition in these sensitive ecosystems. 


\section{MATERIALS AND METHODS}

\subsection{Study area}

We selected three old-growth forest sites along an elevation gradient in the South Ecuadorian province of Zamora Chinchipe on the eastern slopes of the Andes. Bombuscaro: $990-1100 \mathrm{~m}$ above the see level $\left(4.115^{\circ} \mathrm{S}, 78.968^{\circ} \mathrm{W}\right.$; hereafter called the '1000-m site'), Reserva Biologica San Francisco (RBSF): 1950-2100 m (3.982 S, 79.083 W; hereafter called the '2000-m site') and Cajanuma: 2900-3050 m (4.110 S, 79.178 $\mathrm{W}$; hereafter called the '3000-m site'; Table 1). The 1000-m site is in the transition zone between tropical lowland and lower montane forest. The 2000-m site is in the lower to upper montane belt and the 3000-m site is a typical 'elfin forest' and close to the tree line (Leuschner et al. 2007). Each site is species-rich and the most frequent tree families are Moraceae and Sapotaceae at the 1000-m site, Melastomataceae and Euphorbiaceae at the 2000-m site and Cunoniaceae and Clusiaceae at the 3000-m site (J. Homeier, unpublished results). Although the stand height decreased from $\sim 23 \mathrm{~m}$ at the $1000-\mathrm{m}$ site to $\sim 7 \mathrm{~m}$ at the $3000-\mathrm{m}$ site, the mean basal area did not change between sites due to an increase in stem density of $\sim 40 \%$ with increasing elevation (Table 1 ). Along this elevation gradient, mean annual temperature decreased while mean annual rainfall increased (Moser et al. 2007). Rainfall showed little seasonality (Emck 2008) and ambient nitrogen deposition ranged from 1.5 to $4.4 \mathrm{~kg} \mathrm{~N} \mathrm{ha}^{-1} \mathrm{yr}^{-1}$ in the study area (Fabian et al. 2005).

At all sites, soil characteristics were determined in December 2007, before the first nutrient addition. While Cambisols and Histosols developed on metamorphic schists at the 2000-m and 3000-m site (slopes up to 36\%), Cambisols developed on deeply weathered granitic rock at the 1000-m site (slopes up to 21\%) (Litherland et al. 1994). At the 2000-m and 3000-m sites, the mineral soil was covered with a thick organic layer at the surface which consisted of decomposing leaves (L layer), a 
fermentation layer (Of), and a humus layer (Oh) while only an L layer was present at the 1000-m site.

Table 1. Site and forest characteristics at the three forest sites and forest productivity determined from the control plots.

\begin{tabular}{lccc}
\hline & \multicolumn{3}{c}{ Elevation (m) site } \\
\cline { 2 - 4 } Forest site characteristics & 1000 (Bombuscaro) & 2000 (RBSF) & 3000 (Cajanuma) \\
\hline Coordinates & $04^{\circ} 06^{\prime} \mathrm{S}, 78^{\circ} 58^{\prime} \mathrm{W}$ & $03^{\circ} 59^{\prime} \mathrm{S}, 79^{\circ} 05^{\prime} \mathrm{W}$ & $04^{\circ} 07^{\prime} \mathrm{S}, 79^{\circ} 11^{\prime} \mathrm{W}$ \\
Height above see level $(\mathrm{m})$ & $990-1100$ & $1950-2100$ & $2900-3050$ \\
Air temperature $\left({ }^{\circ} \mathrm{C}\right)^{\mathrm{a}}$ & 19.4 & 15.7 & 9.4 \\
Precipitation $\left(\mathrm{mm} \mathrm{yr} \mathrm{r}^{-1}\right)^{\mathrm{a}}$ & 2230 & 1950 & 4500 \\
Stand height (m) & $20-25$ & $10-14$ & $6-8$ \\
Organic layer thickness $(\mathrm{cm}) \mathrm{c}$ & - & $18.4(4.1)$ & $22.3(6.0)$ \\
Mean basal area $\left(\mathrm{m}^{2} \mathrm{ha}^{-1}\right)^{\mathrm{b}}$ & 33.4 & 22.8 & 25.5 \\
Tree density (trees ha-1 ${ }^{\mathrm{b}}$ & 747.5 & 1142.5 & 1305 \\
Total litterfall $\left(\mathrm{Mg} \mathrm{ha}^{-1} \mathrm{yr}^{-1}\right)^{\mathrm{c}}$ & $8.1(0.4) \mathrm{b}$ & $4.4(0.5) \mathrm{a}$ & $3.5(0.5) \mathrm{a}$ \\
Basal area increment $\left(\mathrm{m}^{2} \mathrm{ha}^{-1} \mathrm{yr}^{-1}\right)^{\mathrm{b}}$ & 0.7 & 0.4 & 0.3 \\
\hline
\end{tabular}

a Moser et al. (2007)

b J. Homeier (unpublished results)

c Means $( \pm \mathrm{SE}, n=4)$ with different lowercase letters indicate significant differences among elevations (one-way ANOVA with Tukey HSD at $P \leq 0.05$ ).

\subsection{Experimental design}

At each site $(1000 \mathrm{~m}, 2000 \mathrm{~m}$ and $3000 \mathrm{~m})$ we laid out a factorial NP fertilization experiment (i.e. N, P, NP, control) with three replicates (20 x $20 \mathrm{~m})$ plots was across 12 plots in a stratified random design. The three replicate strata covered short topographic gradients and were treated as statistical blocks, as nutrient availability and other soil factors can vary over relatively small topographic gradients in these forests (Wolf et al., unpublished data). All blocks were located within the same type of forest. Fertilizer treatments, applied twice a year began in February 2008. Fertilizers were applied to 
reach the following total doses for each year's two applications: $50 \mathrm{~kg} \mathrm{~N}^{-1} \mathrm{year}^{-1}$ (as urea $\left(\mathrm{NH}_{2}\right)_{2} \mathrm{CO}$ ), $10 \mathrm{~kg} \mathrm{P}$ ha-1 year-1 as $\mathrm{NaH}_{2} \mathrm{PO}_{4} \cdot 2 \mathrm{H}_{2} \mathrm{O}$ in pro analysi quality. We applied these moderate amounts of $\mathrm{N}$ and $\mathrm{P}$ to analyze whether a cumulative effect with time causes changes and to simulate nutrient amendments that are closer to deposition values than most fertilizer experiments that have been done in tropical forests. Chamber bases for gas flux measurements were covered during plot fertilizer addition and received the exact amount of fertilizer relative to their area afterwards.

\subsection{Soil respiration}

Soil respiration was measured using static vented chambers. Four permanent chamber bases with a base area of $0.04 \mathrm{~m}^{2}$ and a base height of $0.25 \mathrm{~m}$ were randomly placed two each along two perpendicular random transects and had at least $2 \mathrm{~m}$ distance to the border of the plot to reduce edge effects. Four gas samples were removed at 2, 14, 26 and 38 minutes after chamber closure and stored in pre-evacuated glass containers (60 $\mathrm{mL}$ ). Gas samples were transported to the soil science laboratory at the UTPL University in Loja, Ecuador within 24 hours and analyzed using a gas chromatograph (Shimadzu GC-14B, Duisburg, Germany) equipped with an electron capture detector (ECD) and an autosampler (Loftfield et al. 1997). Gas concentrations were calculated by comparison of integrated peak areas of samples to standard gases $\left(350,700,1500,5000 \mathrm{ppm} \mathrm{CO}_{2}\right.$; Deuste Steininger $\mathrm{GmbH}$, Mühlhausen, Germany). $\mathrm{CO}_{2}$ fluxes were calculated from the increase of gas concentration in the chamber vs. time, and were adjusted for air temperature and atmospheric pressure (Koehler et al. 2009). Gravimetric soil water content and soil temperature was measured in the field parallel to the gas flux measurements. Moisture content was expressed as the percentage of water-filled pore space (WFPS), assuming a particle density of $2.65 \mathrm{~g} \mathrm{~cm}^{-3}$ for mineral soil and $1.4 \mathrm{~g} \mathrm{~cm}^{-3}$ for organic layer (Breuer et al. 2002). Annual $\mathrm{CO}_{2}$ fluxes were estimated by linear interpolation of the monthly measurements, which assumes that $\mathrm{CO}_{2}$ fluxes of a sampling day are representative of the unmeasured days. We conducted $\mathrm{CO}_{2}$-flux and 
ancillary measurements once per month from January 2008 until September 2009. For practical reasons, we sampled one block at one elevation per sampling day. We excluded any measurement within four weeks following fertilization from our analysis because we were not interested in the short term but in the mid to long term effects. One pretreatment measurement at each site indicated that initial $\mathrm{CO}_{2}$ fluxes did not differ between control and the other treatment plots before fertilization started.

\subsection{Litterfall and litter nutrients and nutrient use efficiencies}

Six Litter traps $(60 \times 60 \mathrm{~cm})$ were randomly placed three each along two perpendicular random transects and had at least $2 \mathrm{~m}$ distance to the border of the plot to reduce edge effects. Total litterfall per plot was collected monthly. Total litterfall, including leaves, twigs, epiphytes, flowers and fruits, was oven-dried at $60^{\circ} \mathrm{C}$ before determining the dry weight. Leaf litter nutrient were measured once in November 2008. Total C and $\mathrm{N}$ of litter samples were determined by a CNS Elemental Analyzer (Elementar Vario EL, Hanau, Germany) and total $\mathrm{P}$ and total base cations by pressure digestion in concentrated $\mathrm{HNO}_{3}$ (König \& Fortmann 1996) followed by analysis of the digests using inductively coupled plasma-atomic emission spectrometer (ICP-AES; Spectro Analytical Instruments, Kleve, Germany). The nutrient input of aboveground litterfall for each plot was derived from the product of nutrient concentrations of the litter and total annual litter fall. N- and P use efficiencies of litterfall were calculated at each site once in 2008. It is defined as the leaf litter production per unit of nutrient take up or nutrient available (Birk \& Vitousek 1986). 


\subsection{Statistical analysis}

Statistics were carried out on the plot mean (average of four chambers and of six litter traps per plot). Data were tested for normality and heteroscedasticity and transformed if necessary. We used linear mixed effects models (lme) for analysis of time-series data (Crawley 2010). When testing for differences among N, P and N+P addition and control plots, treatment was included in the model as a fixed effect and the blocks nested in time as a random effect. The significance of the fixed effect was determined based on analysis of variance (Crawley 2010). For annual C fluxes, the treatment effects were assessed using one-way analysis of variance (ANOVA). The Tukey HSD test was used for multiple comparisons among treatments. The level of significance was defined as $P \leq 0.05$. All analyses were conducted using R 2.10.1 (R Development Core Team, 2009).

\section{RESULTS}

\subsection{Soil $\mathrm{CO}_{2}$ efflux and total litterfall in the control forests}

At the top $0.05-\mathrm{m}$ depth soil temperature varied between $15.0^{\circ} \mathrm{C}$ and $18.6^{\circ} \mathrm{C}$ at the 1000 $\mathrm{m}$, between $9.0^{\circ} \mathrm{C}$ and $14.4^{\circ} \mathrm{C}$ at the $2000-\mathrm{m}$ and between $2.6^{\circ} \mathrm{C}$ and $5.3^{\circ} \mathrm{C}$ at the $3000-\mathrm{m}$ site (Figure 1a). At top 0.05-m depth WFPS varied between $56.9 \%$ and $88.5 \%$ at the $1000-\mathrm{m}$ site, between $27.6 \%$ and $61.5 \%$ at the $2000-\mathrm{m}$ site and between $17.9 \%$ and $57.8 \%$ at the $3000-\mathrm{m}$ site without any clear seasonal pattern at all elevations (Figure $1 b)$. 

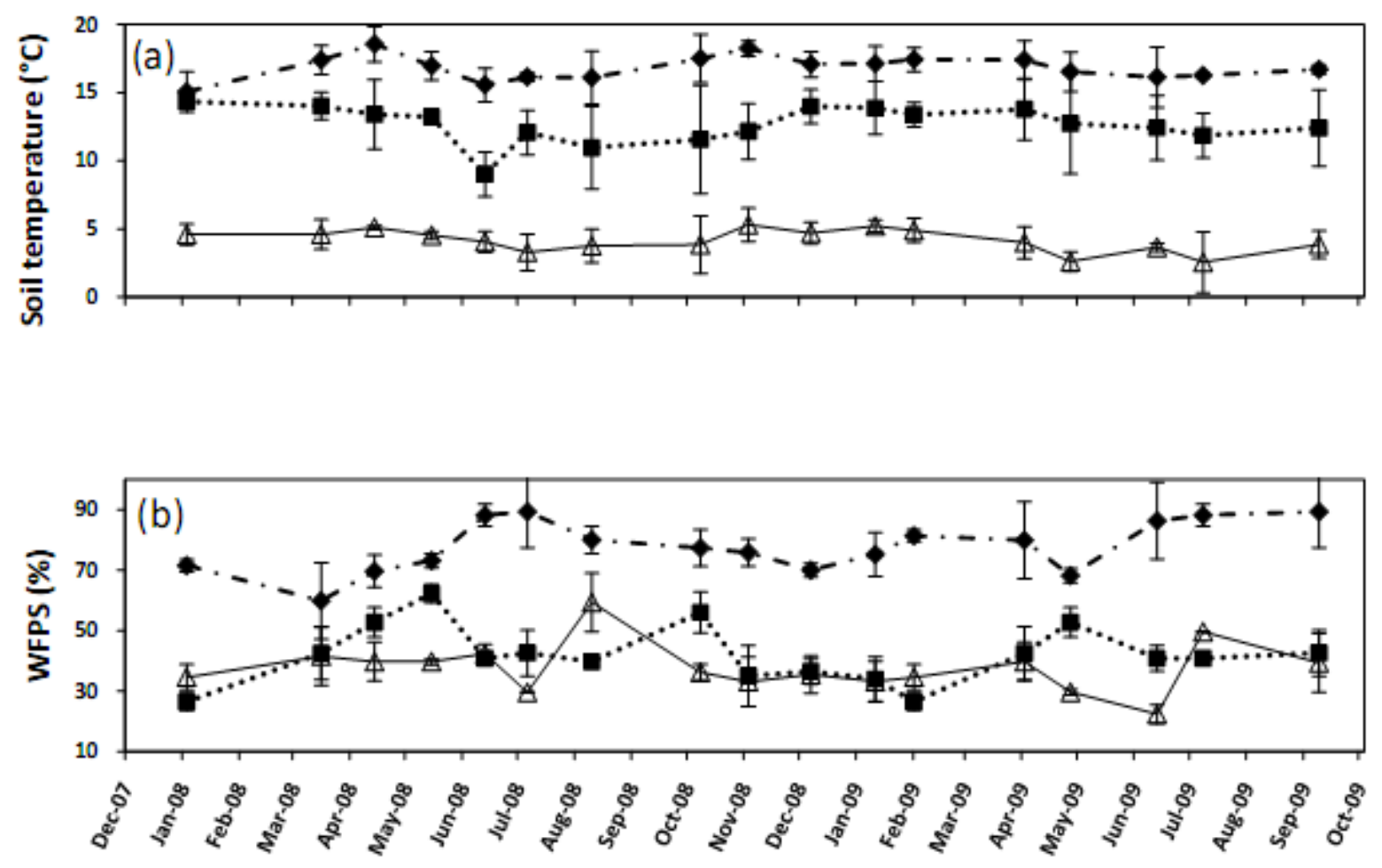

Figure 1. a) Mean ( $\pm S E, n=3$ ) soil temperature (b) and water-filled pore space (WFPS) (b) at the top 0.05-m soil depth in control plots at the 1000-m (^), 2000-m (घ) and 3000-m sites $(\Delta)$.

Soil $\mathrm{CO}_{2}$ efflux differed between each elevation and decreased from the 1000-m (109.33 $\pm 4.61 \mathrm{mg} \mathrm{C} \mathrm{m}^{-2} \mathrm{~h}^{-1}$, Figure 2a) to the $2000-\mathrm{m}\left(74.80 \pm 2.76 \mathrm{mg} \mathrm{C} \mathrm{m}^{-2} \mathrm{~h}^{-1}\right.$, Figure $\left.2 \mathrm{~b}\right)$ and to the 3000 -m site $\left(31.51 \pm 3.19 \mathrm{mg} \mathrm{C} \mathrm{m}^{-2} \mathrm{~h}^{-1}\right.$, Figure $\left.2 \mathrm{c}\right)$. Annual soil $\mathrm{CO}_{2}$ efflux ranged

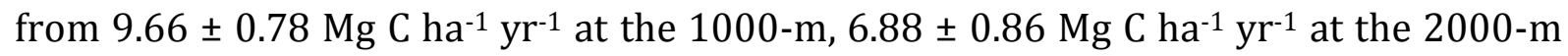
and $3.23 \pm 0.49 \mathrm{Mg} \mathrm{C} \mathrm{ha}^{-1} \mathrm{yr}^{-1}$ at the 3000-m site (Figure 5). Soil $\mathrm{CO}_{2}$ efflux showed no seasonal pattern over the whole study period at any of the elevations (Figure 2) except at the 1000-m site, where average soil $\mathrm{CO}_{2}$ efflux decreased from May 2008 (117.78 \pm $\left.7.15 \mathrm{mg} \mathrm{C} \mathrm{m}^{-2} \mathrm{~h}^{-1}\right)$ to October $2008\left(75.30 \pm 28.28 \mathrm{mg} \mathrm{C} \mathrm{m}^{-2} \mathrm{~h}^{-1}\right)$ and again increased thereafter. However, soil $\mathrm{CO}_{2}$ efflux was not correlated with soil temperature or WFPS. 
Total litterfall was highest at the $1000-\mathrm{m}$ site and decreased with increasing elevation but did not differ between the 2000-m and 3000-m site (Table 1). The $\mathrm{N}$ use efficiency differed between each elevation and decreased with increasing elevation (Figure 6a). At the 2000-m site, the P use efficiency was higher compared to the 1000-m and 2000-m site but did not differ between the 1000-m and 3000-m site (Figure 5b).

\subsection{Nutrient addition effects on soil $\mathrm{CO}_{2}$ efflux and total litterfall}

At the 1000-m site, soil $\mathrm{CO}_{2}$ efflux did not differ between the control and the nutrientaddition plots in 2008 and 2009 (Figure 2a). At the 2000-m site, soil $\mathrm{CO}_{2}$ efflux did not differ between the control and the nutrient-addition plots in 2008 but was higher in the $\mathrm{N}$-addition plots compared to the control plots after the third and fourth nutrient addition in 2009 (Figure 2b). At the 3000 site, soil $\mathrm{CO}_{2}$ efflux was higher in the Naddition plots compared to the control plots after the first and second nutrient addition in 2008 (Figure 2c) and also after the third and fourth nutrient addition in 2009 (Figure $2 c)$. 

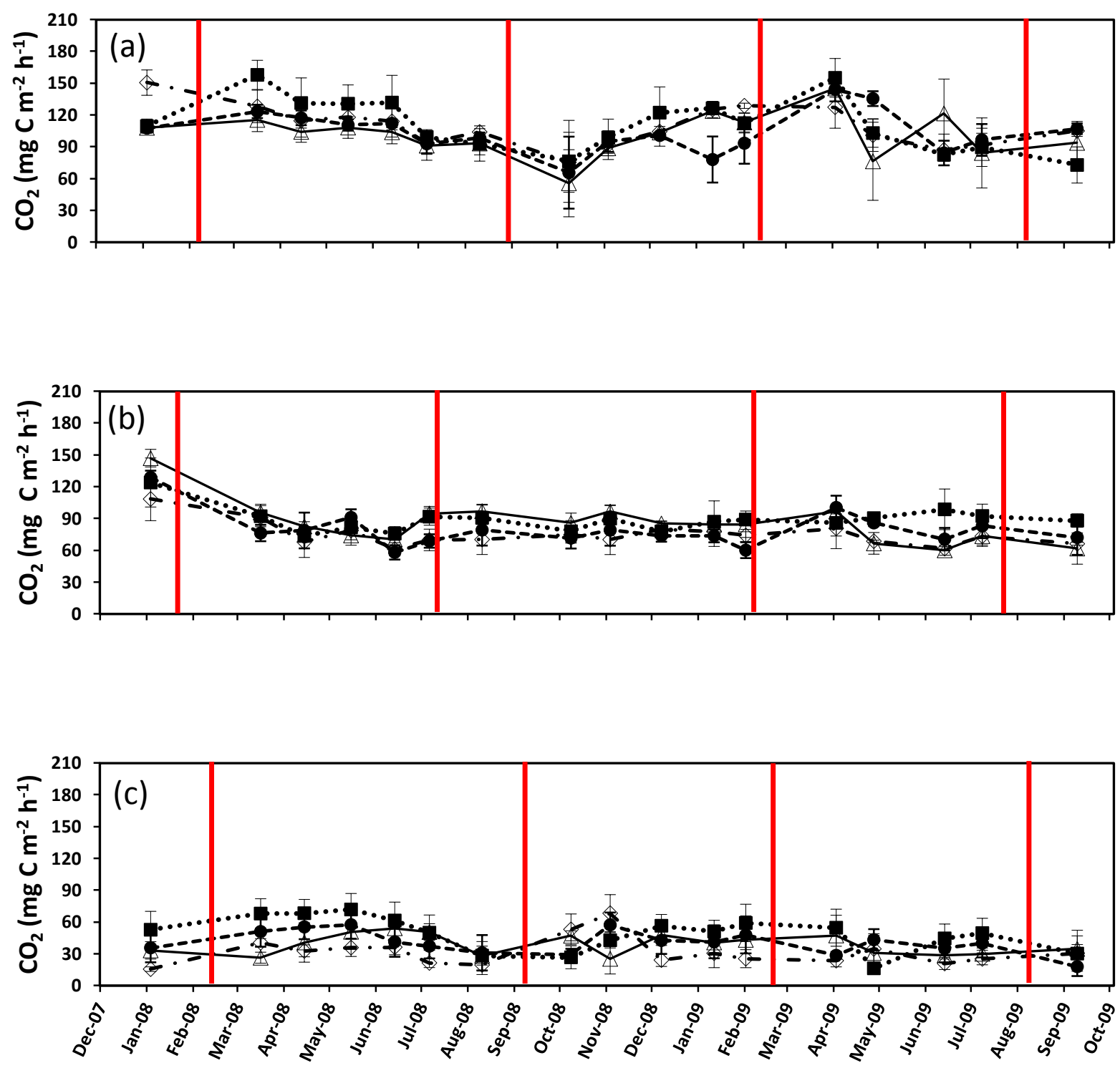

Figure 2. Mean ( $\pm \mathrm{SE}, n=3$ ) soil $\mathrm{CO}_{2}$ efflux at (a) 1000-m (b) 2000-m and (c) 3000-m site. ( 0 ) indicate control plots, $(\square)$ indicate nitrogen plots, $(\bullet)$ indicate phosphorus plots and $(\Delta)$ indicate nitrogen+phosphorus plots. Red vertical lines indicate nutrient addition events.

Total litterfall did not differ between the control and nutrient-addition plots at any of the elevations in 2008 (Figure 4). Additionally, the ratio of soil $\mathrm{CO}_{2}$ efflux to monthly total litterfall did not differ between control and nutrient-addition plots at any of the elevations in 2008 and 2009 (Figure 3). 

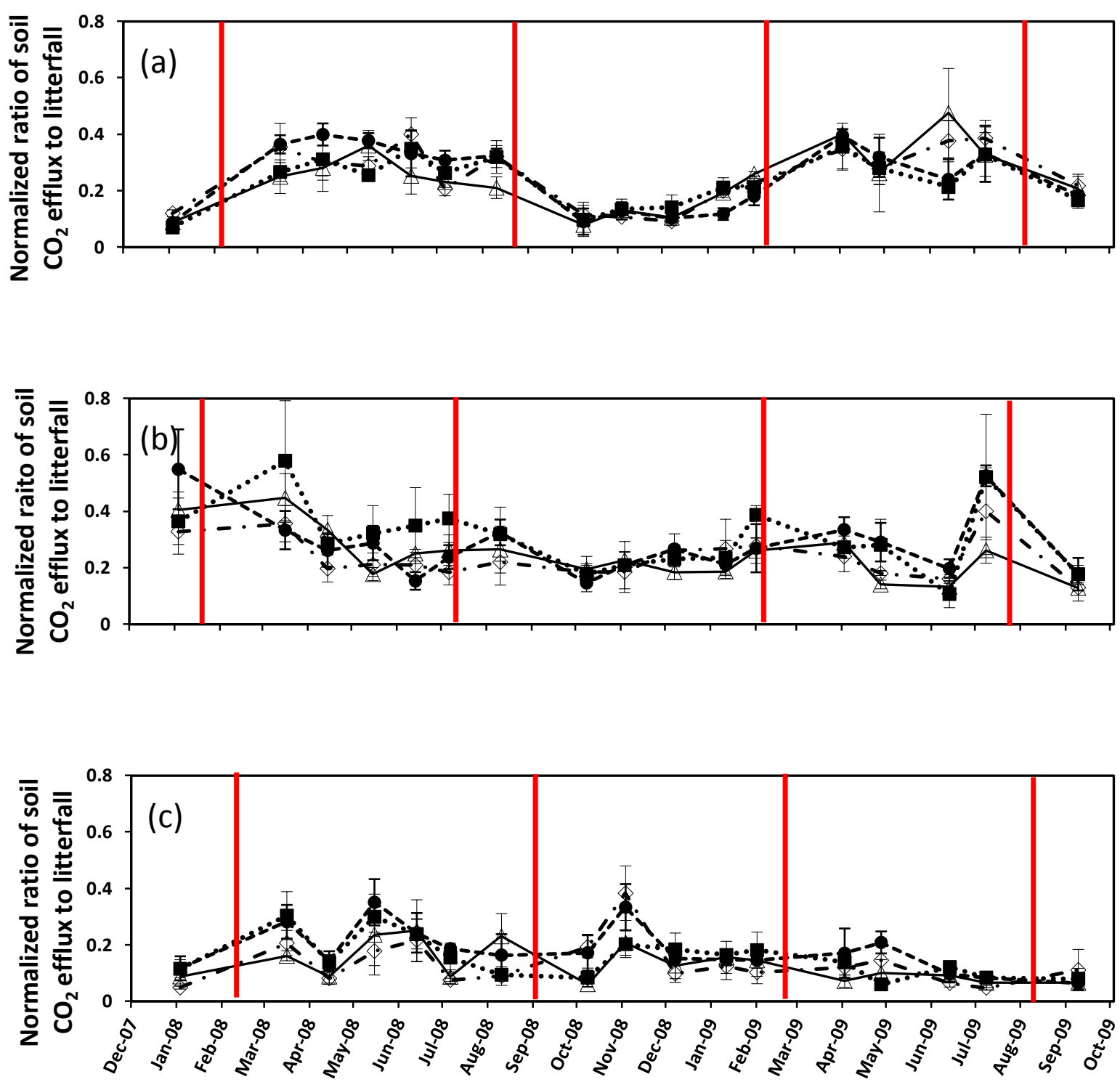

Figure 3. Mean $\left( \pm \mathrm{SE}, n=3\right.$ ) normalized ratio of soil $\mathrm{CO}_{2}$ efflux to monthly total litterfall at (a) 1000 m (b) 2000-m and (c) 3000-m site. ( $(0)$ indicate control plots, ( $(\bullet)$ indicate nitrogen plots, (•) indicate phosphorus plots and $(\Delta)$ indicate nitrogen+phosphorus plots. Red vertical lines indicate nutrient addition events. 


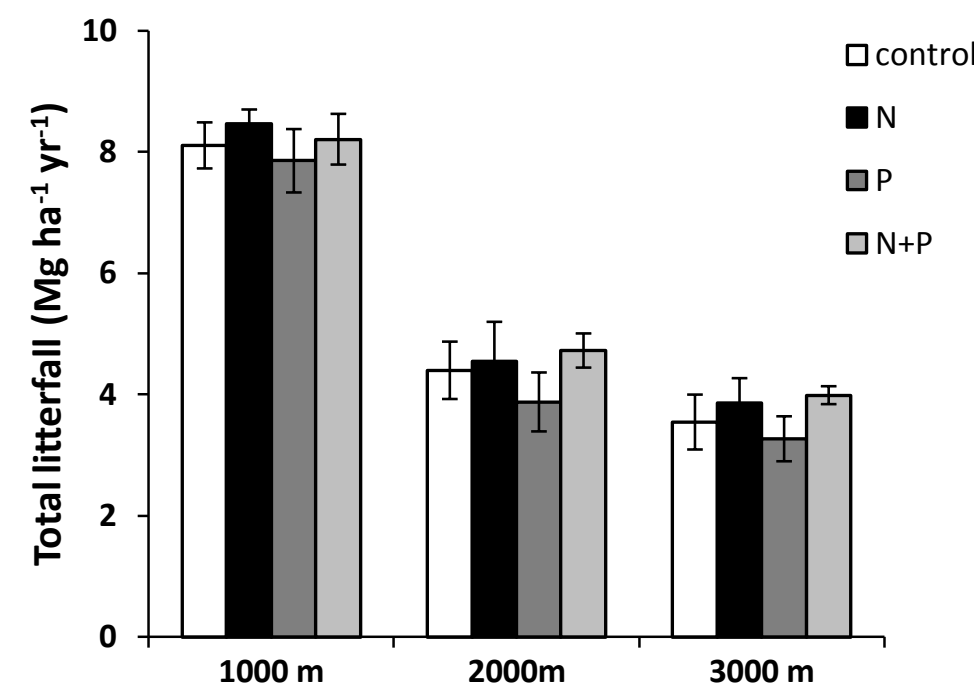

Figure 4. Total litterfall (mean $\pm \mathrm{SE}, n=3$ ) at the $1000-\mathrm{m}, 2000-\mathrm{m}$ and $3000-\mathrm{m}$ site after two nutrient applications in the control, $\mathrm{N}$-addition plots, $\mathrm{P}$-addition plots and $\mathrm{N}+\mathrm{P}$-addition plots in 2008.

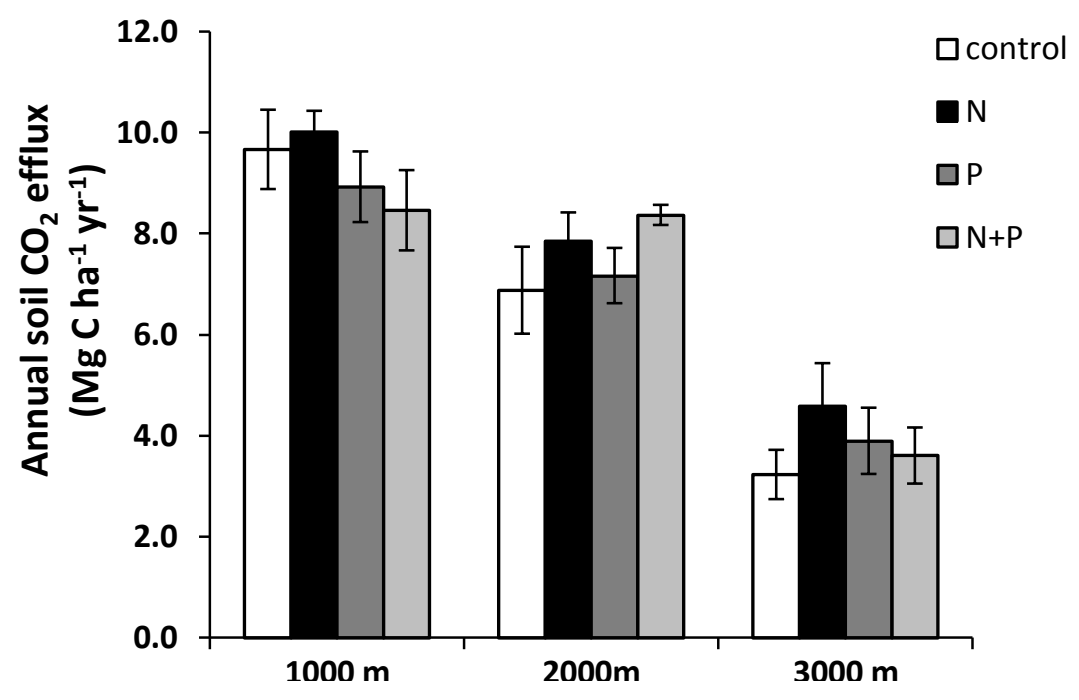

Figure 5. Annual soil $\mathrm{CO}_{2}$ efflux (mean $\pm \mathrm{SE}, n=3$ ) at the $1000-\mathrm{m}, 2000-\mathrm{m}$ and $3000-\mathrm{m}$ site after two nutrient applications in the control, $\mathrm{N}$-addition plots, $\mathrm{P}$-addition plots and $\mathrm{N}+\mathrm{P}$-addition plots in 2008. 
At the 1000-m and 3000-m site, the $\mathrm{N}$ use efficiency did not differ between the control and nutrient-addition plots but decreased in the $\mathrm{N}$ - and $\mathrm{N}+\mathrm{P}$-addition plots at the 2000-m site after the second nutrient addition in 2008 (Figure 6a). At the 1000-m and 3000-m site, the P use efficiency did not differ between control and nutrient-addition plots but was higher in the $\mathrm{N}+\mathrm{P}$-addition plots compared to the control plots at the 2000-m site after the second nutrient addition in 2008 (Figure 6b). 

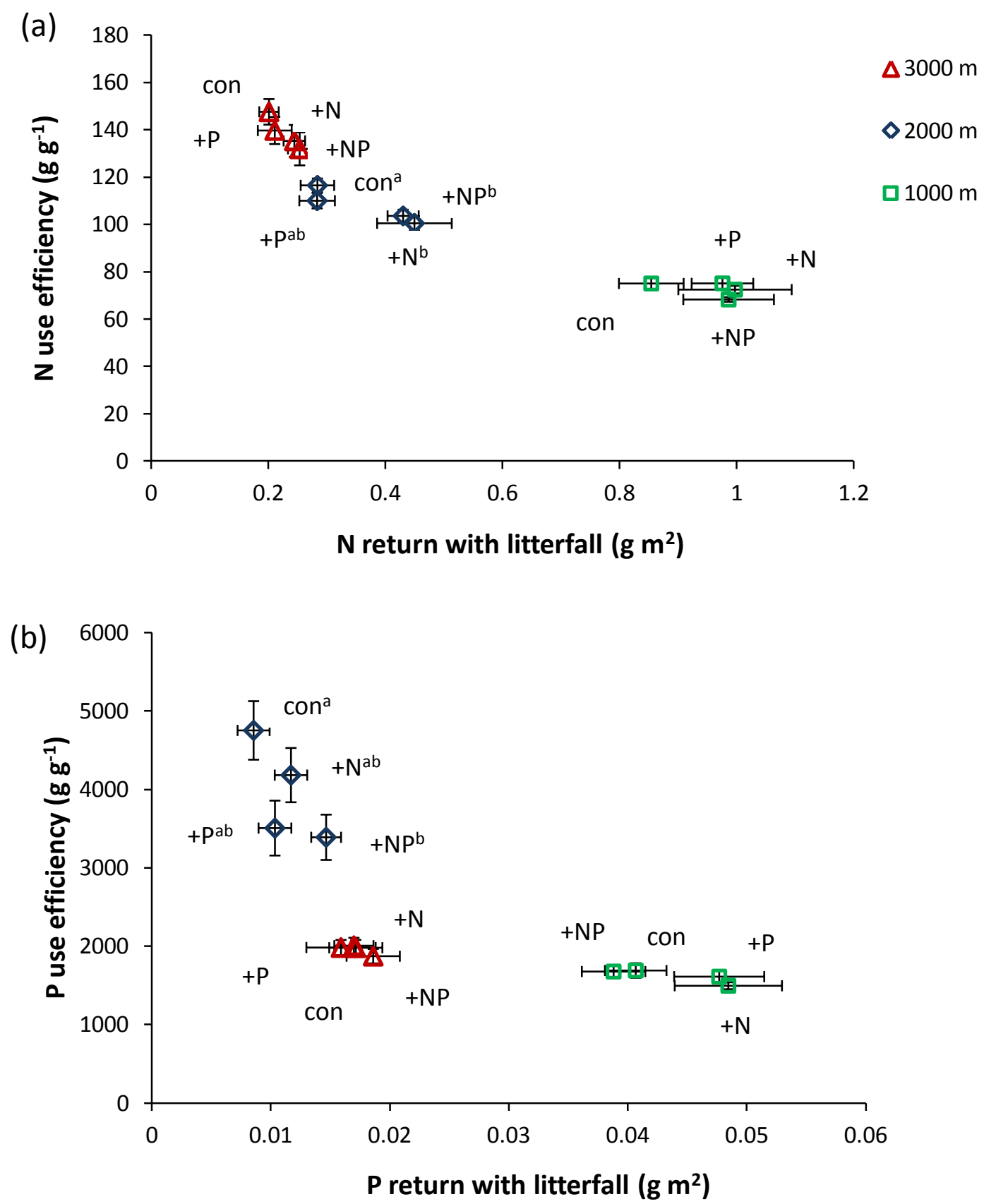

Figure 6. $\mathrm{N}$ use efficiency (a) and $\mathrm{P}$ use efficiency (b) (i.e. the ratio of total litterfall dry mass to nutrient content; after Vitousek 1984) and monthly nutrient return with litterfall of the different treatments in the studied montane forest in Ecuador after one year of nutrient addition (samples from January 2009, means of $n=24$ litter traps per treatment \pm SE), different letters indicate significant differences in the nutrient use efficiency of the treatments (ANOVA, Tukey HSD test). 


\section{DISCUSSION}

\subsection{Soil $\mathrm{CO}_{2}$ efflux and total litterfall in control forest plots}

The rates of soil $\mathrm{CO}_{2}$ efflux at our study sites were at the lower limit of other reported values for tropical montane forests (Cusack et al. 2010, Koehler et al. 2009, McGroddy \& Silver 2000, Priess \& Folster 2001, Raich 1998). The decreasing soil $\mathrm{CO}_{2}$ efflux with increasing elevation (Figure 2) may be primarily controlled by the forest's temperature and moisture regime (Table 1). Wolf et al. (unpublished data) reported that soil respiration was largely derived from the decomposition of surface litter and was mainly controlled by temperature and soil moisture at the same sites. The lower soil temperature at the two higher elevation sites may hamper soil microbial activity and lead to reduced soil respiration rates (Atkin \& Tjoelker 2003) (Figure 2) and accumulation of organic matter. Furthermore, total litterfall was reduced (Table 1) and nutrient use efficiencies were larger at the two higher elevation sites (Figure 6) indicating that nutrient availability was reduced at the $2000-\mathrm{m}$ and $3000-\mathrm{m}$ site compared to the $1000-\mathrm{m}$ site.

The decrease of the normalized ratio of monthly soil $\mathrm{CO}_{2}$ efflux to monthly total litterfall at the 1000-m site from August 2008 to October 2008 (Figure 3) was mainly caused by the seasonality of monthly total litterfall, with lower litterfall from March to August 2008 and higher litterfall from October 2008 to February 2009. Small changes in rates of precipitation may have induced these changes in litterfall because our data on soil temperature and WFPS that were measured once per month failed to explain the observed phenology of litterfall. Hence, the relatively small decrease of soil $\mathrm{CO}_{2}$ efflux from May to October 2008 (Figure 2) may primarily be caused by decreased litterfall and therefore decreased substrate availability (Yuste et al. 2004) in the same time period. 


\subsection{Nutrient controls on soil respiration and leaf litter production}

Although we are not able to distinguish between autotrophic and heterotrophic respiration because we measured bulk soil respiration, a possible explanation for the positive effect of $\mathrm{N}$ addition on soil respiration at the 2000-m and 3000-m site (Figure $2 \mathrm{~b}, \mathrm{c}$ ) may be an increase of microbial biomass in the organic layer at both sites, as has been found in Panamanian tropical montane forests with thick organic layers after $\mathrm{N}$ addition (Corre et al. 2010). Janssens et al. (2010) suggested that microbial biomass may grow following $\mathrm{N}$ addition, leading to enhanced enzyme production and increased soil respiration in severely nitrogen limited forests, such as tropical montane forests with thick organic layers. Another possible explanation for the positive effect of N- addition on soil respiration at the two higher elevation sites is that increased litter production following $\mathrm{N}$ - addition in our study area, although significant increases were only detected in the $\mathrm{N}+\mathrm{P}$-addition plots after the fourth nutrient addition at the $2000-\mathrm{m}$ site in 2009 (J. Homeier, unpublished results), may have caused a natural priming effect on the microbial community in the organic layer, with an enhanced respiratory response to high labile C availability (Cleveland \& Townsend 2006, Kuzyakov 2010, Luo \& Zhou 2006). At the 3000-m site, soil respiration responded to $\mathrm{N}$ addition faster than at the 2000-m site (Figure $2 \mathrm{~b}, \mathrm{c}$ ). We attribute this faster response of soil respiration to $\mathrm{N}$ addition at the $3000-\mathrm{m}$ site compared to the $2000-\mathrm{m}$ site to an increase in $\mathrm{N}$ limitation with increasing elevation, as indicated by the increasing $\mathrm{N}$ use efficiency with increasing elevation (Figure 6a). The normalized ratio of monthly soil $\mathrm{CO}_{2}$ efflux to monthly total litterfall did not change following nutrient addition at our sites. Therefore, we suggest that $\mathrm{N}$ limitation of decomposition processes in the organic layer and their effects on heterotrophic respiration are more pronounced than $\mathrm{N}$ limitation of vegetation growth and their effects on autotrophic respiration at the two higher elevation sites. Our results contrasts the current opinion that a decrease in $\mathrm{N}$ limitation should induce a shift in $\mathrm{C}$ partitioning from below to aboveground and lead to a reduced autotrophic respiration (Janssens et al. 2010) as has been observed in Panamanian tropical montane forest soils (Koehler et al. 2009). In a Panamanian montane forest at 1250-m elevation, where stem 
diameter growth was $\mathrm{N}$ limited and $\mathrm{N}$ addition (125 $\mathrm{kg} \mathrm{N} \mathrm{ha}^{-1} \mathrm{yr}^{-1}$ ) led to an increase in stem diameter growth along with a reduction of soil respiration in the respective plots. This decrease of soil respiration was attributed to a shift in carbon partitioning from below to aboveground (Koehler et al. 2009). A possible explanation of this contrasting response on soil respiration may be the different amount of $\mathrm{N}$ fertilizer applied in the nutrient-addition experiments. In the Panamanian $\mathrm{N}$-addition experiment the amount of $\mathrm{N}$ applied may have been sufficiently high to induce a shift in $\mathrm{C}$ partitioning from below to aboveground and to mask any possible positive $\mathrm{N}$-addition effect on heterotrophic respiration, while the relatively low amount of $\mathrm{N}$ fertilizer (50 kg N ha-1 yr-1) in our nutrient-addition experiment stimulated heterotrophic respiration but was not able to induce a shift in $\mathrm{C}$ partitioning from below to aboveground. It remains to be seen whether soil respiration will continue to increase following subsequent $\mathrm{N}$ addition at the two higher elevation sites or if a decrease of autotrophic respiration due to an increase of $\mathrm{C}$ partitioning from below to aboveground will eventually compensate the increase in heterotrophic respiration and finally lead to a reduction in soil respiration, as was found in Panamanian tropical montane forest soils (Koehler et al. 2009).

The lack of a nutrient-addition effect on soil respiration and total litterfall at the 1000-m site (Figure 2a) may indicate that microbial biomass remained unchanged in the not $\mathrm{N}$ limited forest at the $1000-\mathrm{m}$ site following $\mathrm{N}$ - addition. In not $\mathrm{N}$ limited forests, lignin degrading enzymes are frequently down-regulated following $\mathrm{N}$-addition, leading to a reduced degradation of more recalcitrant compounds and to a decrease in microbial biomass and heterotrophic respiration (DeForest et al. 2004, Treseder 2008). Therefore, heterotrophic respiration may not have changed at the 1000-m site.

P-addition had no effect on soil respiration and total litterfall. Hence, we suggest that neither decomposition processes nor vegetation growth were P-limited or the amount of added $\mathrm{P}$ may have been insufficient to overcome any potential $\mathrm{P}$ limitation to these processes. Our results are surprising because recent literature reviews show that there is a general negative impact of $\mathrm{N}$ addition on microbial biomass and heterotrophic respiration among different ecosystems together with a shift in $\mathrm{C}$ partitioning from below to aboveground along with a decrease in root biomass and autotrophic 
respiration (Janssens et al. 2010, Liu \& Greaver 2010). However, these literature reviews had not one single measurement from severly $\mathrm{N}$ limited tropical montane forest soils with a thick organic layer. In contrast, our results show that increasing nutrient availability in thick organic layers has a stronger effect on decomposition processes and heterotrophic respiration than on biomass production and autotrophic respiration. The rapid impacts on soil respiration in tropical montane forest soils even by moderate $\mathrm{N}$ additions, suggest that this ecosystem is strongly susceptible to increased nitrogen deposition in the future. 


\section{REFERENCES}

Aragao, L. E. O. C., Y. Malhi, D. B. Metcalfe, J. E. Silva-Espejo, E. Jimenez, D. Navarrete, S. Almeida, A. C. L. Costa, N. Salinas, O. L. Phillips, L. O. Anderson, E. Alvarez, T. R. Baker, P. H. Goncalvez, J. Huaman-Ovalle, M. Mamani-Solorzano, P. Meir, A. Monteagudo, S. Patino, M. C. Penuela, A. Prieto, C. A. Quesada, A. Rozas-Davila, A. Rudas, J. A. Silva, and R. Vasquez. 2009. Above- and below-ground net primary productivity across ten Amazonian forests on contrasting soils. Biogeosciences 6:2759-2778.

Atkin, O. K., and M. G. Tjoelker. 2003. Thermal acclimation and the dynamic response of plant respiration to temperature. Trends in Plant Science 8:343-351.

Birk, E. M., P. M. Vitousek. 1986. Nitrogen availability and nitrogen use efficiency in loblolly pine stands. Ecology 67:69-79.

Bown, H. E., M. S. Watt, P. W. Clinton, E. G. Mason, and D. Whitehead. 2009. The influence of $\mathrm{N}$ and $\mathrm{P}$ supply and genotype on carbon flux and partitioning in potted Pinus radiata plants. Tree Physiology 29:857-868.

Breuer, L., R. Kiese, and K. Butterbach-Bahl. 2002. Temperature and moisture effects on nitrification rates in tropical rain-forest soils. Soil Science Society of America Journal 66:834-844.

Cleveland, C. C., and A. R. Townsend. 2006. Nutrient additions to a tropical rain forest drive substantial soil carbon dioxide losses to the atmosphere. Proceedings of the National Academy of Sciences of the United States of America 103:10316-10321.

Corre, M. D., E. Veldkamp, J. Arnold, and S. J. Wright. 2010. Impact of elevated N input on soil N cycling and losses in old-growth lowland and montane forests in Panama. Ecology 91:1715-1729. 
Crawley M. J. 2010. The R book. John Wiley \& Sons Ltd, Chinchester, West Sussex.

Cusack,D.F., W.L.Silver, M.S.Torn, and W.H.McDowell 2010. Effects of nitrogen additions on above- and belowground carbon dynamics in two tropical forests. Biogeochemistry, DOI 10.1007/s10533-010-9496-4.

Davidson, E. A., L. V. Verchot, J. H. Cattanio, I. L. Ackerman, and J. E. M. Carvalho. 2000. Effects of soil water content on soil respiration in forests and cattle pastures of eastern Amazonia. Biogeochemistry 48:53-69.

DeForest, J. L., D. R. Zak, K. S. Pregitzer, and A. J. Burton. 2004. Atmospheric nitrate deposition and the microbial degradation of cellobiose and vanillin in a northern hardwood forest. Soil Biology \& Biochemistry 36:965-971.

Elser, J. J., M. E. S. Bracken, E. E. Cleland, D. S. Gruner, W. S. Harpole, H. Hillebrand, J. T. Ngai, E. W. Seabloom, J. B. Shurin, and J. E. Smith. 2007. Global analysis of nitrogen and phosphorus limitation of primary producers in freshwater, marine and terrestrial ecosystems. Ecology Letters 10:1135-1142.

Emck P. 2008. A climatology of south Ecuador: with special focus on the major Andean climate divide. Vdm Verlag.

Fabian, P., M. Kohlpaintner, and R. Rollenbeck. 2005. Biomass burning in the Amazonfertilizer for the mountaineous rain forest in Ecuador. Environmental Science and Pollution Research 12:290-296.

Finzi, A. C., A. T. Austin, E. E. Cleland, S. D. Frey, B. Z. Houlton, and M. D. Wallenstein. 2011. Responses and feedbacks of coupled biogeochemical cycles to climate change: examples from terrestrial ecosystems. Frontiers in Ecology and the Environment 9:61-67.

Giardina, C. P., M. D. Coleman, J. E. Hancock, J. S. King, E. A. Lilleskov, W. M. Loya, K. S. Pregitzer, M. G. Ryan, and C. C. Trettin. 2005. The response of belowground carbon allocation in forests to global change. Pages 119-154 in D. Binkley, and O. 
Menyailo editors. Tree Species Effects on Soils: Implications For Global Change. Kluwer Academic, Dordrecht.

Girardin, C. A. J., Y. Malhi, L. E. O. C. Aragao, M. Mamani, W. H. Huasco, L. Durand, K. J. Feeley, J. Rapp, J. E. Silva-Espejo, M. Silman, N. Salinas, and R. J. Whittaker. 2010. Net primary productivity allocation and cycling of carbon along a tropical forest elevational transect in the Peruvian Andes. Global Change Biology 16:3176-3192.

Janssens, I. A., W. Dieleman, S. Luyssaert, J. A. Subke, M. Reichstein, R. Ceulemans, P. Ciais, A. J. Dolman, J. Grace, G. Matteucci, D. Papale, S. L. Piao, E. D. Schulze, J. Tang, and B. E. Law. 2010. Reduction of forest soil respiration in response to nitrogen deposition. Nature Geoscience 3:315-322.

Koehler, B., M. D. Corre, E. Veldkamp, and J. P. Sueta. 2009. Chronic nitrogen addition causes a reduction in soil carbon dioxide efflux during the high stem-growth period in a tropical montane forest but no response from a tropical lowland forest on a decadal time scale. Biogeosciences 6:2973-2983.

König N., and H. Fortmann. 1996. Probenvorbereitungs-, Untersuchungs- und Elementbestimmungs-Methoden des Umweltanalytik-Labors der Niedersächsichen Forstlichen Versuchsanstalt. University of Goettingen, Goettingen, Germany.

Kuzyakov, Y. 2010. Priming effects: Interactions between living and dead organic matter. Soil Biology \& Biochemistry 42:1363-1371.

Leuschner, C., G. Moser, C. Bertsch, M. Roderstein, and D. Hertel. 2007. Large altitudinal increase in tree root/shoot ratio in tropical mountain forests of Ecuador. Basic and Applied Ecology 8:219-230.

Litherland, M., J. A. Aspden, and R. A. Jemielita. 1994. The metamorphic belts of Ecuador. Overseas Memoir 11. 
Litton, C. M., and C. P. Giardina. 2008. Below-ground carbon flux and partitioning: global patterns and response to temperature. Functional Ecology 22:941-954.

Litton, C. M., J. W. Raich, and M. G. Ryan. 2007. Carbon allocation in forest ecosystems. Global Change Biology 13:2089-2109.

Liu, L. L., and T. L. Greaver. 2010. A global perspective on belowground carbon dynamics under nitrogen enrichment. Ecology Letters 13:819-828.

Livingston, G. P., G. L. Hutchinson, and K. Spartalian. 2006. Trace gas emission in chambers: A non-steady-state diffusion model. Soil Science Society of America Journal 70:1459-1469.

Loftfield, N., H. Flessa, J. Augustin, and F. Beese. 1997. Automated gas chromatographic system for rapid analysis of the atmospheric trace gases methane, carbon dioxide, and nitrous oxide. Journal of Environmental Quality 26:560-564.

Luo Y., and X. Zhou. 2006. Soil Respiration and the Environment, Eds. Academic Press, Burlington, San Diegom London.

Magnani, F., M. Mencuccini, M. Borghetti, P. Berbigier, F. Berninger, S. Delzon, A. Grelle, P. Hari, P. G. Jarvis, P. Kolari, A. S. Kowalski, H. Lankreijer, B. E. Law, A. Lindroth, D. Loustau, G. Manca, J. B. Moncrieff, M. Rayment, V. Tedeschi, R. Valentini, and J. Grace. 2007. The human footprint in the carbon cycle of temperate and boreal forests. Nature 447:848-850.

Malhi, Y., L. E. O. C. Aragao, D. B. Metcalfe, R. Paiva, C. A. Quesada, S. Almeida, L. Anderson, P. Brando, J. Q. Chambers, A. C. L. da Costa, L. R. Hutyra, P. Oliveira, S. Patino, E. H. Pyle, A. L. Robertson, and L. M. Teixeira. 2009. Comprehensive assessment of carbon productivity, allocation and storage in three Amazonian forests. Global Change Biology 15:1255-1274.

McGroddy, M., and W. L. Silver. 2000. Variations in belowground carbon storage and soil $\mathrm{CO}_{2}$ flux rates along a wet tropical climate gradient. Biotropica 32:614-624. 
Moser, G., D. Hertel, and C. Leuschner. 2007. Altitudinal change in LAI and stand leaf biomass in tropical montane forests: a transect shady in Ecuador and a pantropical meta-analysis. Ecosystems 10:924-935.

Pounds, J. A., M. P. L. Fogden, and J. H. Campbell. 1999. Biological response to climate change on a tropical mountain. Nature 398:611-615.

Priess, J. A., and H. Folster. 2001. Microbial properties and soil respiration in submontane forests of Venezuelan Guyana: characteristics and response to fertilizer treatments. Soil Biology \& Biochemistry 33:503-509.

Raich, J. W. 1998. Aboveground productivity and soil respiration in three Hawaiian rain forests. Forest Ecology and Management 107:309-318.

Raich, J. W., and K. J. Nadelhoffer. 1989. Belowground carbon allocation in forest ecosystems: global trends. Ecology 70:1346-1354.

Schimel, D. S., B. H. Braswell, R. McKeown, D. S. Ojima, W. J. Parton, and W. Pulliam. 1996. Climate and nitrogen controls on the geography and timescales of terrestrial biogeochemical cycling. Global Biogeochemical Cycles 10:677-692.

Schlesinger, W. H., and J. A. Andrews. 2000. Soil respiration and the global carbon cycle. Biogeochemistry 48:7-20.

Still, C. J., P. N. Foster, and S. H. Schneider. 1999. Simulating the effects of climate change on tropical montane cloud forests. Nature 398:608-610.

Tanner, E. V. J., P. M. Vitousek, and E. Cuevas. 1998. Experimental investigation of nutrient limitation of forest growth on wet tropical mountains. Ecology 79:10-22.

Treseder, K. K. 2008. Nitrogen additions and microbial biomass: a meta-analysis of ecosystem studies. Ecology Letters 11:1111-1120. 
Vitousek, P. M., S. Porder, B. Z. Houlton, and O. A. Chadwick. 2010. Terrestrial phosphorus limitation: mechanisms, implications, and nitrogen-phosphorus interactions. Ecological Applications 20:5-15.

Yuste, J. C., I. A. Janssens, A. Carrara, and R. Ceulemans. 2004. Annual Q(10) of soil respiration reflects plant phenological patterns as well as temperature sensitivity. Global Change Biology 10:161-169. 


\section{CHAPTER V}

SYNTHESIS 


\section{METHANE EMISSIONS FROM CANOPY WETLANDS}

The total global $\mathrm{CH}_{4}$ emissions are about 500 to $600 \mathrm{Tg} \mathrm{CH}_{4}$ per year and wetlands are assumed to be the major $\mathrm{CH}_{4}$ source (Melack \& Hess 2009). In 2005, increased $\mathrm{CH}_{4}$ concentrations above tropical forests were observed by Frankenberg et al. (2005) and a heated debate on the "missing" $\mathrm{CH}_{4}$ source started. First, underestimated soil wetland emissions (Melack \& Hess 2009) were thought to account for the increased $\mathrm{CH}_{4}$ concentrations. Later, Keppler et al. (2006) found out that plants are able to produce $\mathrm{CH}_{4}$ through a novel aerobic pathway and suggested that about half of the global $\mathrm{CH}_{4}$ emissions were plant-derived. However, other researchers failed to replicate Keppler's study (Beerling et al. 2008, Dueck et al. 2007, Nisbet et al. 2009). Consequently, tropical wetlands were back into focus.

$\mathrm{CH}_{4}$ emissions from "canopy wetlands" that are described in this dissertation are unique. For the first time, $\mathrm{CH}_{4}$ emissions from bromeliad tanks, growing in the forest canopy, were studied.

The results showed that bromeliad tanks contribute substantially to $\mathrm{CH}_{4}$ emissions from neotropical forests. In the bromeliad tanks a diverse methanogenic community was found capable of producing $\mathrm{CH}_{4}$. The results of a ${ }^{13} \mathrm{CH}_{4}$ tracer experiment in the lab suggested that the produced methane in the tank was uptake by the bromeliad leaves through foliar trichomes, diffused into aerenchyma and emitted through stomata into the atmosphere. $\mathrm{CH}_{4}$ emitted from plants, other than tank bromeliads, is produced either by chemical degradation of plant pectin (Keppler et al. 2006, Keppler et al. 2008) or in anoxic microsites in the soil and diffused only by plant organs (Joabsson et al. 1999, Nisbet et al. 2009). $\mathrm{CH}_{4}$ from bromeliad tanks differs fundamentally in that it is produced above ground in the "canopy wetlands". There were no differences between $\mathrm{CH}_{4}$ emissions of different tank bromeliad species. However, based on plant architecture and ecological niche preferences, three functional types of tank bromeliads were distinguished and each bromeliad functional type showed an exponential relationship between $\mathrm{CH}_{4}$ emission rates and tank diameters and water content. Furthermore, there 
were differences between the bromeliad functional types. Consequently, canopy location of the tank bromeliad explains $\mathrm{CH}_{4}$ emissions more than tank bromeliad species. Tank bromeliad functional type II and III tended to show higher $\mathrm{CH}_{4}$ emissions per tank diameter than type I. Type II and III are common in the mid- and especially over-storey, while type I is common in the understory and growing even non-epiphytically on the ground. Type II and III are more robust plants than type I and store more water and leaf litter creating a more anoxic tank habitat with a bigger amount of substrate in the tank, ideal for methanogenic archaea. Furthermore, type I tank bromeliads could be inhabited by a greater amount of methanotrophic bacteria, since they are almost growing on the soil, where methanotrophic bacteria are predominant. However, there is no study on methanogenic archaea in bromeliads. Therefore, further research has to reveal interdependencies between methanogenic archae and other microorganisms and between their host, the tank bromeliad.

The $\mathrm{CH}_{4}$ emissions from tank bromeliads were extrapolated from the $2000 \mathrm{~m}$ elevation site to the whole neotropical forest and is about $1.2 \mathrm{Tg} \mathrm{CH}_{4} \mathrm{yr}^{-1}$. This in turn is about $3.2 \%$ to $30 \%$ of the estimated total missing $\mathrm{CH}_{4}$ source over neotropical forests (do Carmo et al. 2006). Extrapolation of $\mathrm{CH}_{4}$ emissions from this small-scale study to larger spatial and temporal scales is very difficult and challenging because the mechanisms of $\mathrm{CH}_{4}$ production and their dependency on other factors (e.g. tank bromeliad species, functional type, substrate in the tank) in the tanks of bromeliads are mainly unknown. Furthermore, there are only few estimates of bromeliad densities in the neotropics and appear to be lower in lowland forests than in montane forests. 


\section{NUTRIENT CONTROLS ON BIOGEOCHEMICAL CYCLES IN TROPICAL MONTANE FOREST ECOSYSTEMS}

The prediction of climate and environmental change effects on the biogeochemistry of tropical montane forest ecosystems is of great importance for developing future climate change scenarios because tropical montane forest ecosystems store more soil C per unit area than tropical lowland forests (Girardin et al. 2010) and are also "global biodiversity hot spots" (Myers et al. 2000). They are one of the least studied tropical forest ecosystems because of their difficult accessibility and their huge heterogeneity in biotic and abiotic controls over biogeochemical cycling. Due to this heterogeneity, multiple nutrient limitations that are not only restricted to plant growth (Sterner \& Elser 2002) may occur in tropical montane forest ecosystems and may create an extraordinary coupling of biogeochemical cycles in contrast to other forest ecosystems. Nutrient controls on the $\mathrm{C}$ and $\mathrm{N}$ cycle in tropical forest ecosystems are of increasing interest to the scientific community not least because of projected increases in atmospheric $\mathrm{N}$ deposition in tropical regions (Galloway et al. 2008). Terrestrial C and $\mathrm{N}$ cycles are linked through ecosystem processes such as photosynthesis and biomass growth. Therefore, many predictions on how future climate and environmental changes will affect $\mathrm{C}$ and $\mathrm{N}$ cycling base on observed changes in above and belowground plant components. Since multiple nutrient limitations of various components of the ecosystem may occur in tropical montane forests, the effects of projected increases in atmospheric $\mathrm{N}$ deposition on the $\mathrm{C}$ and $\mathrm{N}$ cycle in tropical montane forests may differ from other forest ecosystems in that it not only depend on nutrient limitation of vegetation growth but also on nutrient limitations of decomposition and other ecosystem processes. 


\section{NUTRIENT CONTROLS ON SOIL NITROGEN CYCLING AND NITROUS OXIDE FLUXES}

Natural tropical soils are the major natural source of $\mathrm{N}_{2} \mathrm{O}$ (IPCC 2007). Tropical montane forest are one of the least studied tropical forest ecosystems on earth and most studies on $\mathrm{N}_{2} \mathrm{O}$ fluxes in tropical forests are heavily biased toward lowland tropical forests (Purbopuspito et al. 2006). It is assumed that rates of soil $\mathrm{N}$ cycling and $\mathrm{N}_{2} \mathrm{O}$ emissions are predictable from nutrient limitation of vegetation growth (Hall \& Matson 2003). Tropical montane forests are thought to be $\mathrm{N}$ limited or simultaneously $\mathrm{N}$ and $\mathrm{P}$ limited (Tanner et al. 1998) and are characterized by small rates of soil $\mathrm{N}$ cycling and $\mathrm{N}$ losses (Koehler et al. 2009). However, there are observations that contradict this hypothesis suggesting that rates of soil $\mathrm{N}$ cycling and $\mathrm{N}$ losses are predictable by soil properties and by the presence of an organic layer rather than by nutrient limitation of vegetation growth (Corre et al. 2010).

Our results from the nutrient manipulation experiment in the tropical montane forest of Southern Ecuador that are described in this dissertation are unique. For the first time, nutrient controls on rates of soil $\mathrm{N}$ cycling and soil $\mathrm{N}_{2} \mathrm{O}$ fluxes along an elevation gradient in tropical montane forest ecosystems of Southern Ecuador, a top global biodiversity hotspot, were studied.

The results showed that independent from nutrient limitation of vegetation growth, soil nitrogen cycling and by extension soil $\mathrm{N}_{2} \mathrm{O}$ emissions may primarily be controlled by nutrient limitations of decomposition processes in the soil. Although nutrient limitation of vegetation growth varied among elevation, addition of $\mathrm{N}$ or $\mathrm{N}+\mathrm{P}$ always stimulated rates of soil $\mathrm{N}$ cycling and/or $\mathrm{N}_{2} \mathrm{O}$ emissions but $\mathrm{P}$ alone had almost no effect. Furthermore, nutrient addition effects decreased with elevation. In contrast to tropical lowland forests, tropical montane forests exhibit low temperatures that may limit decomposition processes and thus soil $\mathrm{N}$ cycling processes and have likely damped nutrient addition effects. In other words, the quantity of nutrients applied in this nutrient addition experiment was insufficient to overcome temperature limitation or 
was constrained by temperature limitation at higher elevations. However, the relatively strong effects of $\mathrm{N}$ addition on soil $\mathrm{N}$ cycling and $\mathrm{N}_{2} \mathrm{O}$ emissions are surprising, since the amount of nitrogen added in our nutrient manipulation experiment was lower than compared to other nutrient manipulation experiments in tropical montane forests (Hall \& Matson, 2003; Köhler et al. 2009). Hence, the magnitude and timing of $\mathrm{N}_{2} \mathrm{O}$ emissions depend on the interplay between the nutrient status of the forest soil and the amount of nutrient added.

These observations contradict the hypothesis of Hall \& Matson (2003) and support the assumption of Corre et al. (2010) who stated that soil properties have to be taken into account to predict $\mathrm{N}$-addition effects on rates of $\mathrm{N}$ cycling and $\mathrm{N}_{2} \mathrm{O}$ fluxes in tropical forest soils. This assumption is in line with the finding of Kaspari et al. (2008) who found out that litter decomposition processes can be limited by multiple nutrients. Hence, rates of $\mathrm{N}$ - and other nutrient cycling processes are mainly determined by the interplay of multipe nutrient limitations in the soil. However, there are several factors that have to be taken into account when identifying nutrient limitation. 1) There can be simultaneous limitation by multiple resources (e.g. nutrients, photsynthetically active radiation, water, $\mathrm{CO}_{2}$ ) (Field et al., 1992). 2) Kaspari et al. (2008) suggest that tropical forests are a nonLiebig world, where multiple nutrient limitations occur. 3) Hedin et al. (2009) emphasizes that forest compartments (e.g. canopy, trees, roots, soil) can have different nutrient limitation, simultaneously. Even within a species, individuals can have different nutrient limitation (Tanner et al. 1998). 4) Probably, the most challenging question is how nutrient cycles and thus nutrient limitation vary in space and time (Hedin et al., 2009).

This interplay between multiple nutrient limitations in the soil may explain why primary production rates, nutrient cycling and $\mathrm{N}_{2} \mathrm{O}$ fluxes differ very much between tropical forests on different soils.

Our results show that tropical montane forests with thick organic layers may respond to projected increases in atmospheric $\mathrm{N}$ deposition with immediate increases in soil $\mathrm{N}_{2} \mathrm{O}$ emissions but it remains to be seen how fast rates soil $\mathrm{N}$ cycling and soil $\mathrm{N}_{2} \mathrm{O}$ 
emissions will increase following further $\mathrm{N}$ additions. Therefore, future research has to focus on long term $\mathrm{N}$-addition effects on gross rates of $\mathrm{N}$ mineralization and nitrification to identify quantitative changes in the microbial $\mathrm{N}$ cycling and associated $\mathrm{N}_{2} \mathrm{O}$ emissions.

\section{NUTRIENT CONTROLS ON SOIL RESPIRATION}

The increase of soil respiration following $\mathrm{N}$ addition at the 2000-m and 3000-m site in our study area supports the general assumption that not only nutrient limitation of vegetation growth but also nutrient limitations of other ecosystem processes may play an important role in determining nutrient-addition effects on biogeochemical processes in tropical montane forest ecosystems. Vegetation growth at the two higher elevation sites tended to be $\mathrm{N}+\mathrm{P}$ limited but addition of the respective nutrients in combination failed to affect soil respiration. In contrast, addition of $\mathrm{N}$ alone stimulated soil respiration at the higher elevation sites. Our results may indicate that addition of $\mathrm{N}+\mathrm{P}$ may have stimulated microbial activity in the organic layer but at the same time plant available $\mathrm{N}$ and $\mathrm{P}$ increased and induced a shift in $\mathrm{C}$ partitioning from below to aboveground along with a reduction of root respiration. Hence, soil respiration did not change. In contrast, addition of $\mathrm{N}$ alone stimulated heterotrophic respiration but failed to affect vegetation growth and root respiration because vegetations demand for $\mathrm{P}$ was not fulfilled. Hence, soil respiration increased. Our results contrast the general suggestion that $\mathrm{N}$ addition decreases decomposition rates and heterotrophic respiration and stimulates accumulation of organic matter (Hyvonen et al. 2007, Janssens et al. 2010). However, thick organic layers that can also be found in boreal forest may indicate multiple nutrient limitations in the decomposition process. In such severely nutrient limited forests, microbial activity may increase following $\mathrm{N}$ addition (Janssens et al. 2010). The exact mechanism behind $\mathrm{N}$-addition effects on heterotrophic respiration is unclear but the main regulating factor of heterotrophic respiration is suggested to be the activity of enzymes in the decomposition process (Carreiro et al. 2000). In N limited 
forests, the decomposition of cellulose accelerates following $\mathrm{N}$ addition (Keeler et al. 2009) and may stimulate heterotrophic respiration. However, $\mathrm{N}$ addition is also suggested to decrease decomposition of lignin following $\mathrm{N}$ addition in $\mathrm{N}$ limited forests. Since the lignin matrix in leaflitter contains substrates that are easily decomposable (Fog 1988), the degradation of these substrates also decrease. Consequently, the total rate of decomposition decreases (DeForest et al. 2004). It may be very important to straighten these processes in time. Decreases in microbial activity and heterotrophic respiration were observed more often in studies of longer duration and where higher amounts of $\mathrm{N}$ was added (Knorr et al. 2005, Treseder 2008), while low amounts of added $\mathrm{N}$ stimulated decomposition rates (Knorr et al. 2005). Hence, the moderate amounts of $\mathrm{N}$ added in our nutrient manipulation experiment may have been sufficient to increase heterotrophic respiration in the organic layer by stimulating cellulosedecomposing enzymes but it remains to be seen whether further $\mathrm{N}$ addition will lead to a suppression of lignin-decomposing microbes by cellulose-decomposing microbes (Agren et al. 2001) and result in a net decrease of microbial activity, decomposition, heterotrophic respiration and soil respiration.

Our results show that tropical montane forests with thick organic layers may respond to projected increases in atmospheric $\mathrm{N}$ deposition with immediate increases in soil respiration. If we take the huge tropical montane forest area into account, projected increases in atmospheric $\mathrm{N}$ deposition in tropical regions may have the potential for a substantial loss of $\mathrm{C}$ stocks in tropical montane forests. Therefore, future research has to focus on measurements of microbial biomass, rates of decomposition and of heterotrophic and autotrophic respiration and their responses to nutrient additions in these forest ecosystems to reveal the mechanisms behind the immediate stimulation of soil respiration. 


\section{REFERENCES}

Agren, G. I., E. Bosatta, and A. H. Magill. 2001. Combining theory and experiment to understand effects of inorganic nitrogen on litter decomposition. Oecologia 128:94-98.

Beerling, D. J., T. Gardiner, G. Leggett, A. McLeod, and W. P. Quick. 2008. Missing methane emissions from leaves of terrestrial plants. Global Change Biology 14:1821-1826.

Carreiro, M. M., R. L. Sinsabaugh, D. A. Repert, and D. F. Parkhurst. 2000. Microbial enzyme shifts explain litter decay responses to simulated nitrogen deposition. Ecology 81:2359-2365.

Corre, M. D., E. Veldkamp, J. Arnold, and S. J. Wright. 2010. Impact of elevated N input on soil $\mathrm{N}$ cycling and losses in old-growth lowland and montane forests in Panama. Ecology 91:1715-1729.

DeForest, J. L., D. R. Zak, K. S. Pregitzer, and A. J. Burton. 2004. Atmospheric nitrate deposition and the microbial degradation of cellobiose and vanillin in a northern hardwood forest. Soil Biology \& Biochemistry 36:965-971.

do Carmo, J. B., M. Keller, J. D. Dias, P. B. de Camargo, and P. Crill. 2006. A source of methane from upland forests in the Brazilian Amazon. Geophysical Research Letters 33.

Dueck, T. A., R. de Visser, H. Poorter, S. Persijn, A. Gorissen, W. de Visser, A. Schapendonk, J. Verhagen, J. Snel, F. J. M. Harren, A. K. Y. Ngai, F. Verstappen, H. Bouwmeester, L. Voesenek, and A. van der Werf. 2007. No evidence for substantial aerobic methane emission by terrestrial plants: a C-13-labelling approach. New Phytologist 175:29-35. 
Field, C. B., F. S. Chapin, P. A. Matson, and H. A. Mooney. 1992. Responses of terrestrial ecosystems to the changing atmosphere - a resource-based approach. Annual Review of Ecology and Systematics 23:201-235.

Fog, K. 1988. The effect of added nitrogen on the rate of decomposition of organicmatter. Biological Reviews of the Cambridge Philosophical Society 63:433-462.

Frankenberg, C., J. F. Meirink, M. van Weele, U. Platt, and T. Wagner. 2005. Assessing methane emissions from global space-borne observations. 308:1010-1014.

Galloway, J. N., A. R. Townsend, J. W. Erisman, M. Bekunda, Z. C. Cai, J. R. Freney, L. A. Martinelli, S. P. Seitzinger, and M. A. Sutton. 2008. Transformation of the nitrogen cycle: Recent trends, questions, and potential solutions. 320:889-892.

Girardin, C. A. J., Y. Malhi, L. E. O. C. Aragao, M. Mamani, W. H. Huasco, L. Durand, K. J. Feeley, J. Rapp, J. E. Silva-Espejo, M. Silman, N. Salinas, and R. J. Whittaker. 2010. Net primary productivity allocation and cycling of carbon along a tropical forest elevational transect in the Peruvian Andes. Global Change Biology 16:3176-3192.

Hall, S. J., and P. A. Matson. 2003. Nutrient status of tropical rain forests influences soil N dynamics after N additions. Ecological Monographs 73:107-129.

Hyvonen, R., G. I. Agren, S. Linder, T. Persson, M. F. Cotrufo, A. Ekblad, M. Freeman, A. Grelle, I. A. Janssens, P. G. Jarvis, S. Kellomaki, A. Lindroth, D. Loustau, T. Lundmark, R. J. Norby, R. Oren, K. Pilegaard, M. G. Ryan, B. D. Sigurdsson, M. Stromgren, M. van Oijen, and G. Wallin. 2007. The likely impact of elevated [ $\left.\mathrm{CO}_{2}\right]$, nitrogen deposition, increased temperature and management on carbon sequestration in temperate and boreal forest ecosystems: a literature review. New Phytologist 173:463-480.

IPCC. Climate Change 2007: The Physical Science Basis. Contribution of Working Group I to the Fourth Assessment Report of the Intergovernmental Panel on Climate Change. Solomon, S., Manning, M., Chen, Z., Marquis, M., Averyt, K. B., Tignor, M., 
and Miller, H. L. 2007. Cambridge University Press, Cambridge, United Kingdom and New York, USA.

Janssens, I. A., W. Dieleman, S. Luyssaert, J. A. Subke, M. Reichstein, R. Ceulemans, P. Ciais, A. J. Dolman, J. Grace, G. Matteucci, D. Papale, S. L. Piao, E. D. Schulze, J. Tang, and B. E. Law. 2010. Reduction of forest soil respiration in response to nitrogen deposition. Nature Geoscience 3:315-322.

Joabsson, A., T. R. Christensen, and B. Wallen. 1999. Vascular plant controls on methane emissions from northern peatforming wetlands. Trends in Ecology \& Evolution 14:385-388.

Kaspari, M., M. N. Garcia, K. E. Harms, M. Santana, S. J. Wright, and J. B. Yavitt. 2008. Multiple nutrients limit litterfall and decomposition in a tropical forest. Ecology Letters 11:35-43.

Keeler, B. L., S. E. Hobbie, and L. E. Kellogg. 2009. Effects of long-term nitrogen addition on microbial enzyme activity in eight forested and grassland sites: Implications for litter and soil organic matter secomposition. Ecosystems 12:1-15.

Keppler, F., J. T. G. Hamilton, M. Brass, and T. Rockmann. 2006. Methane emissions from terrestrial plants under aerobic conditions. Nature 439:187-191.

Keppler, F., J. T. G. Hamilton, W. C. McRoberts, I. Vigano, M. Brass, and T. Rockmann. 2008. Methoxyl groups of plant pectin as a precursor of atmospheric methane: evidence from deuterium labelling studies. New Phytol. 178:808-814.

Knorr, M., S. D. Frey, and P. S. Curtis. 2005. Nitrogen additions and litter decomposition: A meta-analysis. Ecology 86:3252-3257.

Koehler, B., M. D. Corre, E. Veldkamp, H. Wullaert, and S. J. Wright. 2009. Immediate and long-term nitrogen oxide emissions from tropical forest soils exposed to elevated nitrogen input. Global Change Biology 15:2049-2066. 
Melack, J. M., and L. L. Hess. 2009. Remote sensing of the distribution and extent of wetlands in the Amazon basin. in W. J. Junk, and M. Piedade editors. Amazonian floodplain forests: Ecophysiology, ecology, biodiversity and sustainable management. Springer, New York.

Myers, N., R. A. Mittermaier, C. G. Mittermaier, G. A. B. Fonseca, and J. Kent. 2000. Biodiversity hotspots for conservation priorities. Nature 403:853-858.

Nisbet, R. E. R., R. Fisher, R. H. Nimmo, D. S. Bendall, P. M. Crill, A. V. Gallego-Sala, E. R. C. Hornibrook, E. Lopez-Juez, D. Lowry, P. B. R. Nisbet, E. F. Shuckburgh, S. Sriskantharajah, C. J. Howe, and E. G. Nisbet. 2009. Emission of methane from plants. Philosophical Transactions of the Royal Society of London Series BBiological Sciences 276:1347-1354.

Purbopuspito, J., E. Veldkamp, R. Brumme, and D. Murdiyarso. 2006. Trace gas fluxes and nitrogen cycling along an elevation sequence of tropical montane forests in Central Sulawesi, Indonesia. Global Biogeochemical Cycles 20.

Sterner R. W., and J. J. Elser. 2002. Ecological stoichiometry: the biology of elements from molecules to the biosphere. Princeton University Press, Princeton, NJ, USA.

Tanner, E. V. J., P. M. Vitousek, and E. Cuevas. 1998. Experimental investigation of nutrient limitation of forest growth on wet tropical mountains. Ecology 79:10-22.

Treseder, K. K. 2008. Nitrogen additions and microbial biomass: A meta-analysis of ecosystem studies. Ecology Letters 11:1111-1120. 


\section{ACKNOWLEDGEMENTS}

Neues, bisher Unbekanntes zu entdecken, sei es im Alltag beim Spielen mit meinem Sohn, beim Küchenabwasch oder bei meiner Forschungsarbeit hat mich stets motiviert. Der Weg ist manchmal einfach aber manchmal auch steinig und mühsam. Doch man geht ihn nie allein. Das Promotionsprojekt hat mir die Möglichkeit gegeben, in eines der unbekanntesten Ökosysteme der Erde vorzudringen und nach Neuem zu suchen. Viele Menschen haben mir in diesem Projekt geholfen und mich nachhaltig beeinflusst. Zuallererst möchte ich Herrn Prof. Edzo Veldkamp danken. Als Doktorvater hat er mich seit meiner Bachelorarbeit betreut. Er hat mich stets großartig motiviert und mir die entscheidenden Impulse während meines Projekts gegeben.

Ich möchte Herrn Prof. Heiner Flessa danken. Mit seiner Vorlesung in der Bodenkunde während meines Studiums hat er in mir die Faszination für die Stoffkreisläufe in Ökosystemen geweckt.

Dr. Marife D. Corre, meiner Zweitbetreuerin, möchte ich für die große Hilfe und den vielen anregenden Diskussionen danken.

Der Deutschen Forschungsgemeinschaft und insbesondere der DFG-Forschergruppe 816 möchte ich für die Finanzierung des Projekts und die tolle Unterstützung danken.

Des Weiteren möchte ich meiner Kollegin Katrin Wolf danken. Viele der schwierigen Situationen während der Promotionsarbeit konnte ich nur mit Ihrer Hilfe bewältigen.

Katrin Wolf, Oliver van Straaten, Dr. Marife Corre, Dr. Christoph Scherber, Dr. Florian Werner, Prof. Dr. Ralph Conrad, Dr. Jürgen Homeier, Prof. S. Robbert Gradstein, Dr. Josh B. Fisher, Boris M. Hillmann und Jason Dittmann möchte ich für die Hilfe und den vielen wissenschaftlichen Diskussionen danken.

Herrn Dr. Michael Schwertfeger, wissenschaftlicher Leiter des Alten Botanischen Gartens in Göttingen, möchte ich für Bereitstellung zahlreicher Bromelien für die Experimente in meiner Promotionsarbeit danken.

Herrn Prof. Ralph Conrad und Melanie Klose vom Max-Planck Institut für Terrestrische Mikrobiologie in Marburg möchte ich dafür danken, dass sie mir immer jede erdenkliche Hilfe im Rahmen des Bromelien-Projekts schnell zukommen ließen. Ohne Ihre Hilfe, hätte ich das Tankbromlien-Projekt nie so erfolgreich zum Abschluss bringen können. Herrn Prof. Ralph Conrad danke ich darüber hinaus für die spannende Einführung in die Mikrobiologie.

Meinen Eltern möchte ich am allermeisten danken. Trotz schwierigster Situationen haben sie mich stets unterstützt und an mich geglaubt. Sie sind meine größten Vorbilder.

Schließlich möchte ich meiner Frau Tina und meinem Sohn Frederik danken. Sie haben immer zu mir gehalten und mich unterstützt, obwohl ich es Ihnen nicht immer leicht gemacht habe. 


\section{DECLARATION OF ORIGINALITY AND CERTIFICATE OF OWNERSHIP}

I, Guntars O. Martinson, hereby declare that I am the sole author of this dissertation entitled "Trace Gas Fluxes from Tropical Montane Forests of Southern Ecuador". All references and data sources that were used in this dissertation have been appropriately acknowledged. I furthermore declare that this work has not been submitted elsewhere in any form as part of another dissertation procedure.

Chapter 2: Ralph Conrad and Melanie Klose analysed molecular data. Florian Werner identified tank bromeliads and estimated bromeliad densities. Christoph Scherber did major parts of statistical analysis.

Chapter 3+4: Jürgen Homeier provided data on aboveground litterfall, litterfall nutrient contents and information on forest structure and characteristics.

Goettingen, March 7, 2011

(Guntars 0. Martinson) 


\section{CURRICULUM ViTAE}

\section{$\underline{\text { Personal Details }}$}

Date of Birth: $\quad 8.10 .1980$

Place of Birth: $\quad$ Bonn Bad Godesberg, Germany

Nationality German

\section{$\underline{\text { University Education }}$}

06. 2007 - 03.2011 Georg-August University of Goettingen, Germany

Ph.D. student at the Faculty of Forest Sciences and Forest Ecology,

Department of Soil Science of Tropical and Subtropical Ecosystems

10. 2005 - 04.2007 Georg-August University of Goettingen, Germany

Master of Science in Tropical and International Forestry

10. 2001 - 08.2005 Georg-August University of Goettingen, Germany

Bachelor of Science in Forest Sciences and Forest Ecology

\section{$\underline{\text { Research Experience }}$}

11. 2010 - ongoing Postdoctoral fellow at the Max-Planck institute for Terrestrial Microbiology, Marburg, Germany

06. 2007 - 03.2011 PhD student at the Buesgen Institute, Department of Soil Science of Tropical and Subtropical Ecosystems, Georg-August University of Goettingen, Germany

01. 2007 - 03.2007 Visiting Research Assistant at the Department of Plant Science, University of California, Davis, USA

05. 2004 - 01.2007 Research Assistant (intermittent) at the Buesgen Institute, Department of Soil Science of Tropical and Subtropical Ecosystems and at the Department of Soil Science of Temperate and Boreal Ecosystems of the Georg-August University of Goettingen, Germany 


\section{LIST OF PUBLICATIONS, REPORTS}

\section{Peer Reviewed Publications}

K. Wolf, E. Veldkamp, J. Homeier, G.0. Martinson (2011). Nitrogen availability links forest productivity, soil nitrous oxide and nitric oxide fluxes of a tropical montane forest in Southern Ecuador. Global Biogeochemical Cycles, (doi, 10.1029/2010GB003876)

G.0. Martinson, F.A. Werner, C. Scherber, R. Conrad, E. Veldkamp, H. Flessa, K. Wolf, M.D. Corre, M. Klose and S.R. Gradstein (2010). Tank Bromeliads: Methane producing 'canopy wetlands' in neotropical forests. Nature Geoscience, 3, 766-769.

Paul, S., G.O. Martinson, E. Veldkamp, H. Flessa (2008). Sample pre-treatment affects the distribution of organic carbon in aggregate fractions of tropical grassland soils. Soil Science Society of America Journal, 72, 500-506.

\section{Reports (press released and non-peer-reviewed publications)}

G.O. Martinson (2011). Methane Emissions from Canopy Wetlands. Report in iLeaps Newsletter. Issue No. 11.

G.0. Martinson (2011). "Canopy wetlands": A novel Source of Methane. Report in Science News of the TMF Newsletter of the DFG Research Unit 816. Issue No. 11.

G.0. Martinson \& N. Alig (2006). Soil Investigation in the Eastern Mountainous Border of the Nam Ton Watershed, Lao PDR. Technical report for the "German Technical Cooperation (GTZ) and the "Mekong River Commission (MRC)"

G.0. Martinson \& N. Alig (2006). Impact of different land-use systems on water-related issues: Grassland vs. Forest plantation. Technical report for the "German Technical Cooperation (GTZ) and the "Mekong River Commission (MRC)" 